\title{
Estudos termoanalíticos dos edulcorantes acessulfame-K, aspartame, ciclamato, esteviosídeo e sacarina
}

Dissertação apresentada ao Instituto de Química de São Carlos, da Universidade de São Paulo, como um dos requisitos para a obtenção do título de Mestre em Ciências (Química Analítica)

Orientador: Prof. Dr. Éder Tadeu Gomes Cavalheiro

São Carlos

2007 


Aos meus pais, Delci e
Marlene, por todo amor,
carinho, apoio e incentivo aos
meus estudos. Aos meus irmãos
Daniele e Marco Antônio pela
amizade. À linda Sofia por
alegrar minha vida e também à
Cristiane. Ao André Luís pelo
companheirismo, carinho e
compreensão durante todo este
periodo.


Ao Prof. Dr. Éder T. G. Cavalheiro, pela orientação amizade e incentivo. 


\section{AGRADECIMENTOS}

Primeiramente, a Deus.

Ao Prof. Dr Orlando Fatibello Filho e a Dr. Karina Omuro Lupetti que me iniciaram na pesquisa científica, e por quem tenho muito carinho e admiração.

Ao Prof. Dr. Gilberto Chierice pela disponibilidade do laboratório.

Ao Luiz, pela paciência e ajuda no laboratório e também nos equipamentos sempre que precisei.

Aos amigos da análise térmica Milena, Isabel e Toni que muito ajudaram e contribuíram para a realização deste trabalho. E também ao Puff pelas várias ajudas no computador sempre com muita paciência.

Às meninas, Amanda, Carol, Grazi, Ivana, Juliana, Priscila e Rita pela amizade e pelas longas conversas.

Aos demais amigos do LATEQS e GQATP: Avaré, Royal, Felipe, Luciana (tia Lu), Érica, Sandra, Glimaldo, Braba, Bruno, Júnia, Erik, Paulo, Rafael, Toninho, Marli e Salvador.

Aos técnicos Augusto, Mauro e Silvana, pela disponibilidade e auxilio em diversas medidas.

Aos funcionários do IQSC, em especial Andréia e Sílvia, sempre muito prestativas.

Às minhas sempre amigas Michelli, Beth, Patrícia, Lúcia, lone e Catarine.

Ao IQSC pela oportunidade de realização deste projeto.

A todos que, de alguma forma, contribuíram para a realização deste trabalho. 


\section{RESUMO}

Neste trabalho, estudou-se a decomposição térmica dos edulcorantes não calóricos acessulfame-K, aspartame, ciclamato de sódio, esteviosídeo, sacarina e sacarina sódica de crescente uso na indústria alimentícia.

Para tanto, essas amostras foram submetidas à análise por TG, DTG DTA e DSC, após caracterização por análise elementar e por IV.

Após recristalização dos compostos comerciais ciclamato de sódio e sacarina sódica, observou-se nas curvas TG a presença de águas de hidratação. Nesta última, a primeira água é muito volátil e pode ser eliminada na secagem. 0 esteviosídeo apresentou umidade.

Os intermediários e os resíduos dos mesmos foram caracterizados por IV e quando necessário por difração de raios $X$. De maneira geral os compostos apresentaram decomposição com formação de resíduo carbonizado e geração de sulfato de potássio, no caso do acessulfame-K e sulfato de sódio na sacarina e ciclamato de sódio.

Estudos de cinética de decomposição em fase sólida foram realizados para o aspartame e sacarina, pois estes não apresentavam sobreposição de eventos. Os estudos cinéticos para decomposição térmica usando o método de Flynn-WallOzawa só puderam ser realizados para 0 aspartame resultando em $\log A=23,2 \pm 0,1 \mathrm{~min}^{-1}$ e $E_{a}=206,6 \pm 0,3 \mathrm{KJ} \mathrm{mol}^{-1}$. Os demais compostos apresentaram decomposição por eventos simultâneos, que dificultam os cálculos cinéticos.

A sacarina $H$ apresentou volatilização após fusão, com $E_{a}=154,9$ $\pm 0,7 \mathrm{KJ} \mathrm{mol}^{-1}$ e $\log A=15,2 \pm 0,1 \mathrm{~min}^{-1}$ 


\begin{abstract}
In this work the thermal decomposition of the non-caloric sweeteners acesulfame-K, aspartame, sodium ciclamate, stevioside, saccharine and sodium saccharine was performed.

Initially, the compounds were characterized usually elemental analysis and IR spectroscopy some were recrystallised from commercial samples, resulting in purified compounds.
\end{abstract}

After characterization the sweetener were analysed by TG/DTG, DTA and DSC.

The recrystallised compounds presented hydration water in aspartame and sodium saccharine. In the last the first water can be lost during drying, since it seems to be weakely bounded. Stevioside showed humidity water.

In a general way the sweeteners decomposes by a carbonaceous residue, and formed potassium sulfate as final residue in the acesulfame- $K$ case as well as sodium sulfate in sodium saccharine and sodium ciclamate.

Due to the overlapping of consecutive decomposition steps. The use o the Flynn-Wall-Ozawa method for kinetic calculations only could be performed for the decomposition of aspartame, resulting in $\log A=23,2 \pm 0,1 \mathrm{~min}^{-1}$ and $E_{a}=206,6$ $\pm 0,3 \mathrm{KJ} \mathrm{mol}^{-1}$. The volatilization of saccharine $\mathrm{H}$, after fusion, resulted in $E_{a}=154,9$ $\pm 0,7 \mathrm{KJ} \mathrm{mol}^{-1}$ and $\log \mathrm{A}=15,2 \pm 0,1 \mathrm{~min}^{-1}$. 


\section{LISTA DE FIGURAS}

Figura 1. Representação dos grupos funcionais (AH - B) de cada edulcorante (a) sacarina, (b) acessulfame, (c) ciclamato e (d) representação esquemática da interação entre o sítio receptor $\left(\mathrm{A}^{\prime} \mathrm{H}-\mathrm{B}^{\prime}\right)$ e o sítio doador $(\mathrm{AH}-\mathrm{B})$ do aspartame ${ }^{13}$

Figura 2. Ilustração das diferentes regiões da língua, receptores de sabor ${ }^{22}$

Figura 3. Espectros de absorção na região do infravermelho do ciclamato de sódio comercial e recristalizado

Figura 4. Espectro de absorção na região do infravermelho do ciclamato de sódio ${ }^{50}$

Figura 5. Espectro de absorção na região do infravermelho da sacarina sódica comercial e recristalizada

Figura 6. Espectro de absorção na região do infravermelho de sacarina sódica ${ }^{50}$

Figura 7. Espectro de absorção na região do infravermelho da sacarina

Figura 8. Espectro de absorção na região do infravermelho da sacarina ${ }^{50}$

Figura 9. Curvas TG/DTG (a) e TG/DTA (b) do acessulfame-K. obtidas sob atmosfera de ar para o acessulfame-K. Vazão de $100 \mathrm{~mL} \mathrm{~min}^{-1}$, massa de amostra de $4 \mathrm{mg}$, razão de aquecimento de $10 \stackrel{\circ}{\circ} \mathrm{C}$ $\min ^{-1}$ e suporte de amostra de alumina

Figura 10. Espectro de absorção na região infravermelho dos intermediários e do resíduo do acessulfame-K.

Figura 11. Difratograma de raios $\mathrm{X}$ do resíduo de acessulfame-K a $700 \stackrel{\circ}{ } \mathrm{C}$

Figura 12. Curvas TG/DTG (a) e TG/DTA (b)do aspartame obtidas sob atmosfera de ar. Vazão de $100 \mathrm{~mL} \mathrm{~min}^{-1}$, massa de amostra de $4 \mathrm{mg}$, razão de aquecimento de $10{ }^{\circ} \mathrm{C} \mathrm{min}^{-1}$ e suporte de amostra de alumina.

Figura 13. Espectros de absorção na região infravermelho dos resíduos de aspartame em diferentes temperaturas.

Figura 14. Espectro de absorbância na região do infravermelho da fenilalanina ${ }^{50}$

Figura 15. Difratograma de raios $X$ do resíduo de aspartame a $200{ }^{\circ} \mathrm{C}$

Figura 16. Curvas TG/DTG (a) e TG/DTA (b) do ciclamato de sódio comercial obtidas sob atmosfera de ar. Vazão de $100 \mathrm{~mL} \mathrm{~min}^{-1}$, massa de amostra de $4 \mathrm{mg}$, razão de aquecimento de $10^{\circ} \mathrm{C} \mathrm{min}^{-1} \mathrm{e}$ suporte de amostra de alumina.

Figura 17. Curvas TG/DTG (a), TG e DTA (b) do ciclamato de sódio recristalizado obtidas sob atmosfera de ar. Vazão de $100 \mathrm{~mL} \mathrm{~min}^{-1}$, massa de amostra de $4 \mathrm{mg}$, razão de aquecimento de $10 \stackrel{\circ}{\circ} \mathrm{C}$ $\min ^{-1}$ e suporte de amostra de alumina

Figura 18. Espectros de absorção na região do infravermelho dos resíduos de ciclamato de sódio comercial e recristalizado em diferentes temperaturas.

Figura 19. Difratograma de raios $\mathrm{X}$ do resíduo de ciclamato de sódio comercial a $330^{\circ} \mathrm{C}$

Figura 20. Difratograma de raios $\mathrm{X}$ do resíduo de ciclamato de sódio comercial a $660{ }^{\circ} \mathrm{C}$ 
Figura 21. Curvas TG/DTG (a), TG/DTA (b) do esteviosídeo obtidas sob atmosfera de ar. Vazão de $100 \mathrm{~mL} \mathrm{~min}^{-1}$, massa de amostra de $4 \mathrm{mg}$, razão de aquecimento de $10^{\circ} \mathrm{C} \mathrm{min}^{-1}$ e suporte de amostra de alumina

Figura 22. Espectros de absorção na região do infravermelho dos resíduos de esteviosídeo em diferentes temperaturas

Figura 23. Curvas TG e DTG, TG e DTA da sacarina $\mathrm{H}$ obtidas sob atmosfera de ar. Vazão de 100 $\mathrm{mL} \mathrm{min}^{-1}$, massa de amostra de $4 \mathrm{mg}$, razão de aquecimento de $10{ }^{\circ} \mathrm{C} \mathrm{min}^{-1}$ e suporte de amostra de alumina

Figura 24. Espectros de absorção na região do infravermelho dos cristais presentes no tubo de ensaio com amostra de sacarina após aquecimento (aproximadamente $\left.230^{\circ} \mathrm{C}\right)$

Figura 25. Curvas TG e DTG (a), TG e DTA (b) da sacarina sódica comercial obtida sob atmosfera de ar. Vazão de $100 \mathrm{~mL} \mathrm{~min}{ }^{-1}$, massa de amostra de $4 \mathrm{mg}$, razão de aquecimento de $10{ }^{\circ} \mathrm{C} \mathrm{min}^{-1} \mathrm{e}$ suporte de amostra de alumina.

Figura 26. Curvas TG e DTG (a), TG e DTA (b) da sacarina sódica recristalizada obtidas sob atmosfera de ar. Vazão de $100 \mathrm{~mL} \mathrm{~min}^{-1}$, massa de amostra de $4 \mathrm{mg}$, razão de aquecimento de $10 \stackrel{\circ}{\circ} \mathrm{C}$ $\min ^{-1}$ e suporte de amostra de alumina

Figura 27. Espectros de absorção na região do infravermelho dos resíduos de sacarina sódica comercial em diferentes temperaturas e de sulfato de sódio $\left(\mathrm{Na}_{2} \mathrm{SO}_{4} 20444-7\right.$ Aldrich FT-IR) ${ }^{49}$

Figura 28. Espectros de absorção na região do infravermelho dos resíduos de sacarina sódica recristalizada em diferentes temperaturas e de sulfato de sódio $\left(\mathrm{Na}_{2} \mathrm{SO}_{4} \text { 20444-7 Aldrich FT-IR }\right)^{49}$

Figura 29. Difratograma de raios $\mathrm{X}$ do resíduo de sacarina sódica comercial a $750{ }^{\circ} \mathrm{C}$

Figura 30. Curvas DSC obtidas sob atmosfera dinâmica de $\mathrm{N}_{2}$ com vazão de $100 \mathrm{~mL} \mathrm{~min}^{-1}$ para os edulcorantes acessulfame-K, aspartame, ciclamato de sódio comercial e recristalizado, esteviosídeo, sacarina, sacarina sódica comercial e recristalizada. Massa de amostra de $3 \mathrm{mg}$, razão de aquecimento de $10^{\circ} \mathrm{C} \mathrm{min}^{-1}$, inicial -70 a $130^{\circ} \mathrm{C}$, em suporte de amostra tampado de alumínio, com furo central

Figura 31. Curvas TG do aspartame obtidas a várias razões de aquecimento, sob atmosfera de $\mathrm{N}_{2}$, em suporte de alumina.

Figura 32. Logaritmo da razão de aquecimento em função do inverso da temperatura para os níveis de decomposição térmica fixados para o aspartame

Figura 33. Energia de ativação (Ea) vs fator de conversão $(\alpha)$ apresentados na Tabela 9 para o edulcorante aspartame

Figura 34. Curvas TG da sacarina $\mathrm{H}$ obtidas a várias razões de aquecimento, sob atmosfera de $\mathrm{N}_{2}$, em suporte de alumina

Figura 35. Logaritmo da razão de aquecimento em função do inverso da temperatura para os níveis de decomposição térmica fixados para a sacarina $\mathrm{H}$

Figura 36. Energia de ativação (Ea) vs fator de conversão $(\alpha)$ apresentados na Tabela 10 para o edulcorante sacarina 


\section{LISTA DE TABELAS}

Tabela 1. Comparação do poder adoçante de alguns edulcorantes em relação à sacarose ${ }^{5,6,10}$

Tabela 2. Teores de carbono $(C)$, hidrogênio $(H)$ e nitrogênio $(N)$ experimentais e calculados para os respectivos edulcorantes

Tabela 3. Atribuições de eventos térmicos, intervalos de temperatura e perdas de massa observados nas curvas TG/DTG do edulcorante acessulfame-K sob atmosfera de ar

Tabela 4. Atribuições de eventos térmicos, intervalos de temperatura e perdas de massa observados nas curvas TG/DTG do edulcorante aspartame sob atmosfera de ar

Tabela 5. Atribuições de eventos térmicos, intervalos de temperatura e perdas de massa observados nas curvas TG/DTG dos edulcorantes ciclamato de sódio comercial e recristalizado sob atmosfera de ar

Tabela 6. Atribuições de eventos térmicos, intervalos de temperatura e perdas de massa observados nas curvas TG/DTG do edulcorante esteviosídeo sob atmosfera de ar

Tabela 7. Atribuições de eventos térmicos, intervalos de temperatura e perdas de massa observados nas curvas TG/DTG do edulcorante sacarina (sacarina $\mathrm{H}$ ) sob atmosfera de ar

Tabela 8. Atribuições de eventos térmicos, intervalos de temperatura e perdas de massa observados nas curvas TG/DTG dos edulcorantes sacarina sódica comercial e recristalizado sob atmosfera de ar

70

Tabela 9. Parâmetros cinéticos de decomposição térmica do aspartame obtido para cada nível de conversão ( $T_{1 / 2} 60$ min - temperatura para meia vida de 60 minutos)

Tabela 10. Parâmetros cinéticos de decomposição térmica da sacarina obtida para cada nível de conversão ( $T_{1 / 2} 60$ min - temperatura para meia vida de 60 minutos) 


\section{SUMÁRIO}

1. INTRODUÇÃ̃O ERRO! INDICADOR NÃO DEFINIDO.

1.1 AdITIVOS ALIMENTARES ERRO! INDICADOR NÃO DEFINIDO. 1.2 EDULCORANTES .ERRO! INDICADOR NÃO DEFINIDO.

1.2.1 O que dá o sabor doce aos edulcorantes? Erro! Indicador não definido.

1.3 CONSIDERAÇÕES SOBRE AS TÉCNICAS A SEREM UTILIZADAS

1.3.1 Análise Térmica ERRO! INDICADOR NÃO DEFINIDO.

1.3.2 Análise Elementar $(A E)$ Erro! Indicador não definido.

1.3.3 Espectroscopia na Região do Infravermelho (IR). Erro! Indicador não definido.

1.3.4 Análise por Difração de raios $X(X R D)$ Erro! Indicador não definido.

1.3.5 Cinética de decomposição térmica Erro! Indicador não definido. Erro! Indicador não definido. 1.4 REVISÃO BIBLIOGRÁFICA . .ERRO! INDICADOR NÃO DEFINIDO.

2. OBJETIVOS ERRO! INDICADOR NÃO DEFINIDO.

\section{PROCEDIMENTO EXPERIMENTAI} ERRO! INDICADOR NÃO DEFINIDO.

3.1 REAGENTES E SOLUÇÕES ERRO! INDICADOR NÃO DEFINIDO.

3.2 RECRISTALIZAÇÃO DOS EDULCORANTES ERRO! INDICADOR NÃO DEFINIDO.

3.2.1 Recristalização do ciclamato de sódio e sacarina sódica. Erro! Indicador não definido.

3.2.2 Preparação da Sacarina Ácida. Erro! Indicador não definido.

3.3 CARACTERIZAÇÃO DOS EDULCORANTES POR ESPECTROSCOPIA NA REGIÃO DO INFRAVERMELHO (FT-IR)

ERRO! INDICADOR NÃO DEFINIDO.

3.4 CARACTERIZAÇÃo dOS COMPOSTOS POR ANÁLISE ELEMENTAR (EA) ... ERRO! INDICADOR NÃo DEFINIDO.

3.5 ESTUDOS TERMOANALÍTICOS ERRO! INDICADOR NÃO DEFINIDO.

3.5.1 Termogravimetria (TG), Termogravimetria Derivada (DTG) e Análise Térmica Diferencial (DTA)

Erro! Indicador não definido.

3.5.2 Calorimetria Exploratória Diferencial (DSC). Erro! Indicador não definido.

3.6 OBTENÇÃo E CARACTERIZAÇÃO DOS INTERMEDIÁRIOS E dOS RESÍDUOS DOS EDULCORANTES ........... ERRO! INDICADOR NÃO DEFINIDO.

3.7 CINÉTICA DE DECOMPOSIÇÃO TÉRMICA.

ERRO! INDICADOR NÃO DEFINIDO.

4. RESULTADOS E DISCUSSÃO ERRO! INDICADOR NÃO DEFINIDO.

4.1 RECRISTALIZAÇÃO DO CICLAMATO DE SÓDIO E SACARINA SÓDICA

ERRO! INDICADOR NÃO DEFINIDO.

4.1.1 Ciclamato de sódio Erro! Indicador não definido.

4.1.2 Sacarina Sódica ..... Erro! Indicador não definido. 4.2 PREPARAÇÃo DA SACARINA ÁCIDA .ERRO! INDICADOR NÃO DEFINIDO.

4.3 CARACTERIZAÇÃO DOS EDULCORANTES POR ANÁLISE ELEMENTAR (EA) . ERRO! INDICADOR NÃO DEFINIDO. 
4.4 ESTUDOS TERMOANALÍTICOS E CARACTERIZAÇÃO DE INTERMEDIÁRIOS E DOS RESÍDUOS DE CADA EDULCORANTE

ERRO! INDICADOR NÃO DEFINIDO.

4.4.1 Termogravimetria (TG), Termogravimetria Derivada (DTG) e Análise Térmica Diferencial (DTA) e sua respectiva caracterização

Erro! Indicador não definido.

4.5 CALORIMETRIA EXPLORATÓRIA DIFERENCIAL (DSC). .ERRO! INDICADOR NÃO DEFINIDO.

4.6 CINÉTICA DE DECOMPOSIÇÃO TÉRMICA. ERRO! INDICADOR NÃO DEFINIDO.

4.6.1 Aspartame Erro! Indicador não definido. 4.6.2 Sacarina Erro! Indicador não definido.

5. CONCLUSÕES .ERRO! INDICADOR NÃO DEFINIDO.

6. REFERÊNCIAS BIBLIOGRÁFICAS ERRO! INDICADOR NÃO DEFINIDO. 


\section{LISTA DE ABREVIATURAS E SIGLAS}

Análise Elementar

Análise por Difração de Raios X

(XRD)

Análise Térmica Diferencial

(DTA)

Calorimetria Exploratória Diferencial

(DSC)

Ciclamato de Sódio Comercial

(Ciclamato $\mathrm{Na}$ Com ou Ciclam $\mathrm{Na}$ Com)

Ciclamato de Sódio Recristalizado

(Ciclamato Na Rec ou Ciclam Na Rec)

Constante dos Gases

Decomposição

Energia de Ativação

Espectroscopia na Região do Infravermelho

Fator de Conversão

Fator Pré-Exponencial de Arrhenius

Função do Modelo Cinético

Material Carbonizado

(MC)

Razão de Aquecimento

Sacarina

(Sacarina H ou Sacarina Ácida)

Sacarina Sódica Comercial (Sacarina Na Com ou Sac Na Com)

Sacarina Sódica Recristalizada (Sacarina Na Rec ou Sac Na Rec)

Sulfato de Potássio $\left(\mathrm{K}_{2} \mathrm{SO}_{4}\right)$

Sulfato de Sódio $\left(\mathrm{Na}_{2} \mathrm{SO}_{4}\right)$

Temperatura

Termogravimetria

Termogravimetria Derivada

Velocidade de Reação

$(\mathrm{d} \alpha / \mathrm{dT})$ 


\section{INTRODUÇÃO}

\subsection{Aditivos Alimentares}

Os aditivos alimentares, são substâncias naturais ou sintéticas adicionadas intencionalmente aos alimentos visando melhorar ou prolongar sua conservação, melhora de aspecto, sabor, aroma, etc.; com o propósito de valorizá-los aumentando seu valor de mercado ou estendendo seu prazo de validade para consumo, sendo amplamente empregados na indústria alimentícia contemporânea ${ }^{1}$.

Os aditivos são classificados em diferentes grupos de acordo com sua finalidade, podendo ser corantes, flavorizantes, aromatizantes, conservadores, espessantes, edulcorantes, entre outros ${ }^{2}$. Em especial, os edulcorantes não calóricos, vem apresentando aumento significativo de consumo ${ }^{3}$, pois estão relacionados com o controle da obesidade e são consumidos tanto por questões de saúde, como por estética.

\subsection{Edulcorantes}

Segundo a ANVISA, os edulcorantes são substâncias diferentes dos açúcares, que também apresentam poder adoçante, em alguns casos muito superior ao da sacarose, como pode ser visto na Tabela $1^{4-6}$. São utilizados, principalmente, em produtos dietéticos destinados à alimentação de pessoas diabéticas e/ou obesas, bem como em produtos farmacêuticos, com o objetivo de mascarar características próprias de alguns princípios ativos, como por exemplo, o amargor. 
Além disso, alguns edulcorantes não nutritivos podem diminuir a incidência de cáries, uma vez que não são fontes de nutrientes para os microorganismos presentes na boca $^{7-9}$.

Tabela 1. Comparação do poder adoçante de alguns edulcorantes em relação à sacarose $e^{5,6,10}$

\begin{tabular}{|cc|}
\hline Edulcorantes & Poder adoçante $^{*}$ \\
\hline Acessulfame-K & $180-200$ \\
Aspartame & $180-200$ \\
Ciclamato & $30-40$ \\
Frutose & $1,2-1,7$ \\
Manitol & $0,7-1,4$ \\
Sacarina & $400-500$ \\
Esteviosídeo & 300 \\
\hline
\end{tabular}

*em relação à sacarose $=1$

Os edulcorantes podem ser classificados em dois grupos:

Naturais: obtidos a partir de plantas ou eventualmente presentes em alimentos de origem animal. Exemplos: frutose, sorbitol, manitol, esteviosídeo, entre outros;

Sintéticos: obtidos por reações químicas apropriadas de produtos naturais ou não. Exemplos: sacarina, aspartame, ciclamato, acessulfame-K, sucralose, entre outros ${ }^{10}$.

A mistura de um ou mais edulcorantes que confere sabor doce aos alimentos, contendo ou não algum nutriente, é definida como adoçante ${ }^{10}$. Os edulcorantes podem ser organizados, segundo Candebat e Roché ${ }^{11}$, como nutritivos e nãonutritivos de acordo com a quantidade de calorias liberadas durante a metabolização: 
- Nutritivos: são aqueles que, além de adoçar o alimento, fornecem calorias ao organismo, e por isso denominados calóricos.

- Não-nutritivos: são aqueles que, além do sabor doce, não fornecem calorias ao organismo, também chamados de não-calóricos.

Desde a segunda metade do século $\mathrm{XX}$, os edulcorantes vêm apresentando aumento significativo no consumo devido à maior preocupação da população com a saúde e a estética ${ }^{3}$.

Os edulcorantes mais utilizados são ${ }^{12}$ :

- Acessulfame: o acessulfame ou 6-metil-1,2,3-oxatiazina-4(3H)-ona-2,2-dióxido foi descoberto em 1967 por pesquisadores alemães da Hoechst de Frankfurt. Também foi descoberto, que as variações do posicionamento dos substituintes no anel causavam forte influência em sua doçura, concluindo-se que o sal de potássio era o mais adequado para aplicações em alimentos. É o edulcorante sintético de maior resistência ao armazenamento prolongado e a diferentes temperaturas ${ }^{13}$. Adoça de 180-200 vezes mais que a sacarose, seu sabor é percebido de imediato e, em grandes doses, deixa um sabor residual amargo ${ }^{14}$. Sua fórmula estrutural é:

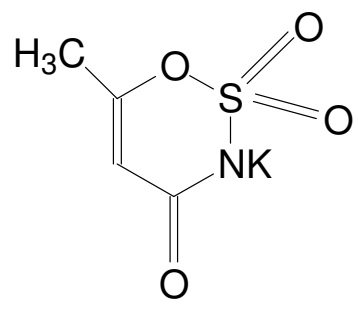

Em 1984, estudos mostraram que o sal de potássio do edulcorante acessulfame, não é metabolizado e nem tem valor calórico significativo. Investigações fármaco-cinéticas em diversos animais e também em humanos mostraram rápida e completa excreção do acessulfame- $\mathrm{K}^{15}$. 
- Aspartame: o aspartame ou éster metílico do N-L- $\alpha$ - $\beta$-aspartil-L-fenilalanina (APM), foi descoberto acidentalmente nos Estados Unidos em 1965 por J. M. Schlatter ${ }^{13}$, quando este tentava desenvolver um sedativo para úlceras. É um dipeptídeo branco, cristalino, inodoro, de baixa caloria e tem poder adoçante 180200 vezes maior que a da sacarose. A fórmula estrutural do aspartame ${ }^{10}$, é apresentada abaixo:

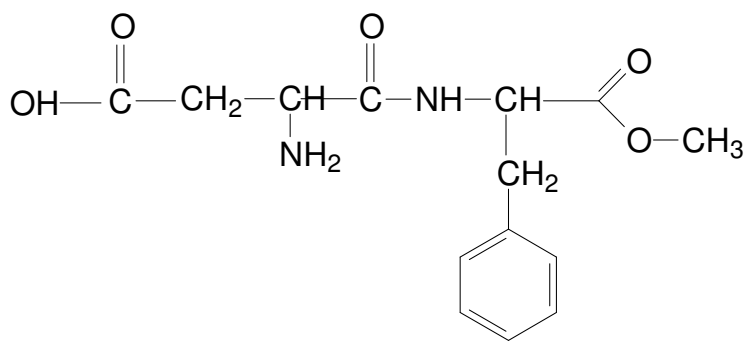

O aspartame é relativamente estável até $150^{\circ} \mathrm{C}$, mas sob certas condições, tais como, temperatura, umidade e $\mathrm{pH}$, este edulcorante pode ser hidrolisado formando aspartilfenilalanina ou dicetopiperazina com a eliminação de metanol ${ }^{10,13}$. Dependendo destas condições a aspartilfenilalanina também pode ser formada a partir da hidrólise da dicetopiperazina. Posteriormente, a aspartilfenilalanina poderá ser hidrolisada formando ácido aspártico e fenilalanina. Estes produtos de reação não apresentam sabor doce ${ }^{10}$. Abaixo de $\mathrm{pH} 3,0$, o aspartame hidrolisa produzindo aspartilfenilalanina e acima de $\mathrm{pH}$ 6,0, apresenta-se na forma de dicetopiperazina. $\mathrm{O}$ Esquema 1 apresenta as principais reações que resultam nestes produtos ${ }^{13}$. 


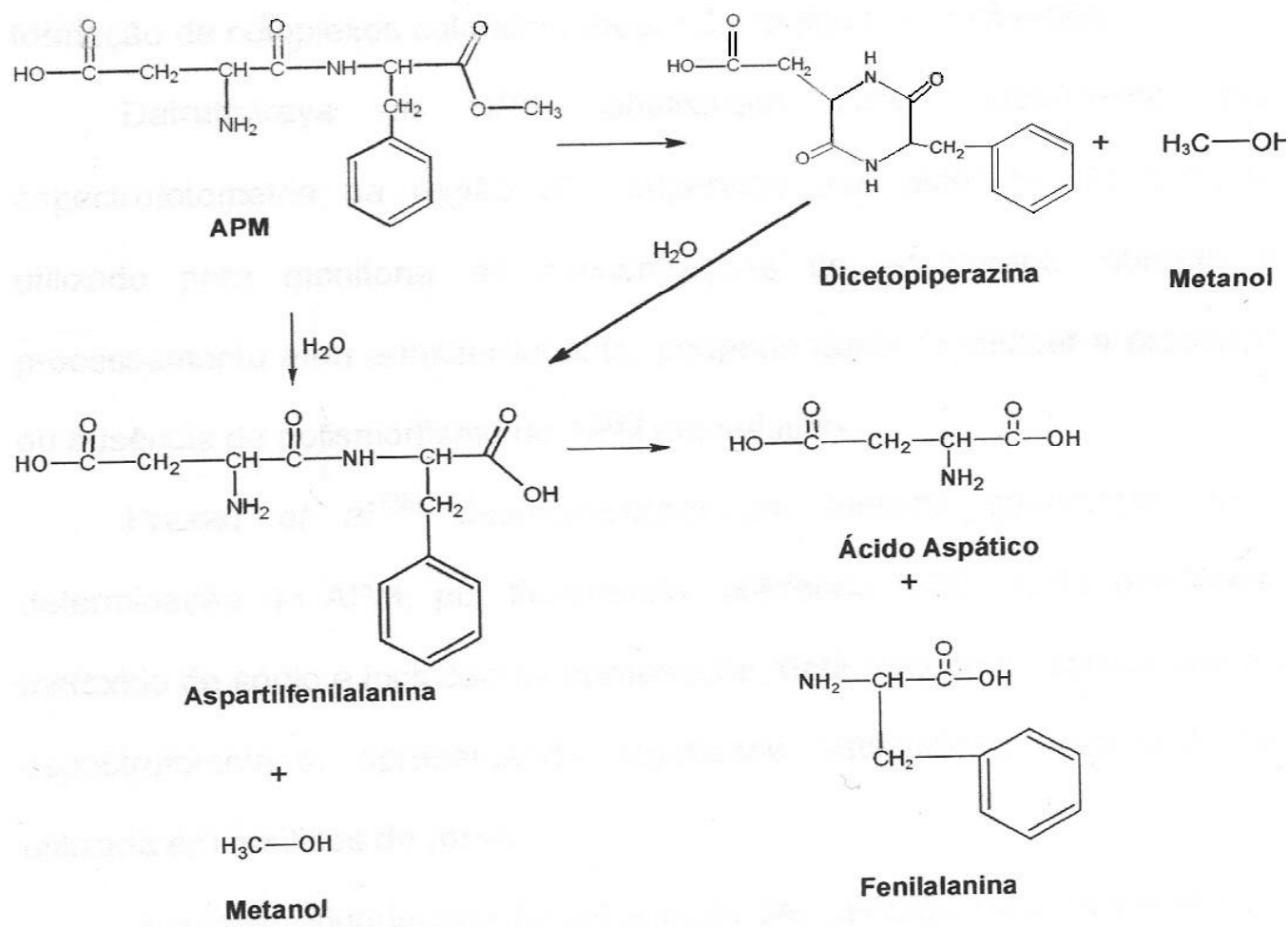

Esquema1: Reações de conversão do aspartame ${ }^{10}$

O metabolismo do aspartame é motivo de discussão e foi bastante estudado em seres humanos, macacos, ratos e coelhos ${ }^{13}$.

O risco de sua ingestão estaria na toxicidade dos produtos de seu metabolismo: fenilalanina, metanol e ácido aspártico. Como um de seus metabólitos é a fenilalanina, seu uso não é recomendado para pessoas portadoras de fenilcetonúria, indivíduos com carência de fenilalanina hidroxilase, enzima responsável pela transformação deste aminoácido em tirosina. Assim, doses elevadas de fenilalanina no organismo podem levar a mudanças de comportamento como depressão, insônia, cefaléia, alterações da visão, etc ${ }^{13}$. 
- Ciclamato: o ciclamato ou ácido ciclohexenossulfâmico foi descoberto em 1939 por Sveda, quando este pesquisador investigava a síntese de sulfamatos em seu trabalho de doutoramento ${ }^{16}$. Inicialmente foi sintetizado sob a forma ácida e de sais de amônio, prata, bário, sódio e cálcio. O seu poder adoçante foi descoberto acidentalmente, e apenas em 1949 entrou no mercado. Como a sacarina, é um edulcorante artificial largamente utilizado no setor alimentício, sendo aplicado em adoçantes de mesa, bebidas dietéticas, geléias, sorvetes, gelatinas, etc ${ }^{13,16}$. A fórmula estrutural do ciclamato de sódio é:

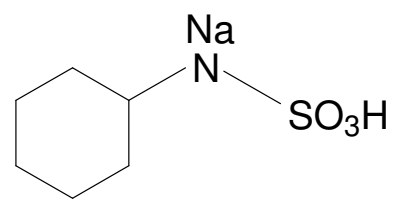

No final da década de 60 , iniciaram-se alguns estudos ${ }^{13}$, sobre 0 metabolismo e a toxicidade do ciclamato em seres humanos e em alguns animais. Desde então, diversas investigações foram realizadas a fim de se comprovar a carcinogenicidade deste edulcorante ${ }^{16}$. O mecanismo metabólico do ciclamato é mostrado no Esquema 2. O organismo humano tem demonstrado tendência diferenciada ao metaboliza-lo. Aproximadamente de 8 a $10 \%$ da população consumidora deste edulcorante, pode converter $1 \%$ do ciclamato em ciclohexilamina, potencialmente carcinogênica, uma vez que esta conversão depende da flora intestinal existente e das características fisiológicas de cada indivíduo. 


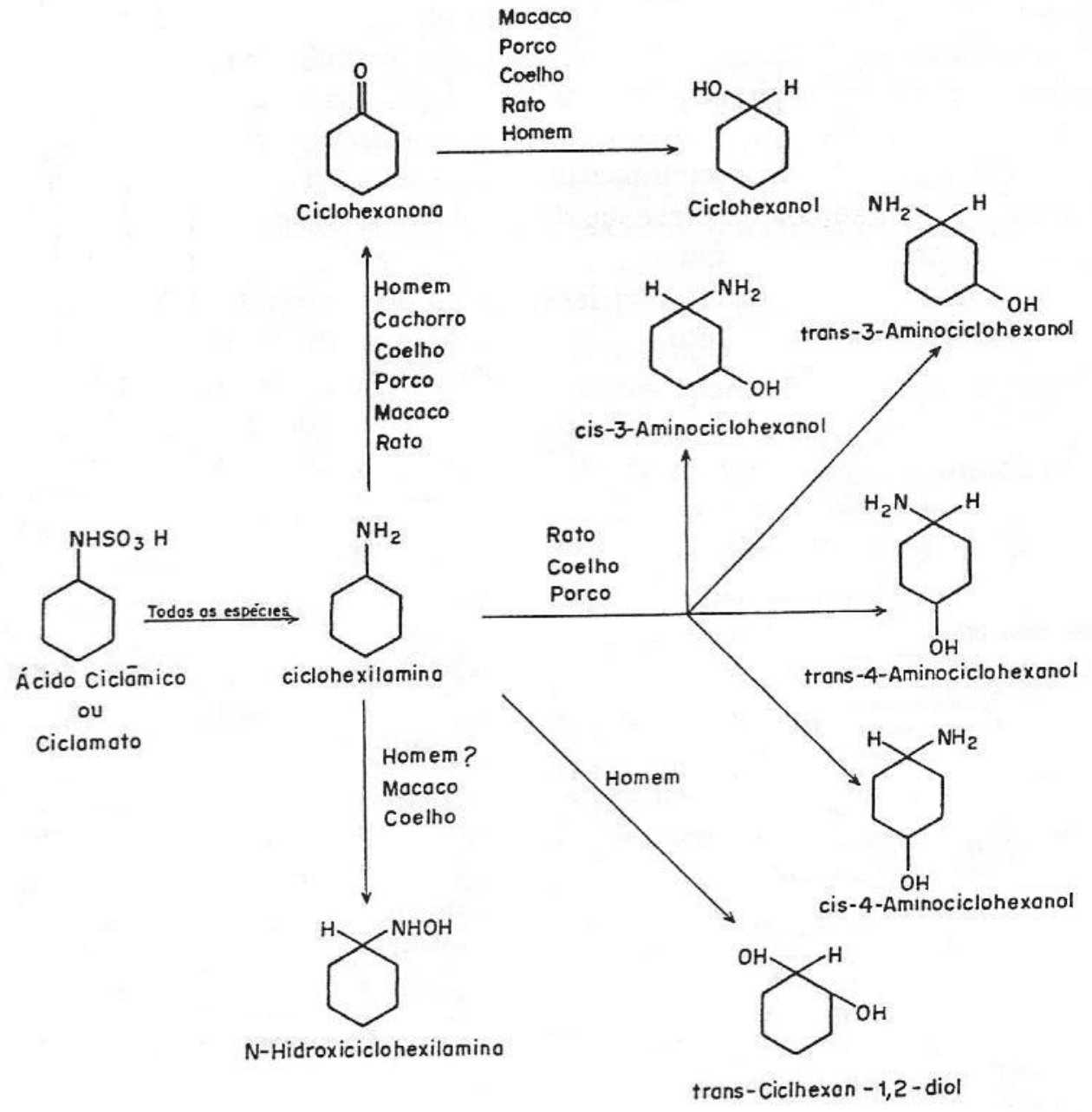

Esquema 2: Metabolismo do ciclamato em mamíferos ${ }^{13}$

O metabolismo do ciclohexilamina também é objeto de estudos e diversas rotas metabólicas desta substância foram identificadas, gerando controvérsias quanto ao potencial carcinogênico desta substância ${ }^{13}$.

- Esteviosídeo: $\quad$ o 19-O- $\beta$-glucopiranosil-13-O $\beta$-glucopiranosil $\quad(1,2)-\beta$ glucopiranosil]-steviol foi descoberto por cientistas em 1905. Este edulcorante natural permaneceu esquecido por muitos anos, passando a ser bastante empregado no fim do século $X X$, devido às desconfianças de potencial 
carcinogênico de edulcorantes artificiais. Desde então, seu uso foi bastante difundido principalmente no Japão, sendo empregado como edulcorante em alimentos e bebidas desde esta década ${ }^{17}$. Antes de ser descoberto pela ciência, há muitos anos era utilizado pelos índios guaranis para adoçar o mate e algumas bebidas medicamentosas. É extraído das folhas de Stevia rebaudiana ${ }^{18}$, originária da fronteira do Brasil com o Paraguai. Das suas folhas, se extrai o esteviosídeo, edulcorante natural de sabor doce com poder adoçante 300 vezes maior do que a sacarose. Não produz cáries, nem é calórico, tóxico e fermentável ${ }^{17,19}$. A fórmula estrutural da molécula de esteviosídeo é apresentada a seguir:

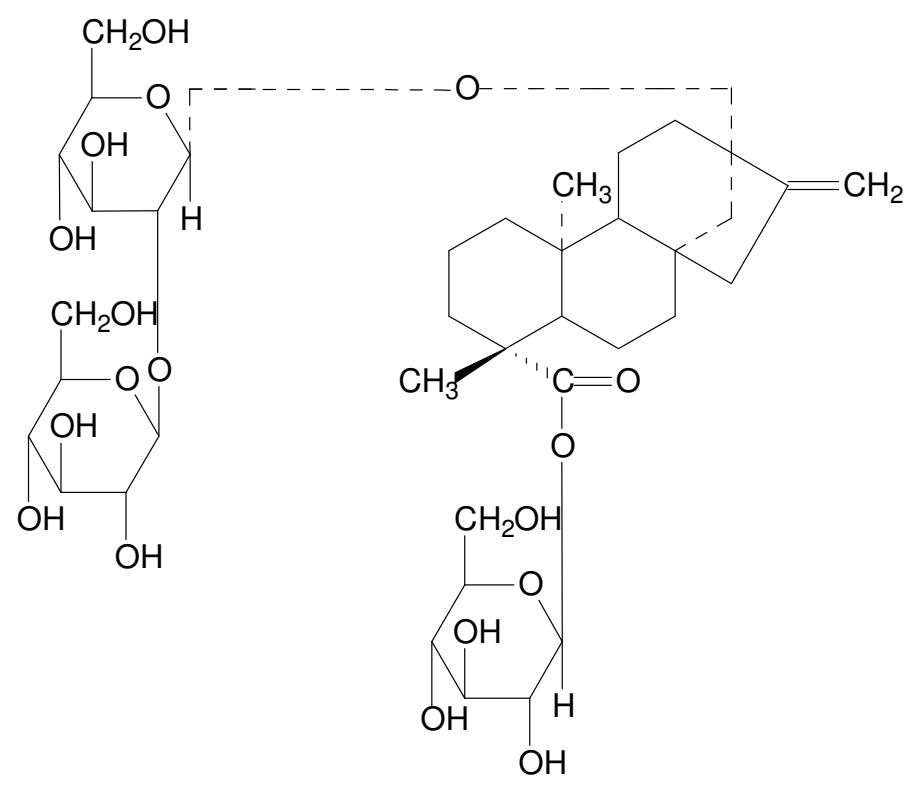

Segundo Geuns ${ }^{17}$ existem várias controvérsias sobre o metabolismo do esteviosídeo. Alguns artigos relatam a produção de esteviol, que pode ser potencialmente mutagênico, em bactérias e diversas espécies animais. No entanto, outros experimentos foram realizados in vivo, em que foi concluída a real formação 
do esteviol, mas que não era metabolizado pelo organismo devido às condições anaeróbicas das bactérias do trato intestinal existentes no colón humano.

- Sacarina: a sacarina (o-benzóico sulfimida), é o mais antigo dos edulcorantes artificiais, tendo sido acidentalmente descoberta e sintetizada em 1879 por Fahlberg $^{20}$, quando este investigava 0 mecanismo de oxidação do toluenosulfonamida. O composto no qual pretendia obter, espirrou ocasionalmente em seus dedos. Ao sair do laboratório, não lavando adequadamente suas mãos, percebeu sabor doce ao ingerir uma fatia de pão no café da tarde. Foi então que Fahlberg observou traços do produto de oxidação (sacarina) em seus dedos, passando a ser empregado, depois de muitos anos, como aditivo alimentar em situações específicas. Durante mais de um século, a sacarina tem sido alternativamente empregada como aditivo alimentar ${ }^{13,20}$.

Tem poder adoçante 400-500 vezes maior do que a sacarose. Em altas concentrações, deixa sabor residual amargo. É de fácil solubilidade e estável em altas temperaturas $^{21}$. Em 1986 foi declarada segura para a saúde, se usada em concentrações adequadas, após diversos trabalhos técnico-científicos ${ }^{21}$. Havia forte suspeita sobre seu potencial carcinogênico, mas destas provinham de testes com cobaias que ingeriram doses maciças desta substância ${ }^{20}$. A fórmula estrutural da sacarina sódica é:

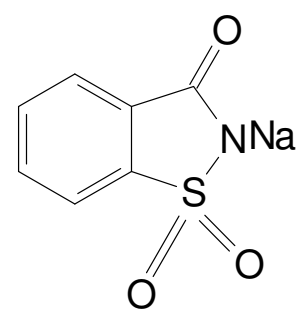


Como o ciclamato de sódio, a sacarina sódica também apresenta várias controvérsias sobre o metabolismo e sua toxicidade. Alguns artigos relatam o aparecimento de diversos tumores em ratos $^{20}$.

Em contraposição, outros estudos dizem que não há metabolização em pequenas doses para apresentação de potencial carcinogênico. Segundo estes autores, altas doses deste edulcorante (mais ou menos $5 \%$ da dose diária alimentar de um camundongo), durante vários meses, podem levar ao desenvolvimento de tumores $^{20}$.

\subsubsection{O que dá o sabor doce aos edulcorantes?}

Os edulcorantes podem pertencer a diversas classes químicas. Devido a esta diversidade estrutural, muitos estudos têm sido realizados com o objetivo de conhecer a relação existente entre suas propriedades físico-químicas e o sabor doce apresentado por essas substâncias.

Dentre as diversas teorias relatadas na literatura, aquela desenvolvida por Shallemberger e completada por Kier tem ampla repercussão. Esta hipótese fundamenta-se na propriedade biológica estruturalmente específica do edulcorante (Figura 1). Nos edulcorantes, existem grupos funcionais constituídos por átomos eletronegativos (A e B) distanciados entre si, de 2,5 a $4 \AA$. O átomo $A$ está ligado covalentemente a um próton $\left(\mathrm{H}^{+}\right)$. A manifestação do sabor doce depende principalmente do "encaixe" destes grupos funcionais $(\mathrm{AH}-\mathrm{B})$ ao sítio receptor dos papilos da língua (receptor, A'H-B'). Este "encaixe" corresponde à formação de duas pontes de hidrogênio (Figura 1d). Kier propôs, além destas duas, a formação de uma terceira ligação estando relacionada com a região hidrofóbica do edulcorante com o 
sítio receptor. Esta hipótese poderia explicar o alto poder adoçante de certas substâncias. Roberto-Neto e Ornellas fizeram uma análise teórica do modelo proposto por Shallemberger escolhendo para estudo a classe das 2-alquil-5nitroanilinas. Este estudo mostrou que o modelo apresentado por Shallemberger não poderia ser aplicado para esta classe funcional. Para essas substâncias o sabor doce pode estar relacionado com propriedades macroscópicas não específicas ${ }^{13}$.<smiles>O=c1[nH]c(=O)c2ccccc2o1</smiles>

(a)

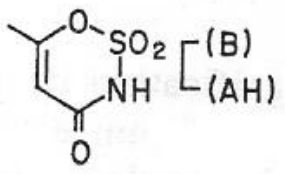

(b)<smiles>O=S(=O)(O)NC1CCCCC1</smiles>

(c)

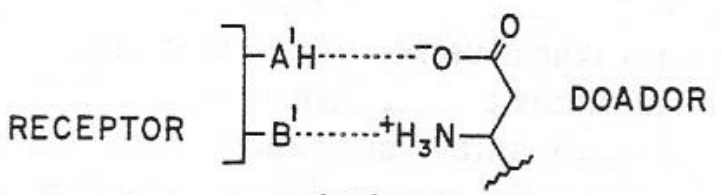

(d)

Figura 1. Representação dos grupos funcionais $(A H-B)$ de cada edulcorante (a) sacarina, (b) acessulfame, (c) ciclamato e (d) representação esquemática da interação entre o sítio receptor $\left(A^{\prime} H\right.$ $\left.\mathrm{B}^{\prime}\right)$ e o sítio doador $(\mathrm{AH}-\mathrm{B})$ do aspartame ${ }^{13^{3}}$.

No entanto, esta teoria explica apenas o "sabor doce" dos edulcorantes artificiais, e não dos naturais como o esteviosídeo, por exemplo, investigado neste trabalho.

Uma outra teoria para a sensação do sabor dos diferentes edulcorantes é citada por Bear et $a^{22}$. Segundo Bear, na presença de sacarose algumas proteínas e outras substâncias são ativadas nas papilas gustativas, receptores acoplados às proteínas G. Estes receptores funcionam como amplificadores dos sinais transmitidos pelas células. Assim como a sacarose, outros edulcorantes também 
ativam os mesmos receptores acoplados às proteínas G proporcionando o sabor doce $^{23}$

A papila gustativa é um receptor sensorial do paladar, que é constituído por células epiteliais, localizadas em torno de um poro central na membrana mucosa basal da língua ${ }^{23}$. Na superfície da língua, existem dezenas de papilas gustativas, cujas células sensoriais percebem os quatro sabores primários, aos quais chamamos sensações gustativas primárias: amargo, azedo ou ácido, salgado e doce. A disposição dos receptores dos sabores primários na língua humana, é representada na Figura 2. De sua combinação resultam centenas de sabores distintos. A distribuição dos quatro tipos de receptores gustativos, na superfície da língua, não é homogênea ${ }^{24}$.

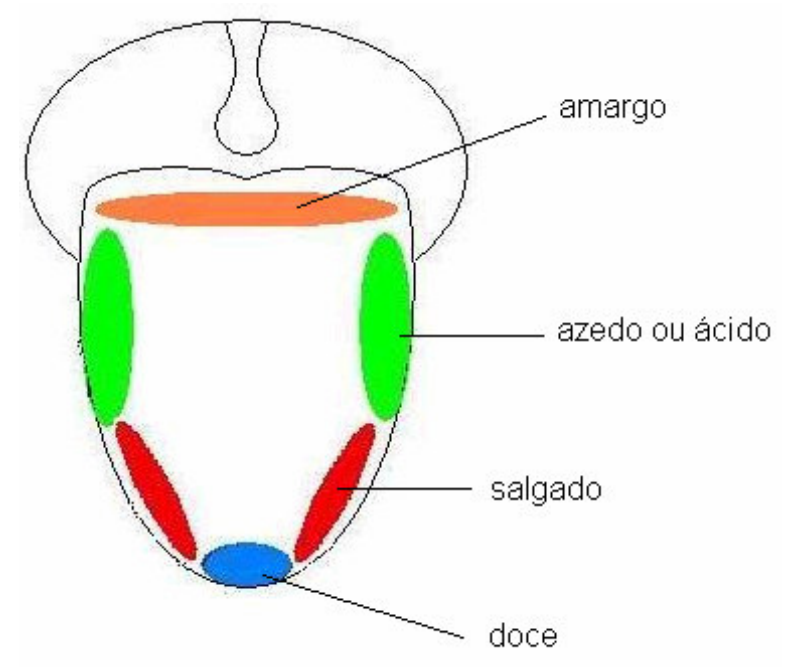

Figura 2. Ilustração das diferentes regiões da língua, receptores de sabor ${ }^{22}$.

Até os últimos anos acreditava-se que existiam quatro tipos inteiramente diferentes de papilas gustativas, cada qual detectando uma das sensações gustativas primárias, em particular. Sabe-se agora que todas as papilas gustativas 
possuem alguns graus de sensibilidade para cada uma das sensações gustativas primárias. Entretanto, cada papila normalmente tem maior grau de sensibilidade para uma ou duas das sensações gustativas. O cérebro detecta o tipo de gosto pela relação (razão) de estimulação entre as diferentes papilas gustativas ${ }^{23}$.

Na realidade, segundo Marzzocco e Torres $^{25}$ a detecção do sabor doce é feita por uma grande variedade de receptores ligados a uma vasta família de proteínas chamadas proteínas $G$.

As proteínas G são assim designadas pela propriedade de ligar-se a nucleotídeos de guanina $^{25}$. São compostas por três subunidades, $\alpha, \beta$ e $\gamma$, sendo a subunidade $\alpha$, aquela que apresenta a capacidade de associação aos nucleotídeos ${ }^{26}$.

Além do seu papel importante no sentido do sabor, os receptores acoplados às proteínas G têm ainda um papel importante no olfato e, segundo pesquisas recentes, podem ser responsáveis por doenças endócrinas e estas, por sua vez, podem estar ligadas à obesidade ${ }^{26}$.

Quando os sensores específicos deste sabor são ativados, um sinal é emitido para o cérebro, que o interpreta como doce ${ }^{23}$.

\subsection{Considerações sobre as técnicas a serem utilizadas}

\subsubsection{Análise Térmica}

Segundo Mackenzie ${ }^{27}$, a análise térmica foi definida como sendo "um grupo de técnicas nas quais uma propriedade física de uma substância e/ou seus produtos de reação é medida, enquanto a amostra é submetida a uma programação 
controlada de temperatura". A análise térmica compreende, atualmente, várias técnicas, entre as quais estão a termogravimetria (TG), a análise térmica diferencial (DTA) e a calorimetria exploratória diferencial (DSC) que serão as técnicas de análise térmica utilizadas na realização deste trabalho.

\subsubsection{Termogravimetria (TG)}

A termogravimetria baseia-se no estudo da variação de massa de uma determinada amostra, resultante de uma transformação física (sublimação, evaporação, condensação) ou química (degradação, decomposição, oxidação) em função do tempo ou da temperatura ${ }^{28}$. Embora a técnica dependa estritamente de

inúmeros fatores experimentais ${ }^{28-30}$, é uma técnica que, quando associada a outras técnicas instrumentais, adquire aplicabilidade quase ilimitada, possibilitando investigar a estrutura das mais variadas substâncias e materiais ${ }^{30}$. A partir das curvas termoanalíticas, parâmetros cinéticos como energia de ativação $(E)$, fator préexponencial de Arrhenius (A) e tempo de vida de substâncias também podem ser obtidos $^{31,36}$.

\subsubsection{Análise Térmica Diferencial (DTA)}

Na Análise Térmica Diferencial o que se acompanha é a variação na propriedade física temperatura da amostra, em relação a um material que não apresenta absorção ou liberação de calor, ou seja, a referência, enquanto são submetidas a uma programação controlada de temperatura ${ }^{21,36}$. 


\subsubsection{Calorimetria Exploratória Diferencial (DSC)}

A Calorimetria Exploratória Diferencial é uma técnica na qual é acompanhada a variação de energia de uma substância em relação a uma referência. Em um experimento de DSC, mede-se a variação de entalpia que ocorre entre a amostra e a referência durante o processo de aquecimento/resfriamento. Assim como na termogravimetria, os resultados de DSC podem ser influenciados por alguns parâmetros experimentais. Desta forma, é importante fixar condições experimentais para a repetibilidade de resultados de experimentos que envolvem $\operatorname{DSC}^{21,36}$.

\subsubsection{Análise Elementar (AE)}

No presente momento, vários fabricantes produzem instrumentos automáticos para a análise de um ou mais elementos comumente encontrados em compostos orgânicos, incluindo carbono, hidrogênio, oxigênio, enxofre e nitrogênio. Todos esses instrumentos estão baseados na oxidação em alta temperatura dos compostos orgânicos, que converte os elementos de interesse em moléculas gasosas. Na maioria dos instrumentos, a detecção da condutividade térmica serve para completar as determinações. Geralmente estão equipados com dispositivos que automaticamente carregam amostras de massa determinada para a área de combustão ${ }^{32}$. 


\subsubsection{Espectroscopia na Região do Infravermelho (IR)}

A espectroscopia na região do infravermelho baseia-se na absorção de radiação infravermelha por moléculas de uma determinada substância. Esta técnica é útil para investigar a presença de grupos funcionais em um dado material. Cada grupo absorve em freqüência característica de radiação na região do infravermelho. Assim, um gráfico de intensidade de radiação versus freqüência, o espectro de infravermelho, permite caracterizar os grupos funcionais de um padrão ou de um material desconhecido ${ }^{33}$.

\subsubsection{Análise por Difração de raios X (XRD)}

O princípio fundamental dos raios $\mathrm{X}$ se baseia na radiação eletromagnética de comprimento de onda curto produzida pela aceleração ou desaceleração de elétrons de alta energia ou pelas transições de elétrons dos orbitais internos dos átomos. $\mathrm{O}$ intervalo de comprimento de onda dos raios $X$ vai de cerca de $10^{-5} \AA$ até $100 \AA$. A espectroscopia de raios $X$ convencional utiliza raios $X$ na região de $0,1 \AA$ até $25 \AA^{32}$.

Da mesma forma que para as outras radiações eletromagnéticas, a interação entre o vetor campo elétrico da radiação $X$ e os elétrons da matéria que a radiação atravessa resulta no espalhamento. Quando os raios X são espalhados pelo ambiente ordenado de um cristal, ocorre a interferência entre os raios espalhados (tanto destrutiva como construtiva) porque as distâncias entre os centros espalhadores são da mesma ordem da grandeza que o comprimento de onda da radiação. $\mathrm{O}$ resultado é a difração ${ }^{33}$. 


\subsubsection{Cinética de decomposição térmica}

Cinética química é o estudo da dependência da extensão ou velocidade de uma reação química com o tempo ou temperatura. Os estudos cinéticos utilizam-se de modelos matemáticos que quantificam a relação existente entre a velocidade de reação, tempo e temperatura ${ }^{34}$.

Métodos cinéticos baseados em termogravimetria vêm sendo amplamente relatados na literatura com o intuito de elucidar mecanismos de reação no estado sólido, tais como: decomposição térmica e desidratação de materiais ${ }^{35}$. Dois métodos podem ser utilizados para avaliar a cinética de decomposição por TG; o método isotérmico e o não-isotérmico ou dinâmico.

$\mathrm{Na}$ cinética isotérmica das curvas TG são obtidas numa determinada temperatura, registrando-se a variação da massa da amostra em função do tempo. Já na cinética não-isotérmica a amostra é aquecida linearmente, com razão fixa de aquecimento, $\beta$, registrando-se a curva de variação da massa em função da temperatura ou do tempo ${ }^{31}$.

O conceito da cinética de estado sólido surgiu a partir de experimentos isotérmicos, bem antes dos primeiros instrumentos de medida dinâmica tornarem-se comercialmente disponíveis.

Ambos os métodos apresentam algumas vantagens e desvantagens. O maior problema do experimento isotérmico é que a amostra requer algum tempo para alcançar a temperatura programada, fato que se não for controlado conduz a perda de informações. Além disso, no método isotérmico algumas vezes torna-se difícil observar a etapa inicial de reação devido à variação brusca de temperatura causada sobre a atmosfera do forno. 
O método dinâmico resolve este problema e é mais prático e rápido, por isso tornou-se mais utilizado no campo da cinética do estado sólido. Porém, a heterogeneidade do sistema, durante o curso do processo térmico e a utilização de tratamentos matemáticos mais complexos dificulta a análise dos dados experimentais 36-37.

Neste trabalho, será utilizado o método de Flynn, Wall e Ozawa ${ }^{38-39}$ que é preferido por requerer menos tempo experimental, sendo necessárias pelo menos três curvas, obtidas em razões de aquecimento distintas. Este método permite a determinação da energia de ativação $\left(E_{a}\right)$ e do fator pré-exponencial $(\log A)$ usando a integral das curvas TG dinâmicas a várias razões de aquecimento.

Para a determinação dos parâmetros cinéticos $E_{a}$ e $\log A$ será utilizado um programa computacional da TA Instruments desenvolvido para esta finalidade, sendo necessária a obtenção de curvas TG em pelo menos três razões de aquecimento linear, $\beta$, sob atmosfera inerte ${ }^{38}$.

O programa, para uma reação de decomposição, leva em consideração a equação básica que relaciona a velocidade de conversão d $\alpha / d T$ à uma razão de aquecimento linear, $\beta$, com a energia de ativação, $\mathrm{E}$, fator pré-exponencial de Arrhenius e a função do modelo cinético $f(\alpha)$, a qual está expressa pela equação $1^{35}$.

$$
\frac{d \alpha}{d T}=\frac{A}{\beta} \exp \left(-\frac{E}{R T}\right) f(\alpha)
$$

A energia de ativação encontrada pode ser usada para calcular o tempo de vida dos edulcorantes em cada temperatura ${ }^{35}$. 
A descrição detalhada do método, suas equações matemáticas e fundamentação, já foram objeto de extensivas considerações em trabalhos prévios ${ }^{35}$, 38, 39 e não faria sentido discuti-los, novamente.

O grupo dos Profs. Drs Clóvis A. Ribeiro e Marisa S. Crespi da Unesp Araraquara também vem se dedicando ao desenvolvimento de métodos cinéticos no Brasil. Seus trabalhos são de grande valia para os interessados, como por exemplo a tese de Guinese ${ }^{35}$.

\subsection{Revisão Bibliográfica}

Com a realização da revisão bibliográfica, pode-se comprovar que existem poucos trabalhos relacionados com a análise térmica desses edulcorantes. A seguir, são descritos alguns deles:

Em 2005, Icbudak et al. ${ }^{43}$ estudaram a decomposição térmica do complexo metálico acessulfamato de diaquabis $\left(N, N^{\prime}\right.$-dimetil-1,2-etanodiamina) níquel(II). Nesse estudo, a decomposição térmica deste complexo foi realizada por TG, DTG e DTA, acoplado a um espectrômetro de massas. Os resultados obtidos mostram quais são os produtos de decomposição, bem como uma relação entre os processos térmicos e de ionização estabelecidos prevendo com maior precisão o caminho da decomposição. O estudo do comportamento térmico do complexo metálico foi importante para a determinação das propriedades e diferenças estruturais dos complexos.

Conceição ${ }^{40}$ em 2004, estudou a degradação térmica de adoçantes contendo aspartame, utilizando TG e DSC até $900^{\circ} \mathrm{C}$, bem como as melhores condições analíticas para a obtenção de curvas TG de formulações de adoçantes e do 
edulcorante. Os perfis termogravimétricos e calorimétricos revelaram a conversão do aspartame em 5-benzil, sendo confirmada por IR e XRD. Outros produtos de decomposição foram confirmados por HPLC ${ }^{41}$. Neste trabalho, também foi realizado um estudo cinético de decomposição do aspartame, avaliando-se o modelo cinético que melhor se ajustou aos dados experimentais ${ }^{40}$.

Mais tarde, Simêncio ${ }^{10}$ desenvolveu um método para quantificação simultânea de componentes de misturas ternárias utilizando resultados de TG, submetidos a tratamentos quimiométricos. Como sistemas modelo foram usadas, inicialmente, formulações farmacêuticas, não efervescentes contendo ácido Lascórbico $(\mathrm{AA})$, celulose microcristalina $(\mathrm{CM})$ e água. Após o estudo realizado com as formulações de AA, a mesma metodologia de quantificação foi aplicada para adoçantes artificiais comerciais contendo aspartame (APM), lactose $\alpha$ monohidratada (LM) e dióxido de silício. Os modelos quimiométricos propostos utilizados no tratamento das curvas TG foram capazes de prever satisfatoriamente os componentes presentes em formulações de AA, mas não foram suficientes para prever o APM presente nas formulações comerciais.

O estudo dos espectros vibracionais na região do infra-vermelho (IR) de dois novos sacarinatos de césio $\left[\mathrm{Cs}\left(\mathrm{C}_{7} \mathrm{H}_{4} \mathrm{NO}_{3} \mathrm{~S}\right)\left(\mathrm{C}_{7} \mathrm{H}_{5} \mathrm{NO}_{3} \mathrm{~S}\right) . \mathrm{H}_{2} \mathrm{O} \quad\right.$ (1) e $\mathrm{Cs}\left(\mathrm{C}_{7} \mathrm{H}_{4} \mathrm{NO}_{3} \mathrm{~S}\right) \cdot 0,5 \mathrm{H}_{2} \mathrm{O}$ ] (2) foi realizado por Naumov \& Jovanovski ${ }^{44}$ em 2000. Analisaram-se os espectros de IR dos sacarinatos protonados e parcialmente deuterados. Os valores de freqüência dos estiramentos $\mathrm{CO}$ e $\mathrm{SO}_{2}$ ao longo da absorção na presença do estiramento $\mathrm{NH}$, no espectro de (1) representam evidências de que este composto seria um sacarinato. A temperatura de decomposição do sacarinato (486 $\mathrm{C}$, pico exotérmico) é $150^{\circ} \mathrm{C}$ maior que a da 
sacarina (337ํㅡ $\mathrm{C}$, pico endotérmico). Os resultados obtidos a partir da análise térmica e do IR foram utilizados para elucidação das estruturas dos compostos.

Naumov et a/ ${ }^{45}$ em 2000, estudaram a síntese dos sacarinatos de potássio (KSac), sódio (NaSac), rubídio (RbSac), césio (CsSac) e amônio (AmmSac) bem como a decomposição térmica destes compostos no intervalo de temperatura $20-600{ }^{\circ} \mathrm{C}$, sendo realizados estudos de TG, DTG e DTA em atmosfera de hélio, e DSC em atmosfera de nitrogênio. Os resultados da análise térmica e da espectroscopia de infravermelho do NaSac e do AmmSac foram correlacionados com os dados estruturais correspondentes, uma vez que os dados para KSac, RbSac e CsSac foram utilizados para fazer inferência sobre estruturas cristalinas. Com exceção do AmmSac, todos os compostos foram anteriormente desidratados para estudos de decomposição e de espécies de sacarinatos deprotonados.

Em 1999, Kroyer $^{42}$ estudou a estabilidade do esteviosídeo em diferentes processos e condições de estocagem, bem como os efeitos da interação com soluções aquosas contendo vitaminas: ácido cítrico, ácido ascórbico, ácido fosfórico, riboflavina, ácido tartárico com este mesmo edulcorante. A análise da estabilidade do composto foi realizada por HPLC (cromatografia líquida de alta eficiência) em temperaturas de $40-200^{\circ}$ C. Segundo o autor, o composto se mostrou estável até 120 C. Após essa temperatura, iniciou-se a degradação da amostra, que se completa a $200^{\circ}$ C. O esteviolbiosídeo e glucose foram identificados como produtos da degradação desse edulcorante.

O grupo LATEQS realizou estudos termogravimétricos e calorimétricos dos edulcorantes sacarina ${ }^{21}$ e aspartame ${ }^{10}$. No entanto, ainda não havia sido investigado por TG e DSC o comportamento térmico do acessulfame $K$, ciclamato de sódio e esteviosídeo. Embora o comportamento térmico da sacarina sódica já tenha sido 
investigado por Naumov et al ${ }^{45}$ e da sacarina por Bernal et al ${ }^{21}$ ainda não haviam sido avaliados os parâmetros cinéticos da decomposição térmica destes edulcorantes.

Vários trabalhos sobre cinética no estado sólido utilizando técnicas calorimétricas ou termogravimétricas são relatados na literatura ${ }^{34-35}$. No entanto, são raros os estudos sobre cinética de edulcorantes ${ }^{41}$. 


\section{OBJETIVOS}

Os objetivos gerais do trabalho foram:

$\checkmark$ Caracterizar as etapas de decomposição térmica dos compostos e seus intermediários, utilizando-se técnicas termoanalíticas (TG/DTG), IR e difração de raios $\mathrm{X}$;

$\checkmark$ Observar, a partir das curvas DSC, mudanças físico-químicas decorrentes da liberação ou absorção de calor; durante os eventos térmicos;

$\checkmark$ Determinar por TG, os parâmetros cinéticos, tais como energia de ativação e fator pré-exponencial de Arrhenius, da reação de decomposição térmica de cada edulcorante.

A realização deste trabalho pretende contribuir na compreensão do comportamento térmico dos edulcorantes acessulfame-K, aspartame, ciclamato de sódio, esteviosídeo, sacarina e sacarina sódica. Os resultados obtidos poderão servir como parâmetro para a escolha de edulcorantes em determinadas aplicações como o uso de adoçantes de mesa na indústria alimentícia ou em cozinhas domésticas, nas quais podem vir a serem aquecidos. Como também podem auxiliar na determinação de intermediários tóxicos desses edulcorantes que podem se formar durante o aquecimento do alimento. 


\section{PROCEDIMENTO EXPERIMENTAL}

\subsection{Reagentes e soluções}

Para a realização deste trabalho, foram utilizados como reagentes os edulcorantes acessulfame- $\mathrm{K}\left(\mathrm{C}_{4} \mathrm{H}_{4} \mathrm{KNO}_{4} \mathrm{~S}-\right.$ Fluka PA), aspartame $\left(\mathrm{C}_{14} \mathrm{H}_{18} \mathrm{~N}_{2} \mathrm{O}_{5}-\right.$ Natural Pharma), ciclamato de sódio $\left(\mathrm{C}_{6} \mathrm{H}_{12} \mathrm{NNaO}_{3} \mathrm{~S}\right.$ - Natural Pharma), esteviosídeo $\left(\mathrm{C}_{38} \mathrm{H}_{60} \mathrm{O}_{18}\right.$ - Steviafarma Industrial $\left.\mathrm{S} / \mathrm{A}\right)$ e sacarina sódica $\left(\mathrm{C}_{7} \mathrm{H}_{4} \mathrm{NNaO}_{3} \mathrm{~S} .2 \mathrm{H}_{2} \mathrm{O}\right.$ Natural Pharma).

$\mathrm{Na}$ recristalização dos edulcorantes ciclamato de sódio e sacarina sódica foram utilizados os solventes acetona $\left[\left(\mathrm{CH}_{3}\right)_{2} \mathrm{CO}-\mathrm{J}\right.$. T. Baker] e álcool etílico $\left(\mathrm{C}_{2} \mathrm{H}_{5} \mathrm{OH}\right.$ - Synth), respectivamente. Para a preparação da sacarina ácida foi utilizado ácido clorídrico $(\mathrm{HCl}-\mathrm{J}$. T. Baker $)$

Também foi utilizado brometo de potássio $(\mathrm{KBr}$ - Spectrum) de grau espectroscópico no preparo das pastilhas para análise por FT-IR.

\subsection{Recristalização dos edulcorantes}

\subsubsection{Recristalização do ciclamato de sódio e sacarina sódica}

Para a recristalização do ciclamato de sódio e sacarina sódica, foram utilizados $3 \mathrm{~g}$ dos edulcorantes e adicionou-se água destilada em quantidade mínima para cada solubilização, que foi completada utilizando-se um conta-gotas. Após solubilizadas, acrescentou-se acetona gelada e álcool etílico, respectivamente, 
aproximadamente 5 a 6 vezes o volume de água usado na dissolução. $O$ frasco contendo a solução foi acondicionado em freezer por 24 h. Após este período ocorreu a formação dos cristais, que foram filtrados e lavados com os solventes gelados respectivos. As substâncias filtradas foram transferidas para placas de Petri. Essas, por sua vez, foram tampadas com papel alumínio e perfuradas, sendo então acondicionadas em uma estufa a vácuo por 24 h a 25ํ․ .

\subsubsection{Preparação da Sacarina Ácida}

Para a preparação da sacarina ácida, foi utilizada sacarina sódica comercial. Em um balão volumétrico adicionou-se $15 \mathrm{~g}$ de sacarina sódica para solubilização em $30 \mathrm{~mL}$ de água destilada. Após a solubilização, adicionou-se $\mathrm{HCl} 1 \mathrm{M}$ gota a gota. Como não houve precipitação, usou-se então $\mathrm{HCl}$ concentrado. Colocou-se o balão de fundo redondo contendo a solução com o precipitado na geladeira por alguns minutos para facilitar a formação dos cristais. Após a formação dos cristais, o precipitado foi filtrado e lavado com água destilada gelada. Colocou-se o filtrado para secar em uma estufa à vácuo a 25ํㅡ por 24 h.

\subsection{Caracterização dos edulcorantes por espectroscopia na região do infravermelho (FT-IR)}

As amostras dos diferentes edulcorantes $(1,00 \mathrm{mg})$ foram misturadas com $100 \mathrm{mg}$ de brometo de potássio $(\mathrm{KBr})$, maceradas, preparadas em forma de pastilhas com auxílio de uma prensa, e então seus espectros de FT-IR foram obtidos entre 4000 a $400 \mathrm{~cm}^{-1}$, em um espectrofotômetro de infravermelho com transformada 
de Fourier, modelo 5SXC, da Nicolet, com resolução de $4 \mathrm{~cm}^{-1}$. Os espectros de absorção na região do infravermelho foram obtidos para a caracterização prévia dos edulcorantes a serem estudados pelas técnicas termoanalíticas.

Esta técnica também foi utilizada para a caracterização dos intermediários e dos resíduos de decomposição dos edulcorantes.

\subsection{Caracterização dos compostos por Análise Elementar (EA)}

Os edulcorantes também foram caracterizados por análise elementar (EA). As análises foram feitas em um aparelho do tipo CHNS-O, modelo EA-1110, da CE Instruments, previamente aos estudos termoanalíticos.

\subsection{Estudos termoanalíticos}

\subsubsection{Termogravimetria (TG), Termogravimetria Derivada (DTG) e Análise Térmica Diferencial (DTA)}

Foi investigado por TG/DTG e DTA, o comportamento térmico dos edulcorantes. Buscou-se determinar a estabilidade térmica, as etapas de decomposição térmica e as variações de temperatura decorrentes de mudanças físicas ou químicas da amostra.

As curvas TG/DTG e DTA foram obtidas em um módulo simultâneo SDT Q600 da TA Instruments, sob atmosfera dinâmica de ar sintético e de nitrogênio. A vazão utilizada para cada gás foi $100 \mathrm{~mL} \mathrm{~min}^{-1}$, razão de aquecimento de $10^{\circ} \mathrm{C} \mathrm{min}^{-1}$ e intervalo máximo de temperatura de $25^{\circ} \mathrm{C}$ a $900^{\circ} \mathrm{C}$, variando de acordo com a 
estabilidade térmica do resíduo. Utilizou-se suporte de amostra de alumina, massa de amostra de aproximadamente $4 \mathrm{mg}$. Essas condições foram utilizadas pois apresentavam melhor definição de eventos.

\subsubsection{Calorimetria Exploratória Diferencial (DSC)}

Os edulcorantes foram analisados por DSC em temperatura sub-ambiente, de -70 até $130^{\circ} \mathrm{C}$, com o objetivo de investigar a ocorrência de mudanças de fase ou congelamento de umidade, que pudessem ocorrer antes das perdas de massa.

As curvas DSC foram obtidas em um Calorímetro Exploratório Diferencial Q10 da TA Instruments, sob atmosfera dinâmica de nitrogênio, a vazão de $100 \mathrm{~mL}$ $\min ^{-1}$, em suporte de amostra de alumínio tampado com furo central, massa de amostra de aproximadamente $3 \mathrm{mg}$, razão de aquecimento de $10 \stackrel{\circ}{\circ} \min ^{-1}$ e intervalo de temperatura de $-70 \stackrel{\circ}{\mathrm{C}}$ a $130 \stackrel{\circ}{\circ}$.

\subsection{Obtenção e caracterização dos intermediários e dos resíduos dos edulcorantes}

Como a termogravimetria é uma técnica essencialmente quantitativa, se faz necessário o uso de técnicas auxiliares para caracterizar os intermediários estáveis e/ou os resíduos de decomposição térmica das amostras.

Devido à pequena quantidade de resíduo obtido na termobalança, os mesmos foram conseguidos de forma preparativa, simulando-se as condições experimentais da TG, em um forno Alumini Top, da EDG, em quantidade suficiente para caracterização por IV. Para isso, cerca de 500 mg de cada amostra de edulcorante, 
foram aquecidas até a temperatura correspondente aos intermediários e aos resíduos na curva TG, sob atmosfera dinâmica de ar.

Os intermediários e os resíduos do edulcorante ciclamato de sódio foram obtidos em cadinhos de níquel de $30 \mathrm{~mL}$. Os intermediários e os resíduos dos edulcorantes aspartame, acessulfame-K, esteviosídeo e sacarina sódica foram obtidos em cadinhos de alumina de $10 \mathrm{~mL}$. A alumina foi usada quando se observou contaminação do material nas difrações de raios $X$

Após a obtenção, os intermediários e os resíduos foram caracterizados por IR, de 4000 a $400 \mathrm{~cm}^{-1}$, em um espectrofotômetro de infravermelho com transformada de Fourier, modelo 5SXC, da Nicolet, com resolução de $4 \mathrm{~cm}^{-1}$, usando pastilhas de $\operatorname{KBr}(1 \%, m / m)$.

Em determinados casos, foi necessário caracterizar os intermediários e resíduos por difração de raios X, obtida em um gerador Rigaku Rotaflex, modelo RU200B, com goniômetro horizontal multipurpose, utilizando-se o método do pó. O banco de dados JADE 5.0 MDI foi usado para identificar os difratogramas.

Além dessas caracterizações, julgou-se necessário também a caracterização dos eventos térmicos da sacarina $\mathrm{H}$ visualmente. Com esse propósito, uma amostra de aproximadamente $1,0 \mathrm{~g}$ de sacarina foi aquecida em um tubo de ensaio $(20 \mathrm{~cm})$, imerso em óleo mineral, com um termômetro acoplado ao tubo.

\subsection{Cinética de decomposição térmica}

Realizou-se o estudo da cinética de decomposição térmica dos edulcorantes aspartame e sacarina $\mathrm{H}$ utilizando-se o método de Flynn-Wall e Ozawa baseado em curvas termogravimétricas (TG). 
As curvas foram obtidas em razões de aquecimento $(\beta)$ de 2,5; 5,0; 7,5 e 10 ${ }^{\circ} \mathrm{C} \min ^{-1}$, de 25 a $450 \stackrel{\circ}{\circ}$. A massa de amostra utilizada foi de aproximadamente 4,0 mg, em suporte de alumina, atmosfera dinâmica de $\mathrm{N}_{2}$ com vazão de $100 \mathrm{~mL}$ min-1 e níveis de conversão $(\alpha)$ de 5,0; 10,0;15,0;20,0;25,0;30,0; 35,0; 40,0; 45,0 e 50,0 $\%$.

Para a determinação dos parâmetros cinéticos utilizou-se o software TGAKinV4.0 (TA Instruments) $)^{39,46-48 .}$

Para os demais edulcorantes (acessulfame-K, esteviosídeo e sacarina sódica) não foi possível à realização do estudo cinético devido à sobreposição dos eventos térmicos. 


\section{RESULTADOS E DISCUSSÃO}

\subsection{Recristalização do ciclamato de sódio e sacarina sódica}

\subsubsection{Ciclamato de sódio}

A recristalização destes edulcorantes foi realizada para a retirada de possíveis impurezas que poderiam estar presentes na amostra de origem comercial. Após, foi feita a caracterização dos compostos por espectroscopia na região do infravermelho. Na Figura 3 apresentam-se os espectros do ciclamato de sódio recristalizado (ciclamato $\mathrm{Na} \mathrm{Rec}$ ) e do edulcorante comercial (ciclamato $\mathrm{Na}$ Com).

Como pode ser observado na Figura 3, tanto o ciclamato de sódio comercial, quanto o recristalizado apresentam absorção nos mesmos números de onda. As faixas de absorção entre $1230-1120 \mathrm{~cm}^{-1}$, são para compostos derivados de ácidos sulfônicos (ácido ciclâmico), no caso o ciclamato de sódio. Estes ácidos hidratam-se rapidamente, gerando bandas largas, provavelmente resultantes da formação de sais de hidrônio-sulfonato na região ${ }^{33}$ citada.

No entanto, para melhor avaliar as bandas de absorção obtidas para os ciclamatos, julgou-se importante compará-los com o espectro descrito na literatura ${ }^{50}$. 


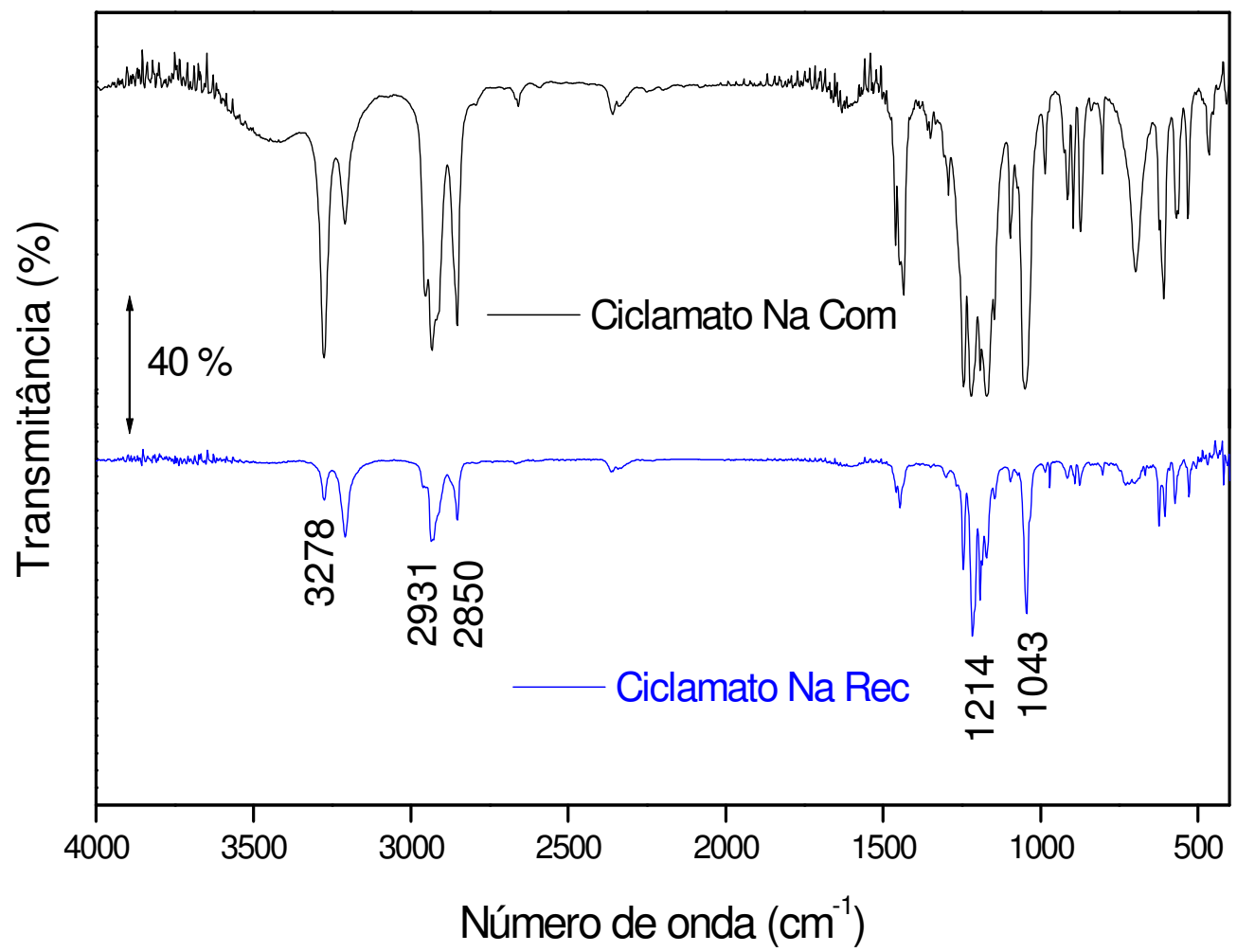

Figura 3. Espectros de absorção na região do infravermelho do ciclamato de sódio comercial e recristalizado.

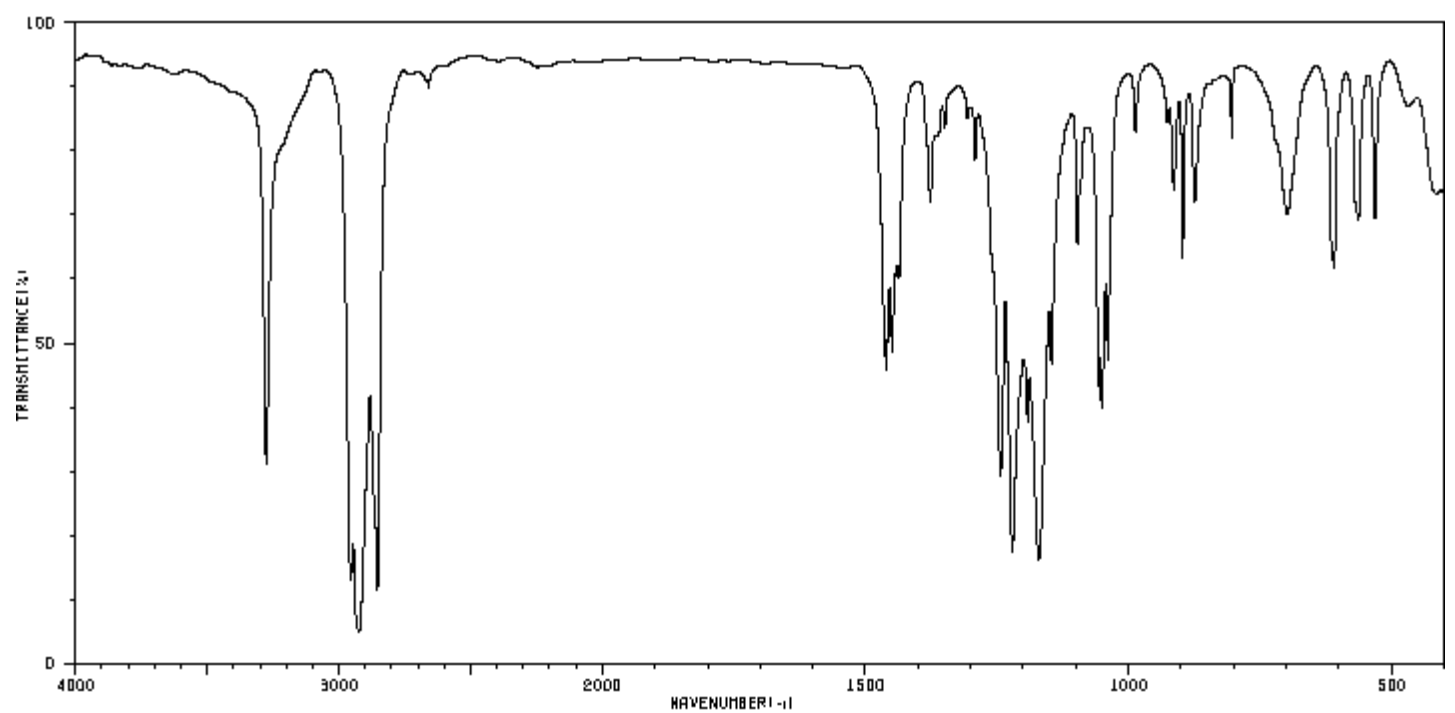

Figura 4. Espectro de absorção na região do infravermelho do ciclamato de sódio ${ }^{50}$. 
O espectro da Figura 4, é bastante semelhante aos espectros para os sais comercial e recristalizado da Figura 3. Portanto, pode-se concluir que os sais apresentam elevado grau de pureza.

Após a realização da recristalização do ciclamato de sódio, foram feitos os estudos termoanalíticos e a caracterização dos mesmos.

\subsubsection{Sacarina Sódica}

Com os mesmos objetivos, o procedimento para a recristalização da sacarina sódica também foi realizado. A Figura 5 apresenta o espectro de absorção na região do infravermelho da sacarina sódica comercial (sacarina $\mathrm{Na}$ Com) e recristalizada (sacarina $\mathrm{Na} \mathrm{Rec).}$

Como pode ser observada na Figura 5, tanto a sacarina sódica comercial, quanto a recristalizada apresentaram absorção nos mesmos números de onda. Os espectros de compostos nos quais o grupo $\mathrm{C}=\mathrm{S}$ está ligado a um átomo de nitrogênio mostram uma banda de absorção na região habitual de deformação axial de $\mathrm{C}=\mathrm{S}$ e várias outras em ampla região de $1563-700 \mathrm{~cm}^{-1}$ que são atribuídas à interação entre as deformações axiais de $\mathrm{C}=\mathrm{S}$ e de $\mathrm{C}-\mathrm{N}$. Também apresentam bandas na região de $3100-3500 \mathrm{~cm}^{-1}$ indicando presença de água nas amostras.

Para melhor avaliar as bandas de absorção obtidas para as sacarinas, julgouse importante compará-los com o espectro descrito na literatura ${ }^{50}$. 


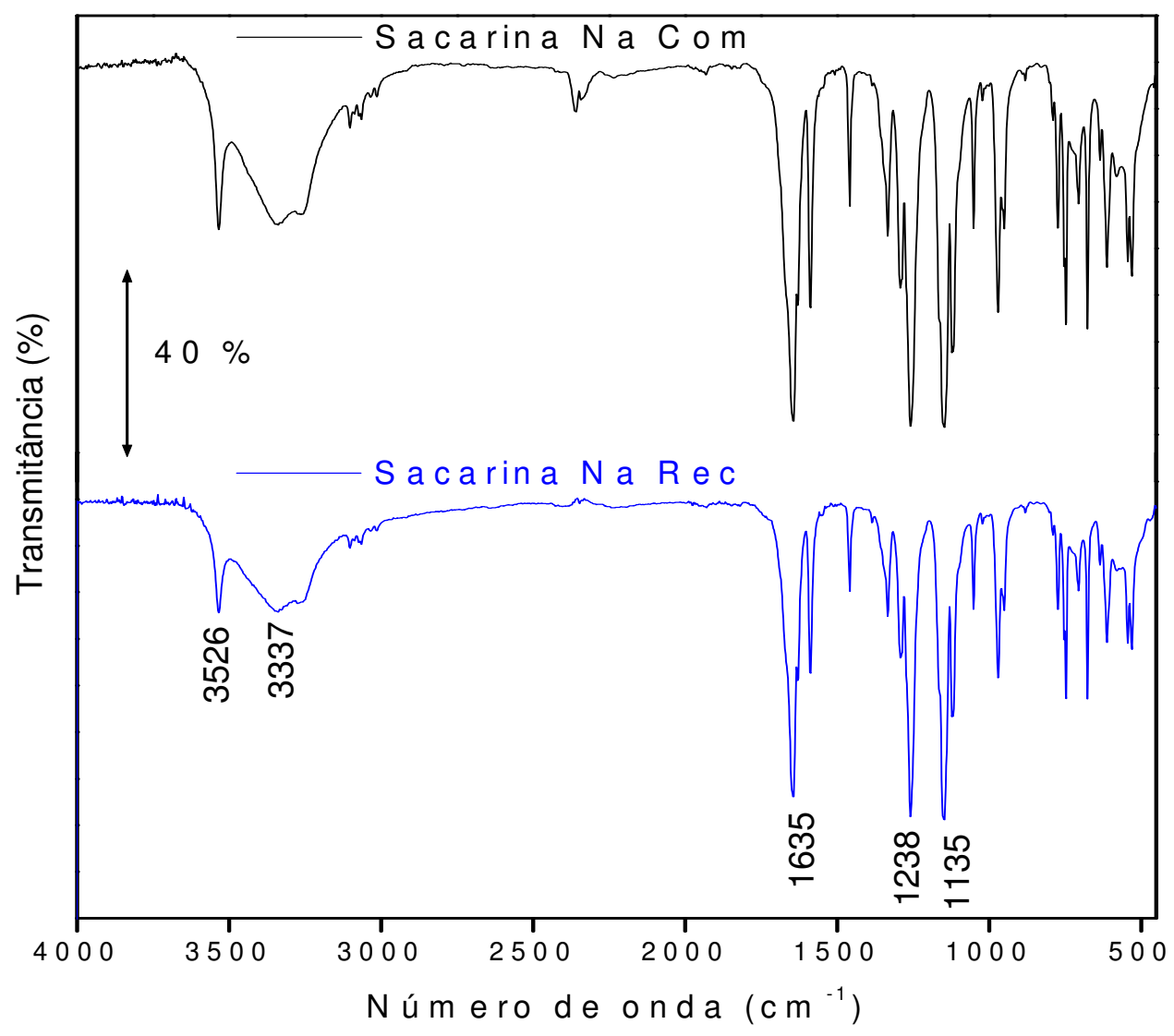

Figura 5. Espectro de absorção na região do infravermelho da sacarina sódica comercial e da recristalizada.

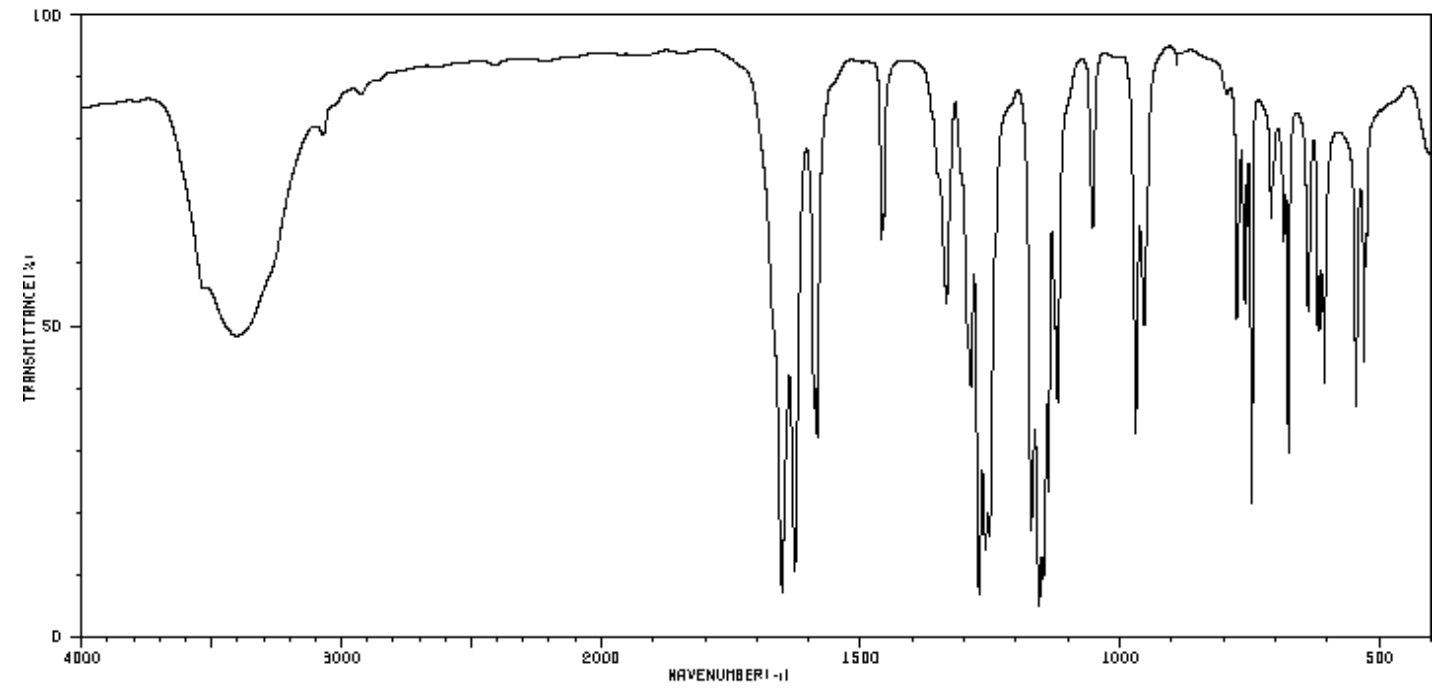

Figura 6. Espectro de absorção na região do infravermelho de sacarina sódica ${ }^{50}$. 
Os picos de absorção mais intensos encontrados nas sacarinas sódicas comercial e recristalizadas foram concordantes com os encontrados na Figura 6, sugerindo pureza significativa em ambos os casos.

\subsection{Preparação da Sacarina Ácida}

A sacarina (sacarina $H$ ) foi preparada a partir da sacarina sódica, e para a confirmação da preparação deste composto, foi realizado a caracterização deste edulcorante por espectroscopia na região do infravermelho, como mostra a Figura 7.

A Figura 7 apresenta a maioria dos picos entre $1563-700 \mathrm{~cm}^{-1}$ que puderam ser vistos nos espectros de IV da sacarina sódica. O espectro obtido foi comparado com um da sacarina (sacarina $\mathrm{H}$ ) existente na literatura ${ }^{50}$, Figura 8 , apresentando alterações em torno de $3500-1722 \mathrm{~cm}^{-1}$ e na região de $1500-700 \mathrm{~cm}^{-1}$ evidenciando a formação do ácido, com alterações na hidratação e nas ligações $\mathrm{C}=\mathrm{S}$ e $\mathrm{C}-\mathrm{N}^{33}$, respectivamente.

A semelhança entre os espectros nas Figuras 7 e 8 , sugerem que a sacarina $\mathrm{H}$ foi obtida. 


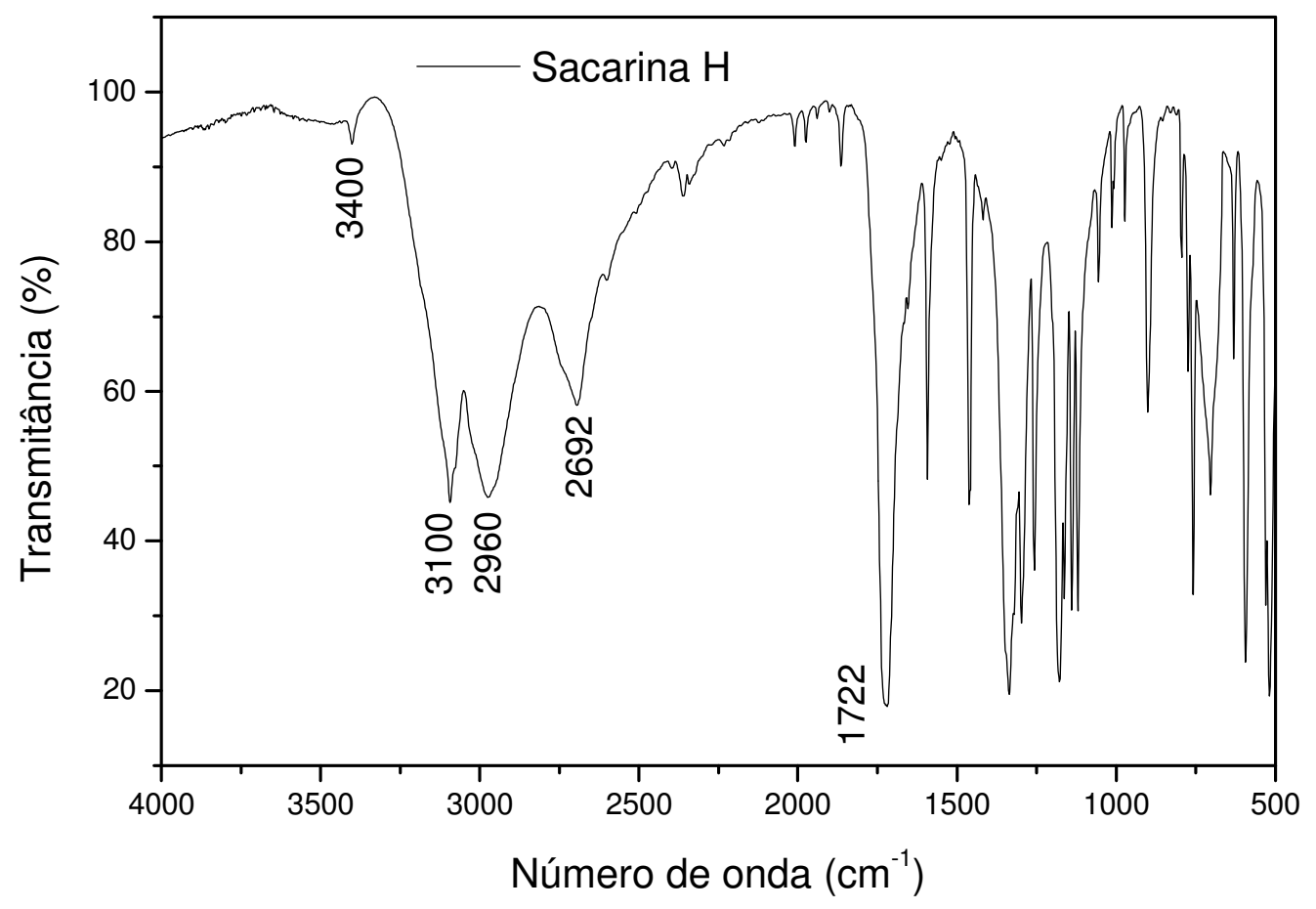

Figura 7. Espectro de absorção na região do infravermelho da sacarina.

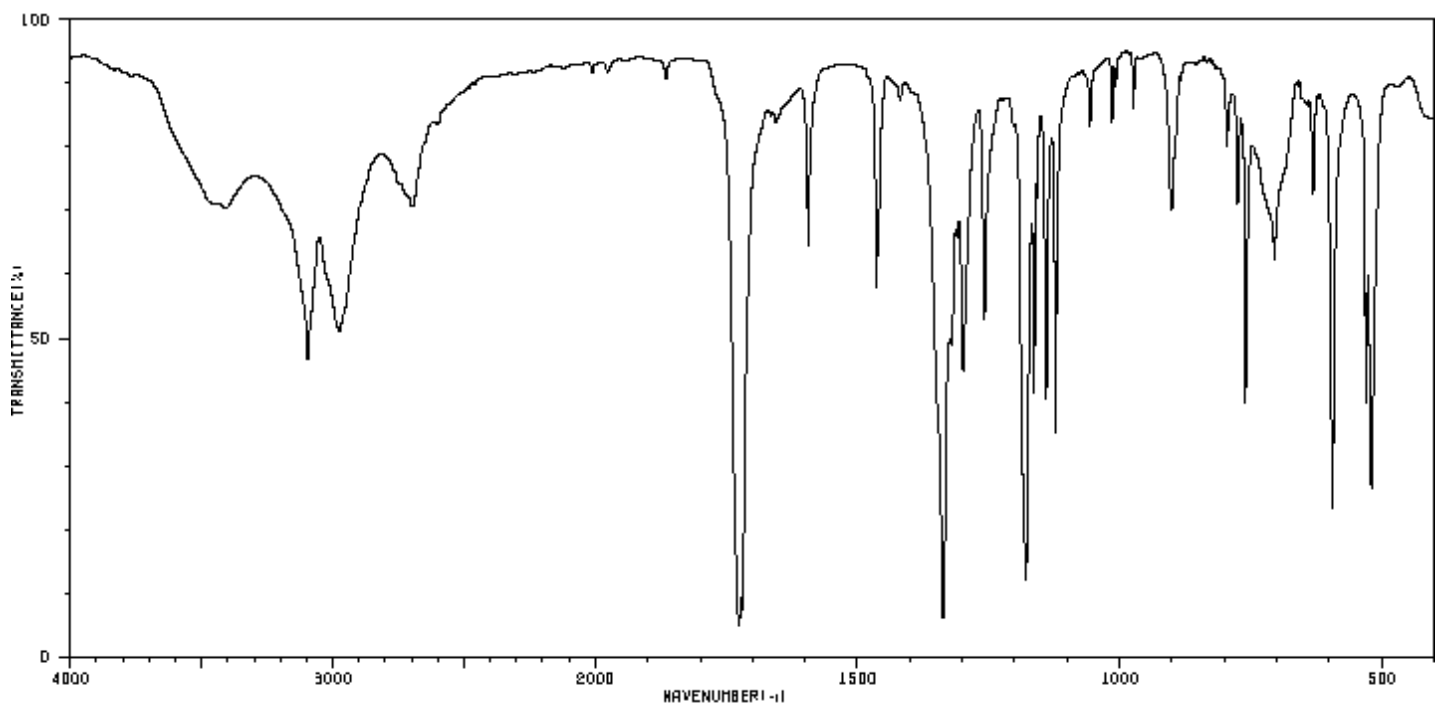

Figura 8. Espectro de absorção na região do infravermelho da sacarina ${ }^{50}$. 


\subsection{Caracterização dos edulcorantes por Análise Elementar (EA)}

As amostras foram submetidas à análise elementar anteriormente aos estudos termoanalíticos comparando-se as quantidades de carbono (C), hidrogênio (H) e nitrogênio $(\mathrm{N})$ experimentais e calculados presentes nos edulcorantes. Os resultados estão apresentados na Tabela 2.

Tabela 2. Teores de carbono $(\mathrm{C})$, hidrogênio $(\mathrm{H})$ e nitrogênio $(\mathrm{N})$ experimentais e calculados para os respectivos edulcorantes

\begin{tabular}{|c|c|c|c|c|c|c|}
\hline \multirow{2}{*}{ Edulcorante } & \multicolumn{6}{|c|}{ Experimental (calculado) (\%) } \\
\hline & \multicolumn{2}{|c|}{ C } & \multicolumn{2}{|c|}{$\mathbf{H}$} & \multicolumn{2}{|c|}{$\mathbf{N}$} \\
\hline $\begin{array}{c}\text { Acessulfame-K } \\
\left(\mathrm{C}_{4} \mathrm{H}_{4} \mathrm{KNO}_{4} \mathrm{~S}\right)\end{array}$ & 24,12 & $(23,85)$ & 2,09 & $(2,01)$ & 7,04 & $(6,96)$ \\
\hline $\begin{array}{l}\text { Aspartame } \\
\left(\mathrm{C}_{14} \mathrm{H}_{18} \mathrm{~N}_{2} \mathrm{O}_{5}\right)\end{array}$ & 55,08 & $(55,31)$ & 6,08 & $(6,42)$ & 9,30 & $(9,92)$ \\
\hline $\begin{array}{l}\text { Ciclamato Sódio Com. } \\
\qquad\left(\mathrm{C}_{6} \mathrm{H}_{12} \mathrm{NNaO}_{3} \mathrm{~S}\right)\end{array}$ & 35,53 & $(35,81)$ & 3,42 & $(6,01)$ & 6,96 & $(6,96)$ \\
\hline $\begin{array}{l}\text { Ciclamato Sódio Rec. } \\
\qquad\left(\mathrm{C}_{6} \mathrm{H}_{12} \mathrm{NNaO}_{3} \mathrm{~S}\right)\end{array}$ & 35,83 & $(35,81)$ & 5,52 & $(6,01)$ & 7,00 & $(6,96)$ \\
\hline $\begin{array}{c}\text { Esteviosídeo } \\
\left(\mathrm{C}_{38} \mathrm{H}_{60} \mathrm{O}_{18}\right)\end{array}$ & 51,52 & $(44,45)$ & 5,03 & $(5,88)$ & - & - \\
\hline $\begin{array}{c}\text { Sacarina H } \\
\left(\mathrm{C}_{7} \mathrm{H}_{4} \mathrm{NO}_{3} \mathrm{~S}\right)\end{array}$ & 45,74 & $(45,89)$ & 3,09 & $(2,75)$ & 7,66 & $(7,65)$ \\
\hline $\begin{array}{l}\text { Sacarina Na Com. } \\
\left(\mathrm{C}_{7} \mathrm{H}_{4} \mathrm{NNaO}_{3} \mathrm{~S} .2 \mathrm{H}_{2} \mathrm{O}\right)\end{array}$ & 34,91 & $(34,85)$ & 3,05 & $(3,34)$ & 5,85 & $(5,80)$ \\
\hline $\begin{array}{l}\text { Sacarina Na Rec. } \\
\left(\mathrm{C}_{7} \mathrm{H}_{4} \mathrm{NNaO}_{3} \mathrm{~S} . \mathrm{H}_{2} \mathrm{O}\right)\end{array}$ & 38,43 & $(37,66)$ & 1,67 & $(2,71)$ & 6,52 & $(6,27)$ \\
\hline
\end{tabular}

Observando a Tabela 2, pode-se dizer que as quantidades de C, $\mathrm{H}$ e $\mathrm{N}$ estão de acordo com as fórmulas propostas, com exceção do teor de $\mathrm{H}$ do ciclamato de sódio comercial, no qual pode ter ocorrido algum erro instrumental.

No caso do edulcorante esteviosídeo, a diferença no teor de $\mathrm{C}$ deve-se à mistura da amostra com outros edulcorantes como rebaudiosídeo A e outras substâncias denominadas "edulcorantes totais" não divulgados pelo fabricante. 
4.4 Estudos termoanalíticos e caracterização de intermediários e dos resíduos de cada edulcorante

4.4.1 Termogravimetria (TG), Termogravimetria Derivada (DTG) e Análise Térmica Diferencial (DTA) e sua respectiva caracterização

\subsubsection{Acessulfame-K}

As curvas TG/ DTG e TG/DTA obtidas sob atmosfera de ar para os edulcorantes investigados neste trabalho estão apresentadas na Figura 9.

Nas Figuras 9 a e b estão as curvas TG/DTG e TG/DTA obtidas do acessulfame-K. Na Tabela 3, são apresentados os intervalos de temperatura, atribuição dos eventos observados e perdas de massa e picos DTA envolvidas na decomposição do mesmo. 


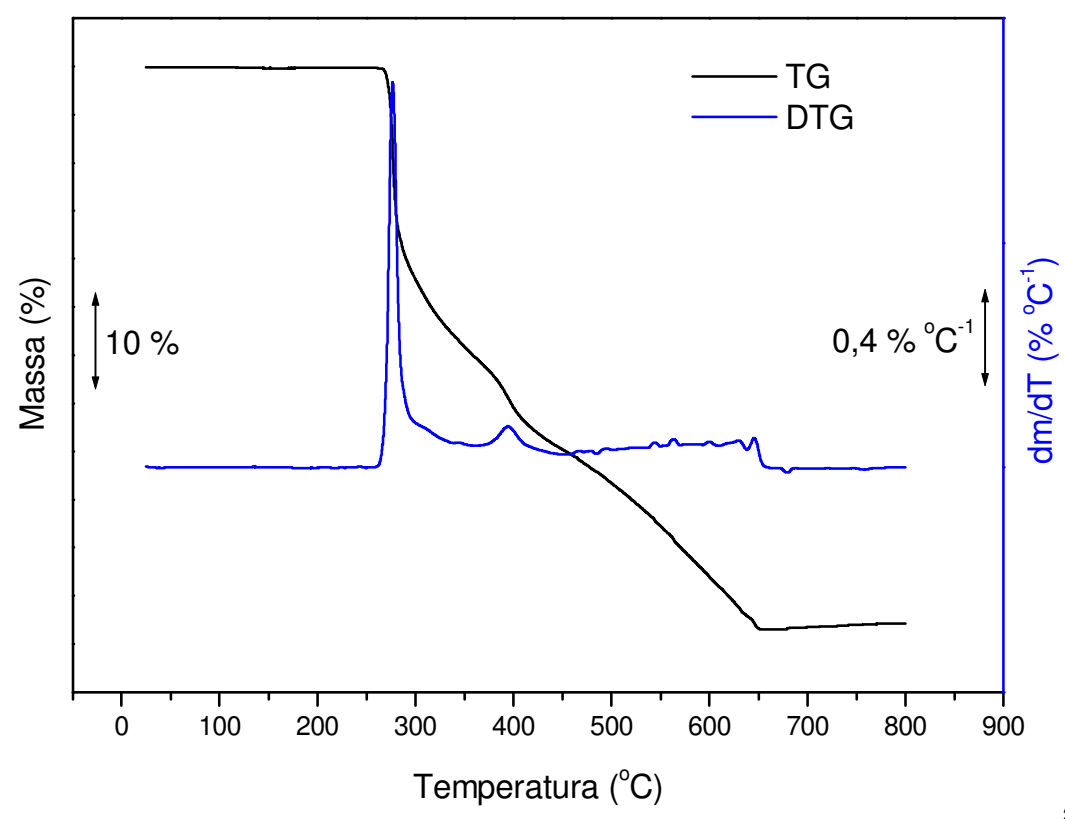

a

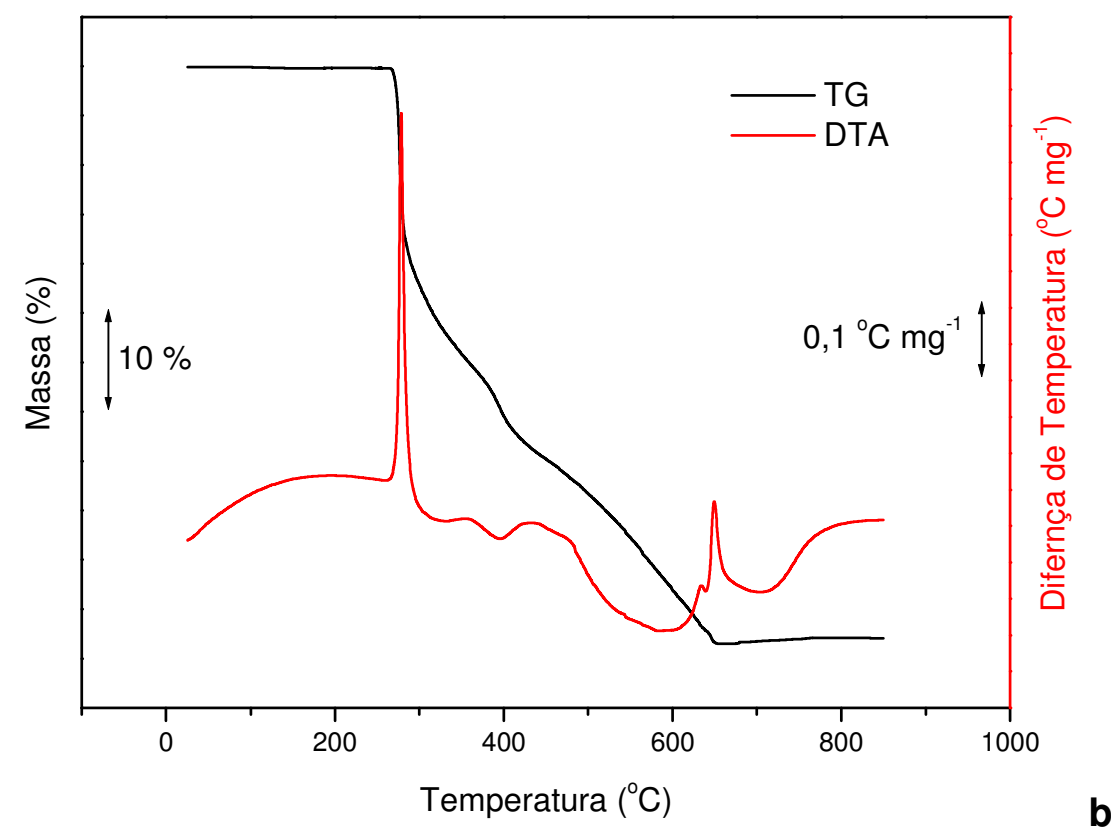

Figura 9. Curvas TG/DTG (a) e TG/DTA (b) do acessulfame-K, obtidas sob atmosfera de ar. Vazão de $100 \mathrm{~mL} \mathrm{~min}^{-1}$, massa de amostra de $4 \mathrm{mg}$, razão de aquecimento de 10 ${ }^{\circ} \mathrm{C} \mathrm{min}^{-1}$ e suporte de amostra de alumina. 
Tabela 3. Atribuições de eventos térmicos, intervalos de temperatura e perdas de massa observados nas curvas TG/DTG do edulcorante acessulfame-K sob atmosfera de ar

\begin{tabular}{ccccc}
\hline Processo & $\begin{array}{c}\text { Intervalo temperatura } \\
\left({ }^{\circ} \mathrm{C}\right)\end{array}$ & $\begin{array}{c}\text { Perda de massa ou } \\
\text { resíduo (\%) } \\
\text { Experimental }\end{array}$ & (Calculado) & Picos DTA $\left({ }^{\circ} \mathbf{C}\right)$ \\
\hline $\mathrm{Dec}^{\mathbf{a}} \rightarrow \mathrm{MC}^{\mathbf{b}}$ & $258,5-450,2$ & 39,7 & ----- & 278,0 \\
Queima do $\mathrm{MC}^{\mathbf{b}}\left(\mathrm{K}_{2} \mathrm{SO}_{4}\right)$ & $450,2-658,3$ & 18,7 & ---- & 633,1 \\
Resíduo $\left(\mathrm{K}_{2} \mathrm{SO}_{4}\right)$ & 658,3 & 42,1 & $(43,0)$ & 650,2 \\
\hline
\end{tabular}

Em que: $\mathbf{a}=$ decomposição (Dec); $\mathbf{b}=$ material carbonizado (MC)

Sob ar, o primeiro processo de decomposição do acessulfame-K ocorreu em 258,5 e $450,2^{\circ} \mathrm{C}$, sugerindo relativamente uma alta estabilidade térmica, resultando em um resíduo carbonizado. Em seguida, o resíduo carbonizado queima entre 450,2 e $658,3{ }^{\circ} \mathrm{C}$ produzindo sulfato de potássio $\left(\mathrm{K}_{2} \mathrm{SO}_{4}\right)$ como resíduo ao final da curva TG. Após a queima do material carbonizado, foi obtido um resíduo acinzentado de $42,08 \%$, próximo ao valor calculado para $\left(\mathrm{K}_{2} \mathrm{SO}_{4}\right)$ de $43,0 \%$.

O resíduo obtido a $658{ }^{\circ} \mathrm{C}$ foi caracterizado por IV e DRX, tendo sido confirmada a presença de sulfato de potássio em ambos os casos. $\mathrm{O} \mathrm{K}_{2} \mathrm{SO}_{4}$ também foi identificado nos resíduos obtidos a 356,8 e 450,2 ${ }^{\circ} \mathrm{C}$, usando-se IV, conforme apresentado na Figura 10, que trás os espectros para os resíduos nas diferentes temperaturas, e para o padrão de $\mathrm{K}_{2} \mathrm{SO}_{4}$ da biblioteca Aldrich FT-IR ${ }^{49}$. 


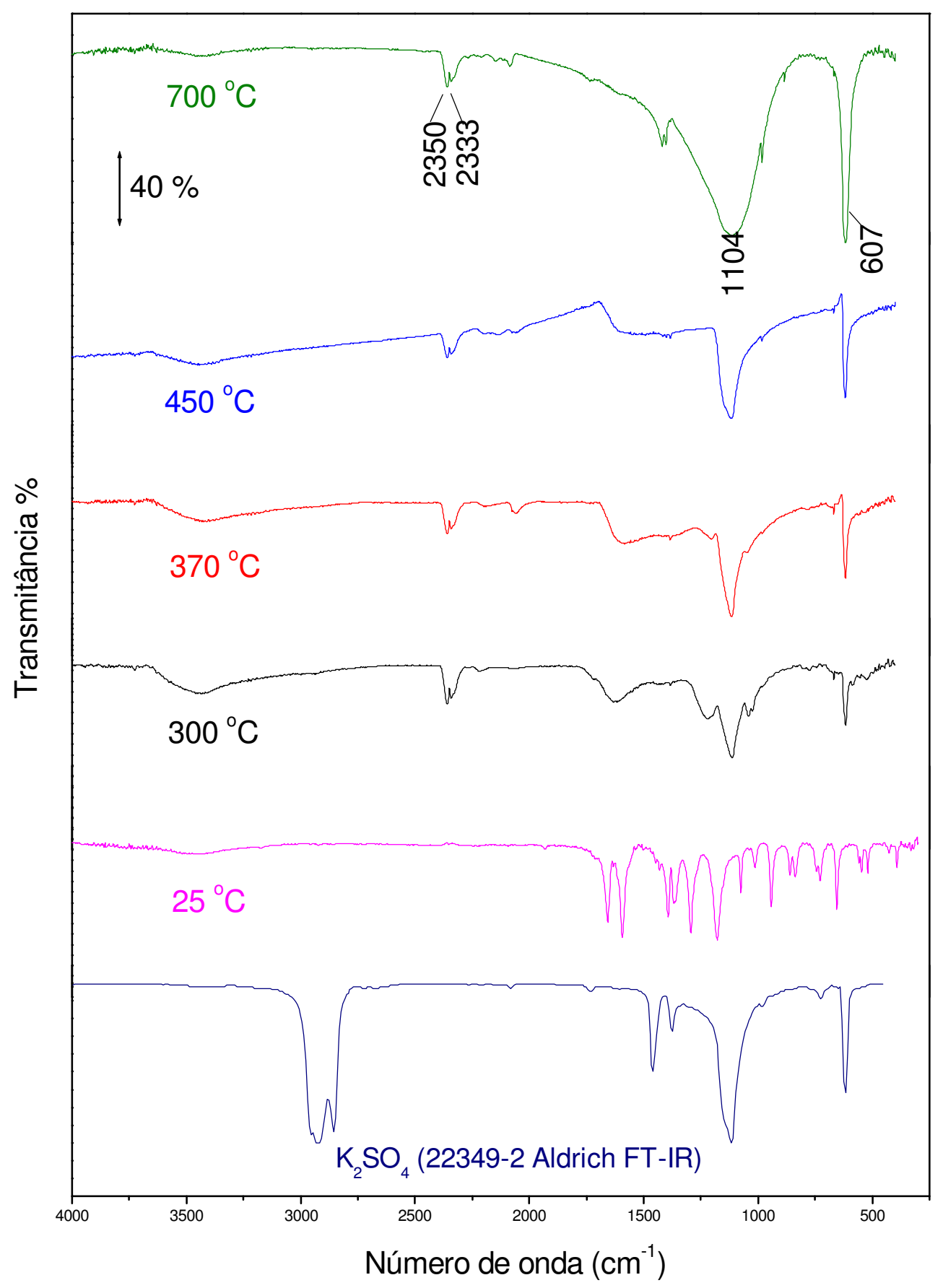

Figura 10. Espectro de absorção na região infravermelho dos intermediários e do resíduo do acessulfame-K.

Observando-se a Figura 10 acima, pôde-se notar a presença de dois picos principais (em torno de 1100 e $600 \mathrm{~cm}^{-1}$ ) de absorção na mesma região do espectro de sulfato de potássio $\left(\mathrm{K}_{2} \mathrm{SO}_{4}\right)$ desde sua primeira decomposição a $300{ }^{\circ} \mathrm{C}$. No 
entanto, as amostras apresentavam outros picos que não puderam ser caracterizados por IR. Então, julgou-se necessário a caracterização do mesmo, por difração de raios X, Figura 11.

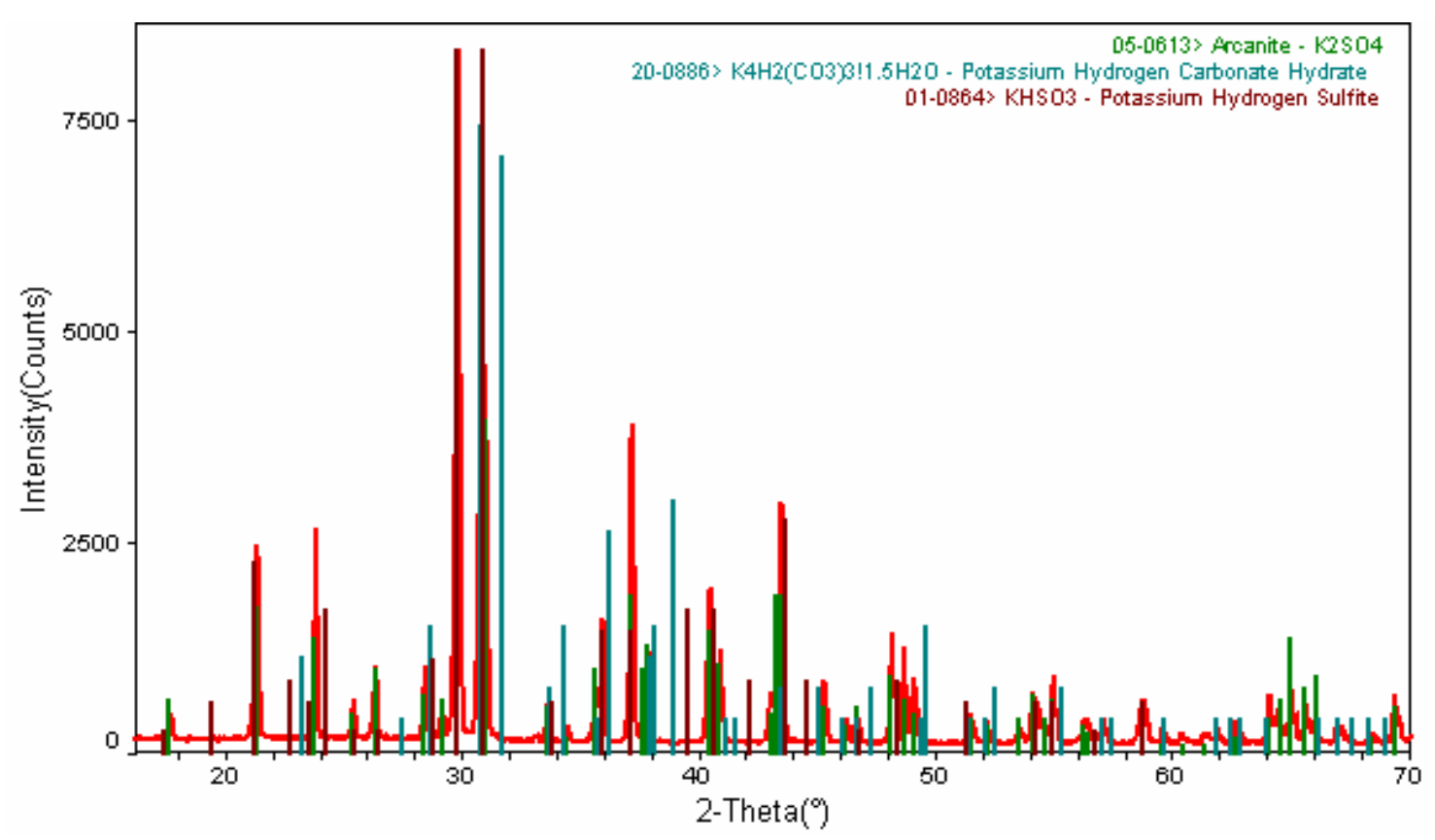

Figura 11. Difratograma de raios $\mathrm{X}$ do resíduo de acessulfame-K a $700 \stackrel{\circ}{\mathrm{C}}$.

O difratograma de raios $\mathrm{X}$ apresentado na Figura 11 confirma a formação de $\mathrm{K}_{2} \mathrm{SO}_{4}$ nesta temperatura como produto de decomposição térmica do acessulfame-K.

Os espectros da biblioteca Aldrich FT-IR ${ }^{49}$ e do Integrated Spectral Database System of Organic Compounds ${ }^{50}$ apresentam dois picos de absorbância intensos e sobrepostos na região de $2900 \mathrm{~cm}^{-1}$ característicos do Nujol, que é utilizado no preparo das amostras ${ }^{51}$. Portanto, todos os espectros retirados da literatura e utilizados como referência neste trabalho apresentam estes picos de absorbância, que devem ser desconsiderados para a interpretação dos resultados. 


\subsubsection{Aspartame}

Nas Figuras 12 a e b são apresentadas as curvas TG/DTG e TG/DTA obtidas para o aspartame e abaixo na Tabela 4, são apresentados os intervalos de temperatura, atribuição dos eventos observados e perdas de massa envolvidas na decomposição do mesmo. 

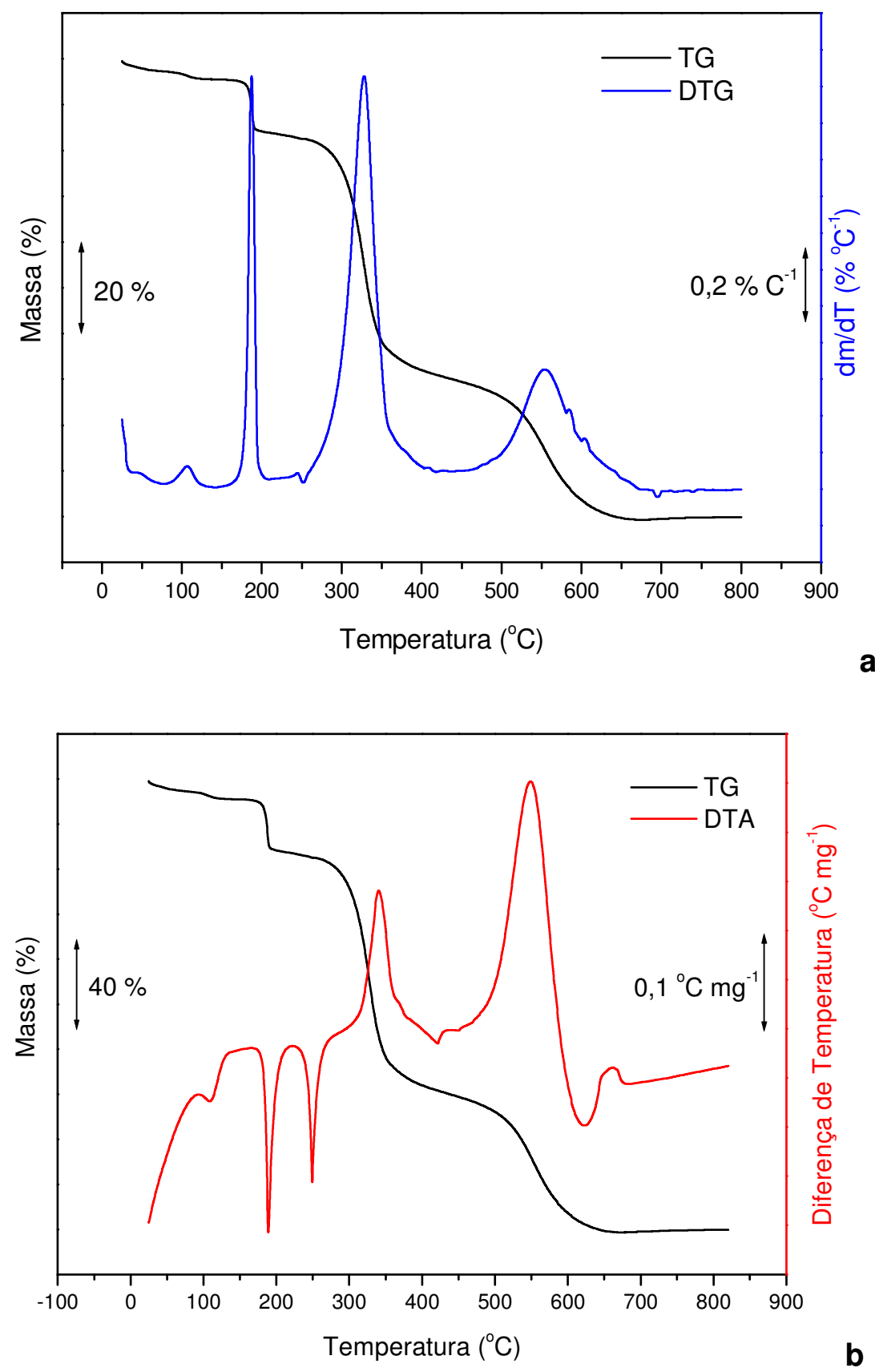

Figura 12. Curvas TG/DTG (a) e TG/DTA (b)do aspartame obtidas sob atmosfera de ar. Vazão de $100 \mathrm{~mL} \mathrm{~min}^{-1}$, massa de amostra de $4 \mathrm{mg}$, razão de aquecimento de $10{ }^{\circ} \mathrm{C} \mathrm{min}^{-1}$ e suporte de amostra de alumina. 
Tabela 4. Atribuições de eventos térmicos, intervalos de temperatura e perdas de massa observados nas curvas TG/DTG do edulcorante aspartame sob atmosfera de ar

\begin{tabular}{|c|c|c|c|c|}
\hline \multirow[t]{2}{*}{ Processo } & \multirow[t]{2}{*}{$\begin{array}{c}\text { Intervalo } \\
\text { temperatura }\left({ }^{\circ} \mathrm{C}\right)\end{array}$} & \multicolumn{2}{|c|}{$\begin{array}{l}\text { Perda de massa } \\
\text { ou resíduo (\%) }\end{array}$} & \multirow[t]{2}{*}{ Picos DTA $\left({ }^{\circ} \mathrm{C}\right)$} \\
\hline & & Experimental & (Calculado) & \\
\hline Desidratação & $24,8-76,8$ & 2,7 & $(2,9)$ & ----- \\
\hline Desidratação & $76,8-142,4$ & 1,8 & $(1,5)$ & 109,7 \\
\hline Decomposição & $142,4-210,5$ & 11,7 & ----- & 190,3 \\
\hline Decomposição & $210,5-257,2$ & 1,3 & ------ & 249,8 \\
\hline $\mathrm{Dec}^{\mathrm{a}} \rightarrow \mathrm{MC}^{\mathrm{b}}$ & $257,2-421,2$ & 51,6 & ------ & 340,3 \\
\hline Queima do $\mathrm{MC}^{\mathrm{b}}$ & $421,2-785,7$ & 31,0 & ------ & 548,2 \\
\hline Resíduo & 785,7 & 0 & 0 & ------ \\
\hline
\end{tabular}

Em que: $\mathbf{a}=$ decomposição (Dec); $\mathbf{b}$ = material carbonizado (MC)

As curvas obtidas sob atmosfera de ar para o aspartame, apresentaram seis eventos de decomposição térmica, estando de acordo com os resultados demonstrados por Simêncio ${ }^{10}$ em 2005. Estes eventos foram caracterizados por Conceição em 2004, que descreveu a presença de apenas cinco eventos térmicos para este edulcorante, não sendo observado o quarto evento ocorrido entre 210,5 e $257,2{ }^{\circ} \mathrm{C}$. Essas diferenças podem ser atribuídas ao uso de equipamentos de fabricantes diferentes, com diferenças marcantes na geometria do forno e de acessórios, como também do edulcorante estudado ser de outro fornecedor, ou impureza do composto. Uma vez que a perda de massa é muito pequena, é muito difícil realizar uma caracterização segura do resíduo ou do volátil.

Como os intervalos de decomposição definidos, foram feitas as caracterizações dos intermediários possíveis por IV, como mostra a Figura 13. O quinto e o sexto eventos não puderam ser caracterizados devido à permeação da amostra no suporte de amostra em alumina, usado nos experimentos preparativos. 
Apesar da realização dos espectros de IR dos intermediários do aspartame, foi difícil verificar a formação dos mesmos com os descritos na literatura ${ }^{40}$ com os padrões do Scifinder de fenilalanina, por exemplo, Figura 14.

A partir das Figuras 13 e 14, observa-se que há material orgânico até $200{ }^{\circ} \mathrm{C}$. A partir de $430{ }^{\circ} \mathrm{C}$, o espectro sugere material decomposto. Mudanças nas regiões de $3000-2500 \mathrm{~cm}^{-1}$ evidenciam desidratação.

O material obtido a $90{ }^{\circ} \mathrm{C}$ apresenta semelhanças com o espectro da fenilalanina, da literatura. No entanto, como a amostra apresentava outros picos que não puderam ser caracterizados por IR, julgou-se necessária à caracterização do mesmo por difração de raios X, Figura 15. 


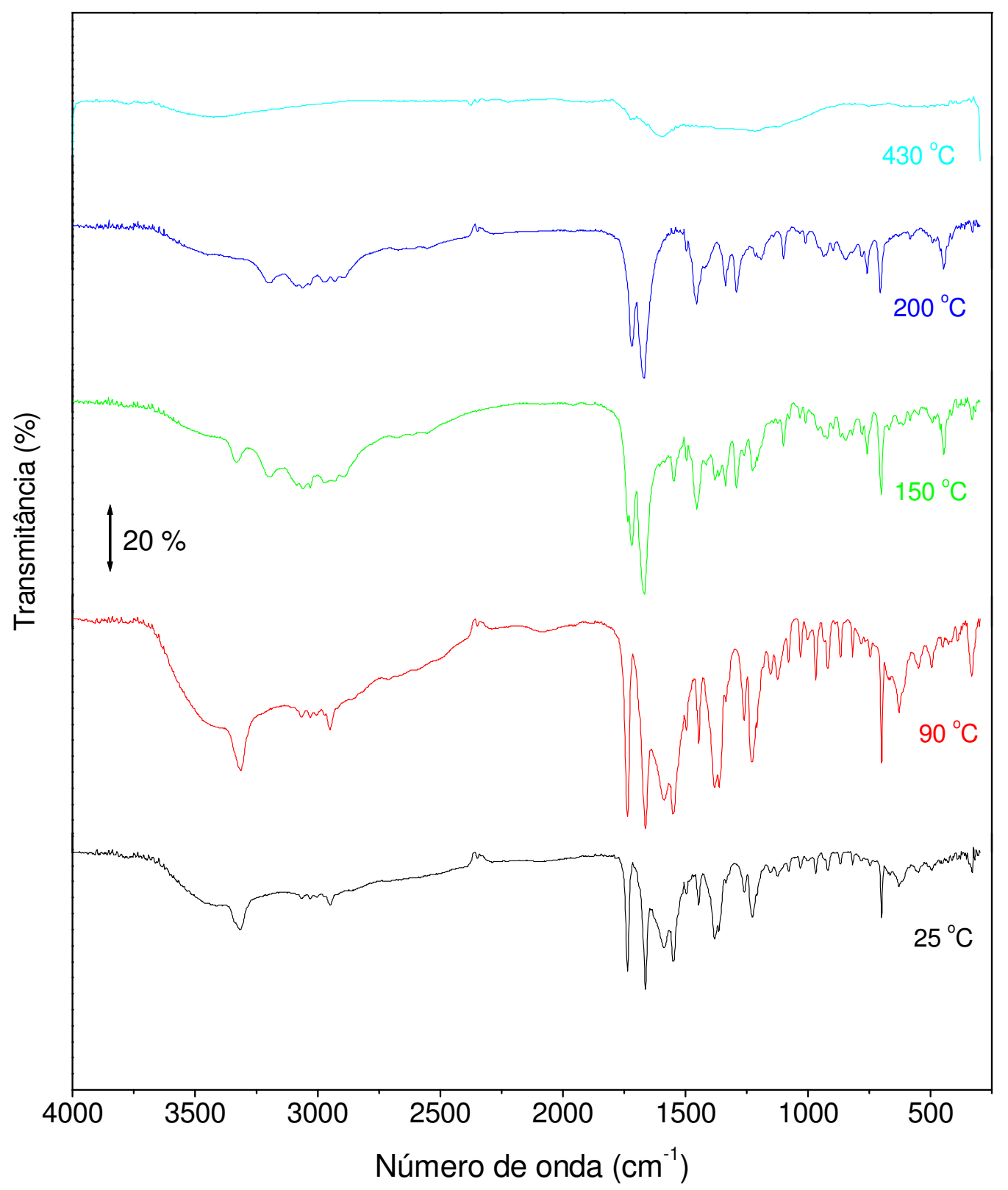

Figura 13. Espectros de absorção na região infravermelho dos resíduos de aspartame em diferentes temperaturas. 


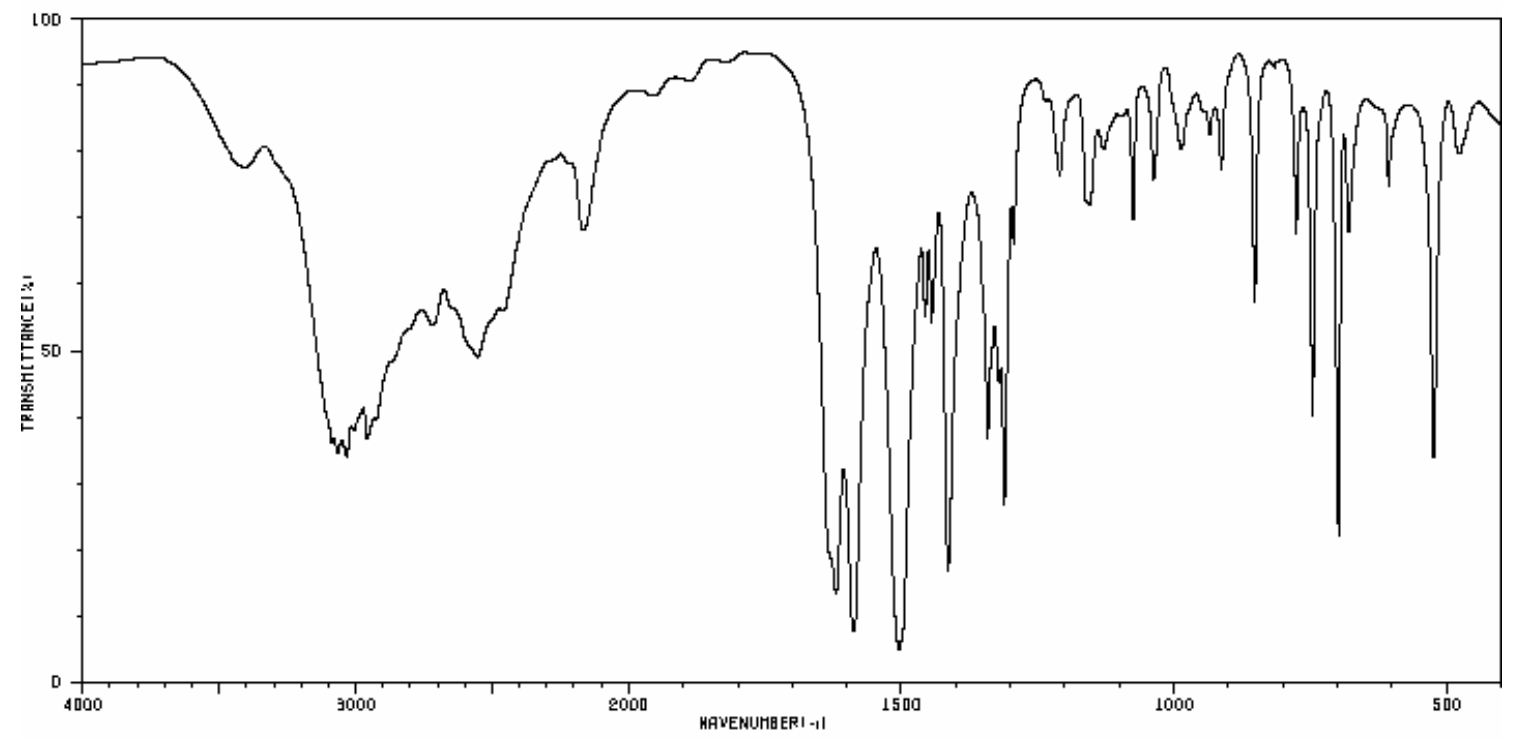

Figura 14. Espectro de absorbância na região do infravermelho da fenilalanina ${ }^{50}$.

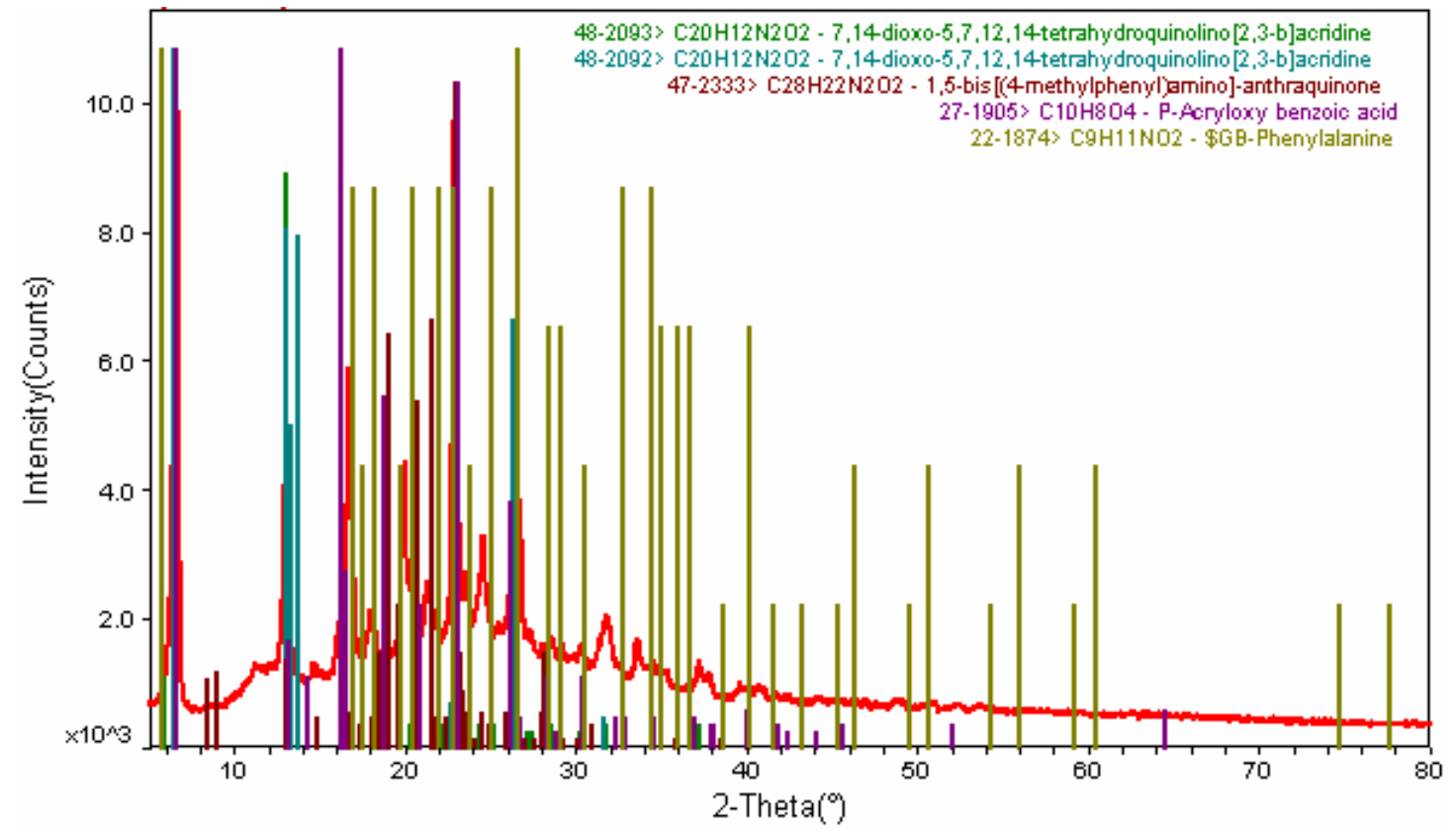

Figura 15. Difratograma de raios $\mathrm{X}$ do resíduo de aspartame a $200{ }^{\circ} \mathrm{C}$. 
Como pode ser observado na Figura 15, o difratograma de raios $\mathrm{X}$ a $200{ }^{\circ} \mathrm{C}$ confirma a formação fenilalanina nesta temperatura como produto de decomposição térmica do aspartame. No entanto, existem outros produtos presentes na amostra.

Devido a grande quantidade de material carbonizado, não foi possível a caracterização de todas as substâncias presentes, tão pouco dos demais intermediários.

A caracterização destes eventos foi realizada por Conceição ${ }^{40}$, utilizando a termogravimetria, como também outras técnicas. Este trabalho descreveu a presença de apenas cinco eventos térmicos na decomposição do aspartame, não sendo observado o evento ocorrido entre 210,53 e $257,20^{\circ} \mathrm{C}$, aproximadamente. $\mathrm{O}$ primeiro e o segundo eventos foram relacionados à desidratação do aspartame. Já o terceiro foi atribuído estequiometricamente à decomposição do aspartame ocorrida à volatilização do metanol. O quinto evento foi atribuído à decomposição da dicetopiperazina, causada pela volatilização da fenilalanina metil éster. O sexto evento foi relacionado foi relacionado ao restante da decomposição da dicetopiperazina. Assim, de acordo com os dados termogravimétricos, foi sugerido que após a desidratação do aspartame ocorre sua decomposição, devido à liberação de metanol, isto leva à conversão do aspartame a dicetopiperazina, que consequentemente decompõem-se com a liberação de fenilalanina metil éster ${ }^{10}$.

Vários fatores podem influenciar nos resultados observados neste trabalho, comparando-se com os descritos por Conceição ${ }^{40}$ e Simêncio ${ }^{10}$. Essas diferenças podem ser atribuídas provavelmente ao uso de equipamentos de fabricantes diferentes, com diferenças marcantes na geometria do forno e de acessórios. 


\subsubsection{Ciclamato de sódio}

Nas Figuras 16 a e b , 17 a e b, estão as curvas TG/DTG e TG/DTA obtidas tanto para o ciclamato de sódio comercial, quanto para o recristalizado e na Tabela 5, são apresentados os intervalos de temperatura, atribuição dos eventos observados e perdas de massa envolvidas na decomposição dos mesmos. 

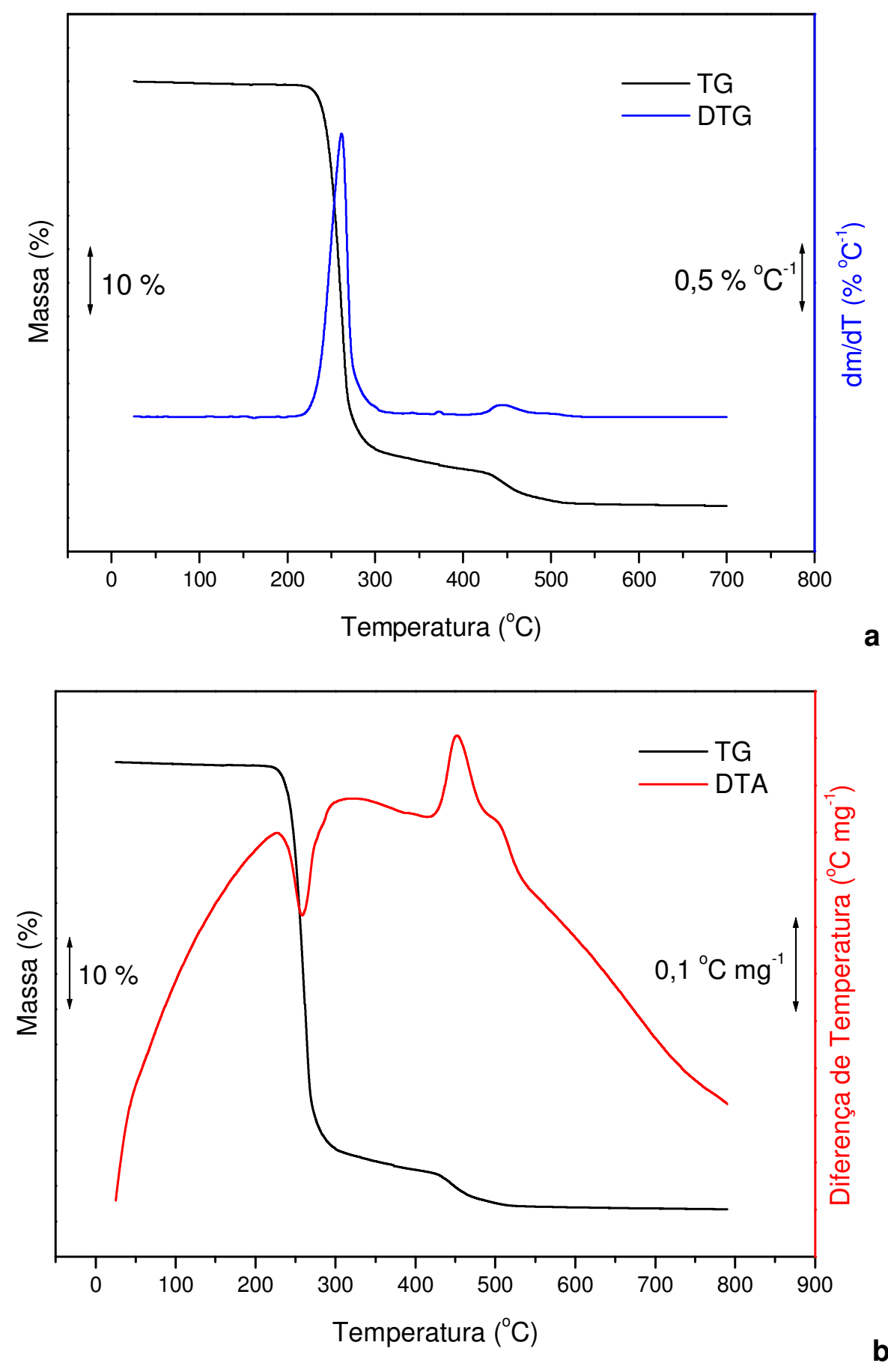

Figura 16. Curvas TG/DTG (a) e TG/DTA (b) do ciclamato de sódio comercial obtidas sob atmosfera de ar. Vazão de $100 \mathrm{~mL} \mathrm{~min}^{-1}$, massa de amostra de $4 \mathrm{mg}$, razão de aquecimento de $10^{\circ} \mathrm{C} \mathrm{min}^{-1}$ e suporte de amostra de alumina. 


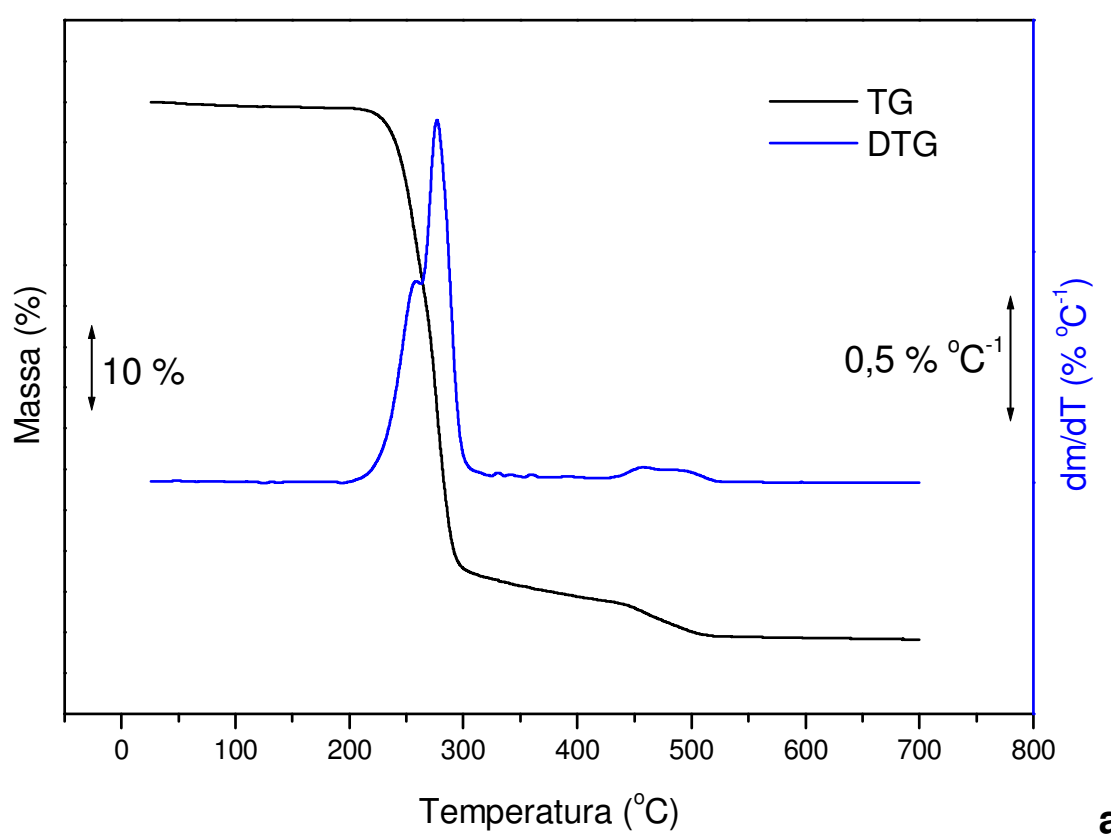

a

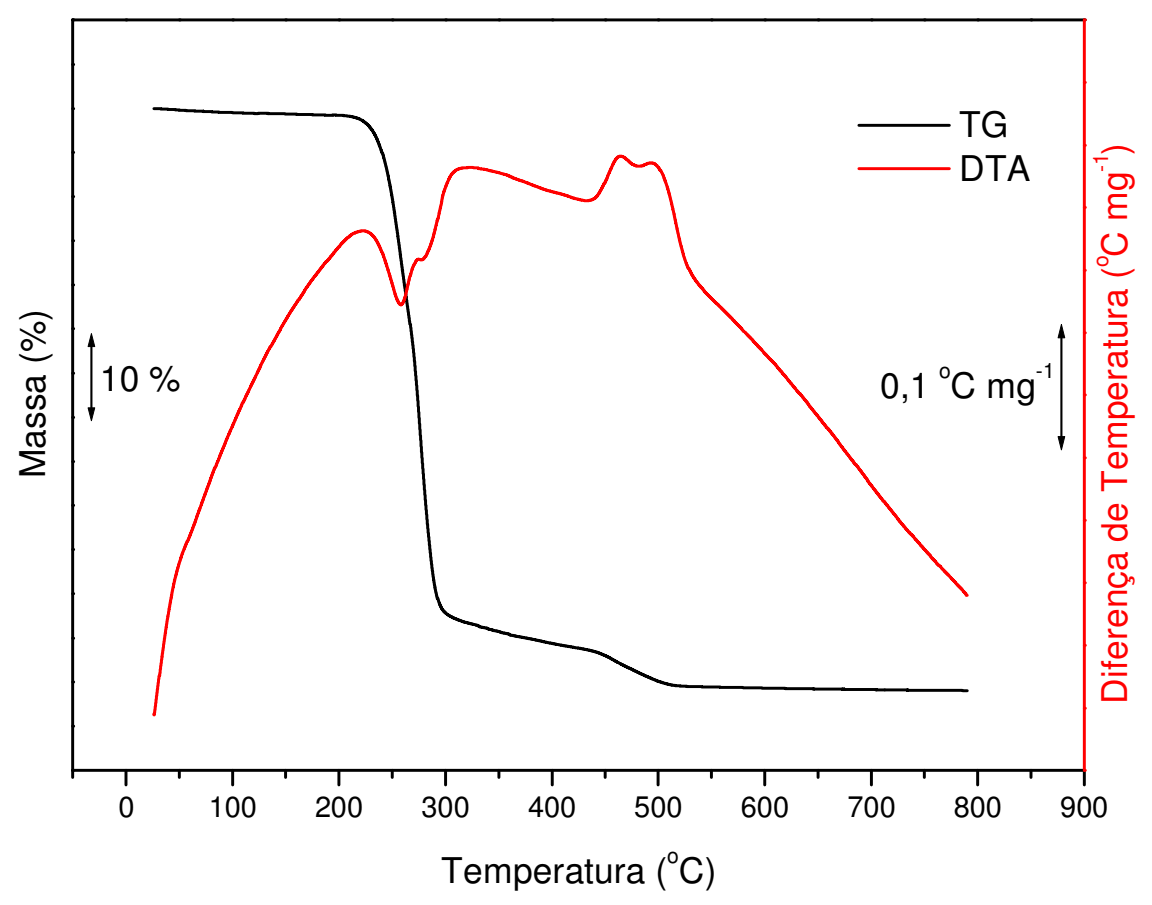

b

Figura 17. Curvas TG/DTG (a), TG e DTA (b) do ciclamato de sódio recristalizado obtidas sob atmosfera de ar. Vazão de $100 \mathrm{~mL} \mathrm{~min}^{-1}$, massa de amostra de $4 \mathrm{mg}$, razão de aquecimento de $10 \stackrel{\circ}{\circ} \min ^{-1}$ e suporte de amostra de alumina. 
Tabela 5. Atribuições de eventos térmicos, intervalos de temperatura e perdas de massa observados nas curvas TG/DTG dos edulcorantes ciclamato de sódio comercial e recristalizado sob atmosfera de ar

\begin{tabular}{|c|c|c|c|c|c|}
\hline \multirow[t]{2}{*}{ Edulcorante } & \multirow{2}{*}{$\begin{array}{c}\text { Processo } \\
\text { Desidratação }\end{array}$} & \multirow{2}{*}{$\begin{array}{c}\begin{array}{c}\text { Intervalo } \\
\text { temperatura } \\
\left({ }^{\circ} \mathrm{C}\right)\end{array} \\
24,1-180,0\end{array}$} & \multicolumn{2}{|c|}{$\begin{array}{l}\text { Perda de massa } \\
\text { ou resíduo (\%) } \\
\text { Experimental (Calculado) }\end{array}$} & \multirow{2}{*}{$\begin{array}{c}\text { Picos } \\
\text { DTA }\left({ }^{\circ} \mathrm{C}\right) \\
----\end{array}$} \\
\hline & & & 0,7 & $(1,7)$ & \\
\hline \multirow{3}{*}{ Comercial } & $\mathrm{Dec}^{\mathrm{a}} \rightarrow \mathrm{MC}^{\mathrm{b}}$ & $180,0-331,9$ & 55,8 & ------ & 259,7 \\
\hline & $\begin{array}{l}\text { Queima do } \mathrm{MC}^{\mathrm{b}} \\
\qquad\left(\mathrm{Na}_{2} \mathrm{SO}_{4}\right)\end{array}$ & $331,9-571,1$ & 6,9 & ------ & 452,4 \\
\hline & Resíduo $\left(\mathrm{Na}_{2} \mathrm{SO}_{4}\right)$ & 571,1 & 36,7 & $(35,3)$ & ------ \\
\hline \multirow{5}{*}{ Recristalizado } & Desidratação & $27,2-180,0$ & 1,1 & $(1,9)$ & ---- \\
\hline & Decomposição & $180,0-260,0$ & 22,3 & ------ & 258,7 \\
\hline & $\mathrm{Dec}^{\mathrm{a}} \rightarrow \mathrm{MC}^{\mathrm{b}}$ & $260,0-323,8$ & 36,2 & ------ & ------ \\
\hline & $\begin{array}{l}\text { Queima do } \mathrm{MC}^{\mathrm{b}} \\
\qquad\left(\mathrm{Na}_{2} \mathrm{SO}_{4}\right)\end{array}$ & $323,8-795,0$ & 7,5 & ------ & 463,5 \\
\hline & Resíduo $\left(\mathrm{Na}_{2} \mathrm{SO}_{4}\right)$ & 575,0 & 34,1 & $(35,3)$ & ------ \\
\hline
\end{tabular}

Em que: $\mathbf{a}=$ decomposição (Dec); $\mathbf{b}$ = material carbonizado (MC)

A curva TG dos ciclamatos revelam uma perda de massa desde o início do experimento a qual deve estar relacionada a água fracamente ligada.

Em ambas as amostras, comercial e recristalizada, a perda se dá entre $24,13-180,0{ }^{\circ} \mathrm{C}$ e $27,16,-180,0{ }^{\circ} \mathrm{C}$ respectivamente. Entretanto, as perdas de massa são de 0,72 e 1,1 \% para os dois casos. A elevada temperatura do final do processo sugere que estas águas não são apenas de umidade e que podem representar resíduo de água de hidratação que não foi eliminada completamente no processo de secagem.

O primeiro processo de decomposição, após a desidratação, tanto do ciclamato comercial quanto do recristalizado, inicia-se após $180{ }^{\circ} \mathrm{C}$, aproximadamente. Em seguida, ambas as amostras se decompuseram gerando um resíduo carbonizado, o qual queima na seqüência, de acordo com os dados da 
Tabela 5. Com a queima do material carbonizado, foi obtido um resíduo de 36,7 e $34,1 \%$, respectivamente, próximos ao valor calculado para $\mathrm{Na}_{2} \mathrm{SO}_{4}$ de $35,3 \%$. A altas temperaturas, pode ocorrer empacotamento da amostra, levando à uma pequena diferença nos percentuais dos resíduos experimentais.

Na curva DTG do ciclamato recristalizado, ficou evidenciado que o processo de decomposição ocorre em mais de uma etapa. Entretanto, sendo os eventos consecutivos, não foi possível isolar os intermediários a $250^{\circ} \mathrm{C}$ para caracterização.

As curvas DTA apresentam eventos concordantes com o que foi descrito para o TG/DTG, sem evidências de fusão ou transição cristalina. A decomposição é representada por picos endotérmicos em torno de $250{ }^{\circ} \mathrm{C}$ e a queima do resíduo carbonizado, por pico exotérmico em torno de $460{ }^{\circ} \mathrm{C}$, nas duas curvas

Os resíduos finais e intermediários do ciclamato comercial e recristalizado foram caracterizados por IR, como mostra a Figura 18. 


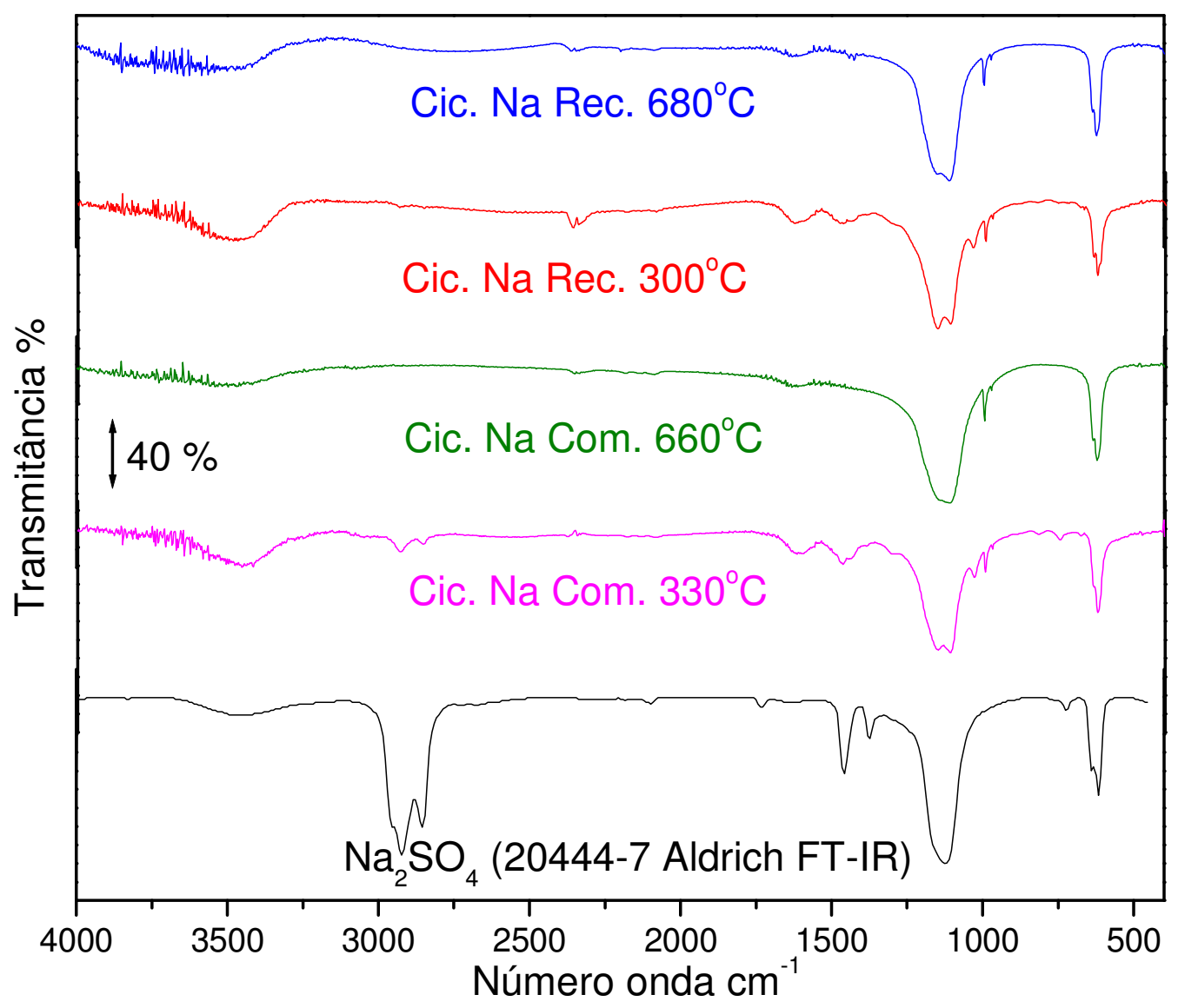

Figura 18. Espectros de absorção na região do infravermelho dos resíduos de ciclamato de sódio comercial e recristalizado em diferentes temperaturas.

Como pode ser visto na Figura 18, os espectros dos resíduos obtidos apresentam semelhanças com o de sulfato de sódio, da literatura ${ }^{49}$. Espectros de IR dos resíduos em $300^{\circ} \mathrm{C}$, ou seja do material carbonizado, já revelam a presença de sulfato de sódio, de acordo com o apresentado na Figura 18. Após a queima desse material carbonizado, voltou-se a detectar $\mathrm{Na}_{2} \mathrm{SO}_{4}$ como resíduo de decomposição a temperaturas superiores a $650{ }^{\circ} \mathrm{C}$. Esses resíduos mostram picos entre 1100-1200 $\mathrm{cm}^{-1}$ da ligação $\mathrm{S}=0$, e $600-700 \mathrm{~cm}^{-1}$ do sódio $(\mathrm{Na})$. 
No entanto, como as amostras apresentavam outros picos que não puderam ser caracterizados por IR, julgou-se necessário a caracterização dos mesmos por difração de raios X, Figura 19 e 20. 


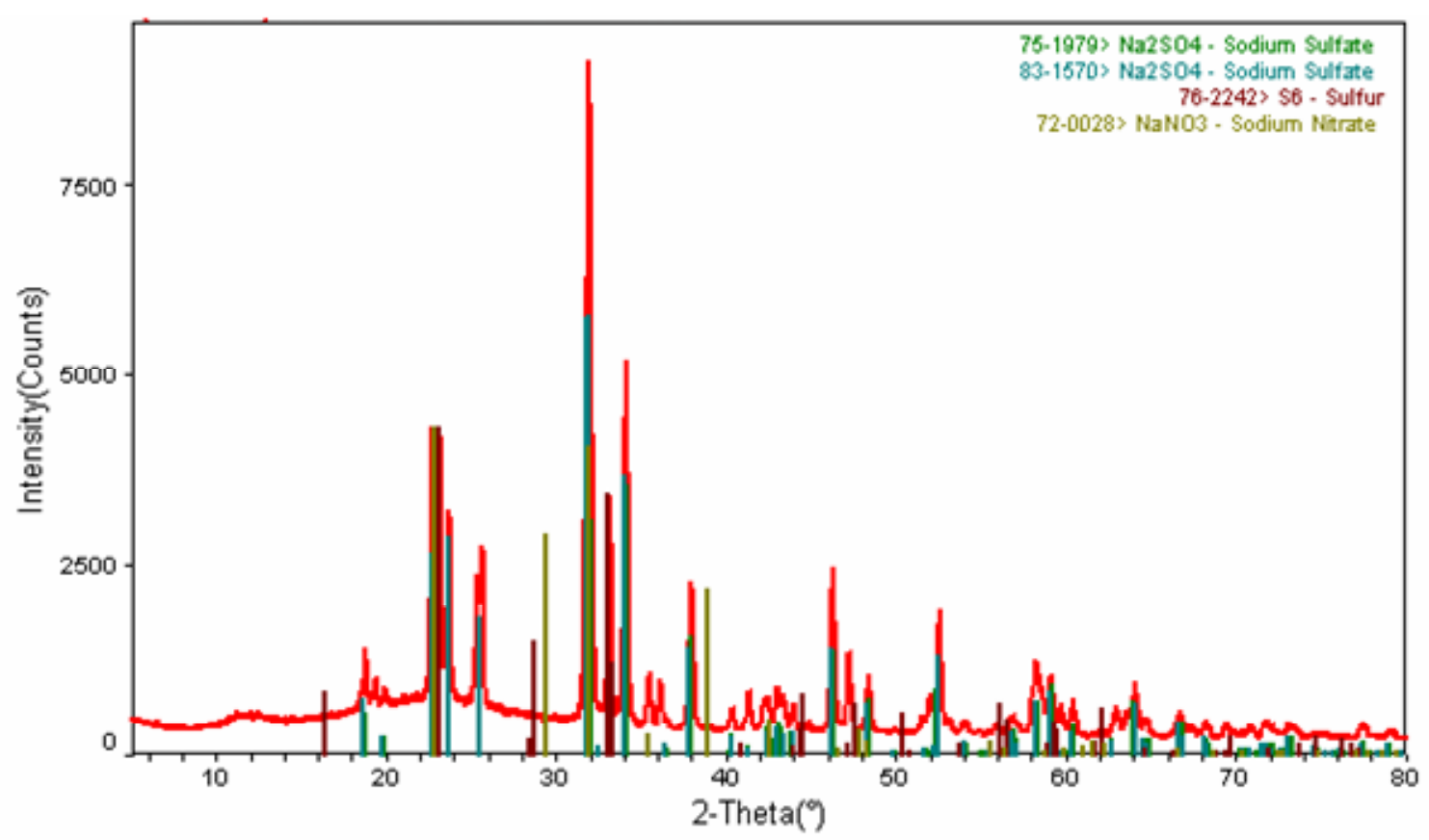

Figura 19. Difratograma de raios $X$ do resíduo de ciclamato de sódio comercial a $330 \stackrel{\circ}{ } \mathrm{C}$.

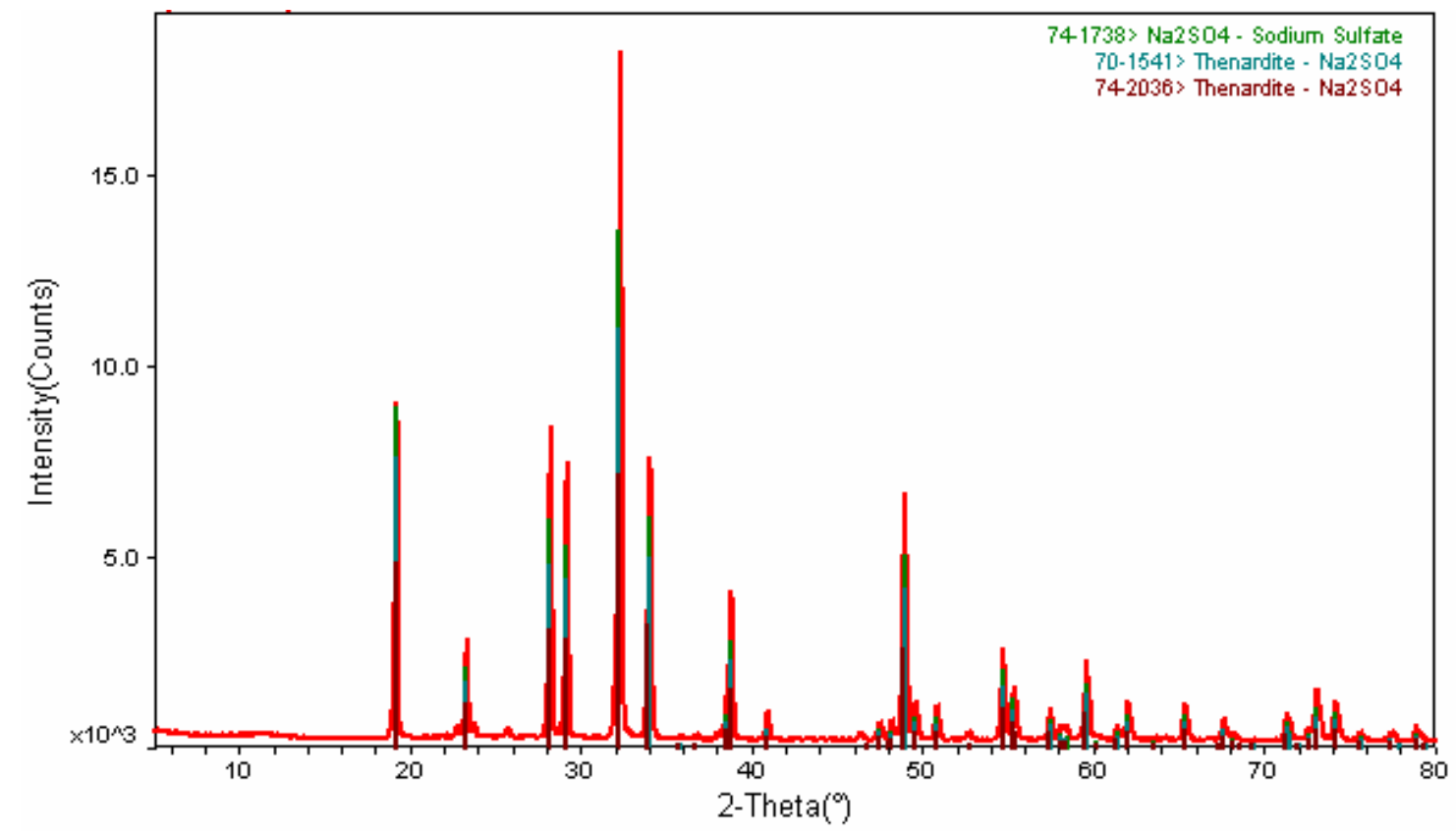

Figura 20. Difratograma de raios $X$ do resíduo de ciclamato de sódio comercial a $660^{\circ} \mathrm{C}$. 
Os difratogramas de raios $\mathrm{X}$ apresentados nas Figuras 19 e 20 confirmam a formação de $\mathrm{Na}_{2} \mathrm{SO}_{4}$ nestas temperaturas como produtos de decomposição térmica do ciclamato de sódio comercial. Como os espectros do ciclamato de sódio comercial e recristalizado são muito parecidos, julgou-se necessário apenas a caracterização por XRD de apenas um deles. 


\subsubsection{Esteviosídeo}

Nas Figuras 21 a e b estão as curvas TG/DTG e TG/DTA obtidas do esteviosídeo. Na Tabela 6, são apresentados os intervalos de temperatura, atribuição dos eventos observados e perdas de massa envolvidas na decomposição. 

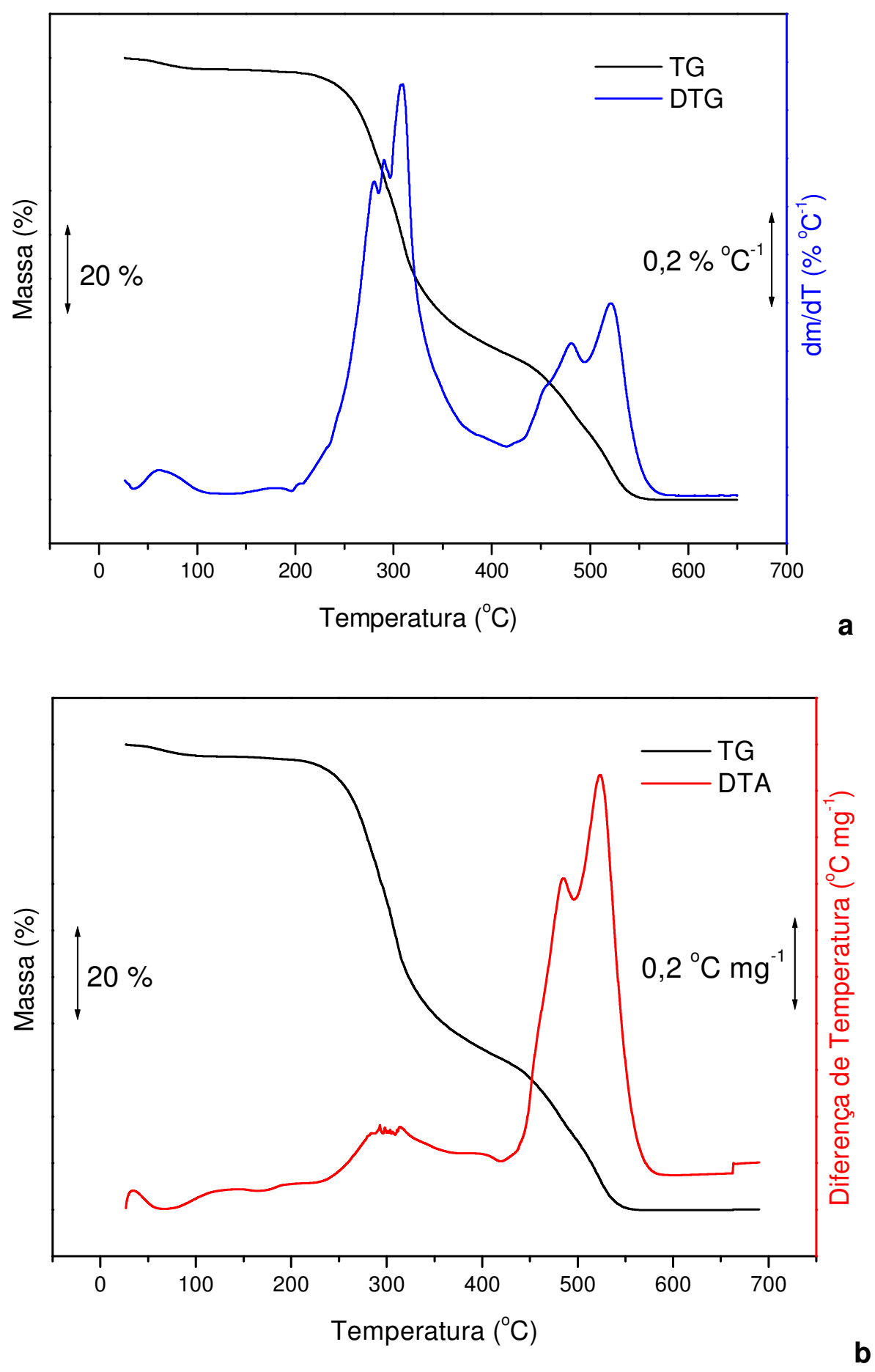

Figura 21. Curvas TG/DTG (a), TG/DTA (b) do esteviosídeo, obtidas sob atmosfera de ar. Vazão de $100 \mathrm{~mL} \mathrm{~min}^{-1}$, massa de amostra de $4 \mathrm{mg}$, razão de aquecimento de 10 o $\mathrm{C} \mathrm{min}^{-1}$ e suporte de amostra de alumina. 
Tabela 6. Atribuições de eventos térmicos, intervalos de temperatura e perdas de massa observados nas curvas TG/DTG do edulcorante esteviosídeo sob atmosfera de ar

\begin{tabular}{|c|c|c|c|c|}
\hline \multirow[t]{2}{*}{ Processo } & \multirow{2}{*}{$\begin{array}{c}\text { Intervalo } \\
\text { temperatura }\left({ }^{\circ} \mathrm{C}\right)\end{array}$} & \multicolumn{2}{|c|}{$\begin{array}{l}\text { Perda de massa ou } \\
\text { resíduo (\%) }\end{array}$} & \multirow[t]{2}{*}{ Picos DTA $\left({ }^{\circ} \mathrm{C}\right)$} \\
\hline & & Experimental & (Calculado) & \\
\hline Desidratação & $26,8-124,4$ & 2,58 & $(6,12)$ & 34,2 \\
\hline $\mathrm{Dec}^{\mathrm{a}} \rightarrow \mathrm{MC}^{\mathrm{b}}$ & $124,4-415,8$ & 64,5 & ------ & $293,7-315,4$ \\
\hline Queima do $\mathrm{MC}^{\mathrm{b}}$ & $415,8-612,7$ & 33,0 & ----- & 483,7 \\
\hline Resíduo & 612,7 & 0,0 & $(0,0)$ & 523,7 \\
\hline
\end{tabular}

Em que: $\mathbf{a}=$ decomposição (Dec); $\mathbf{b}=$ material carbonizado $(\mathrm{MC})$

Como pode ser visto na Figura 21, após a desidratação, a decomposição ocorre em duas etapas. As curvas TG sugerem eventos complexos de decomposição com sobreposições, que provavelmente ocorrem devido à presença de outras substâncias edulcorantes como o rebaudiosídeo A e outras denominadas "edulcorantes totais" não divulgados pelo fabricante. De acordo com Kroyer ${ }^{42}$, o esteviosídeo mostrou-se estável até $120{ }^{\circ} \mathrm{C}$ aproximadamente. Este estudo foi realizado com HPLC (high-performance liquid chromatography) e TLC (thin-layer chromatography). Entretanto, as curvas TG sugerem estabilidade até $175^{\circ} \mathrm{C}$, sob as condições de trabalho usadas neste estudo.

As curvas DTA mostram a desidratação com pico endotérmico, e os eventos a decomposição e queima de matéria orgânica, na forma de eventos exotérmicos.

Em uma tentativa de interpretação dos resíduos obtidos a temperatura ambiente e após aquecimento a 120, 300 e $370{ }^{\circ} \mathrm{C}$, foi necessário a caracterização por IR.

Os espectros são apresentados na Figura 22 e mostram o perfil estável até $120^{\circ} \mathrm{C}$. Acima de $300^{\circ} \mathrm{C}$, nota-se alteração na forma do espectro, que foi atribuída a decomposição da amostra nesta temperatura. 


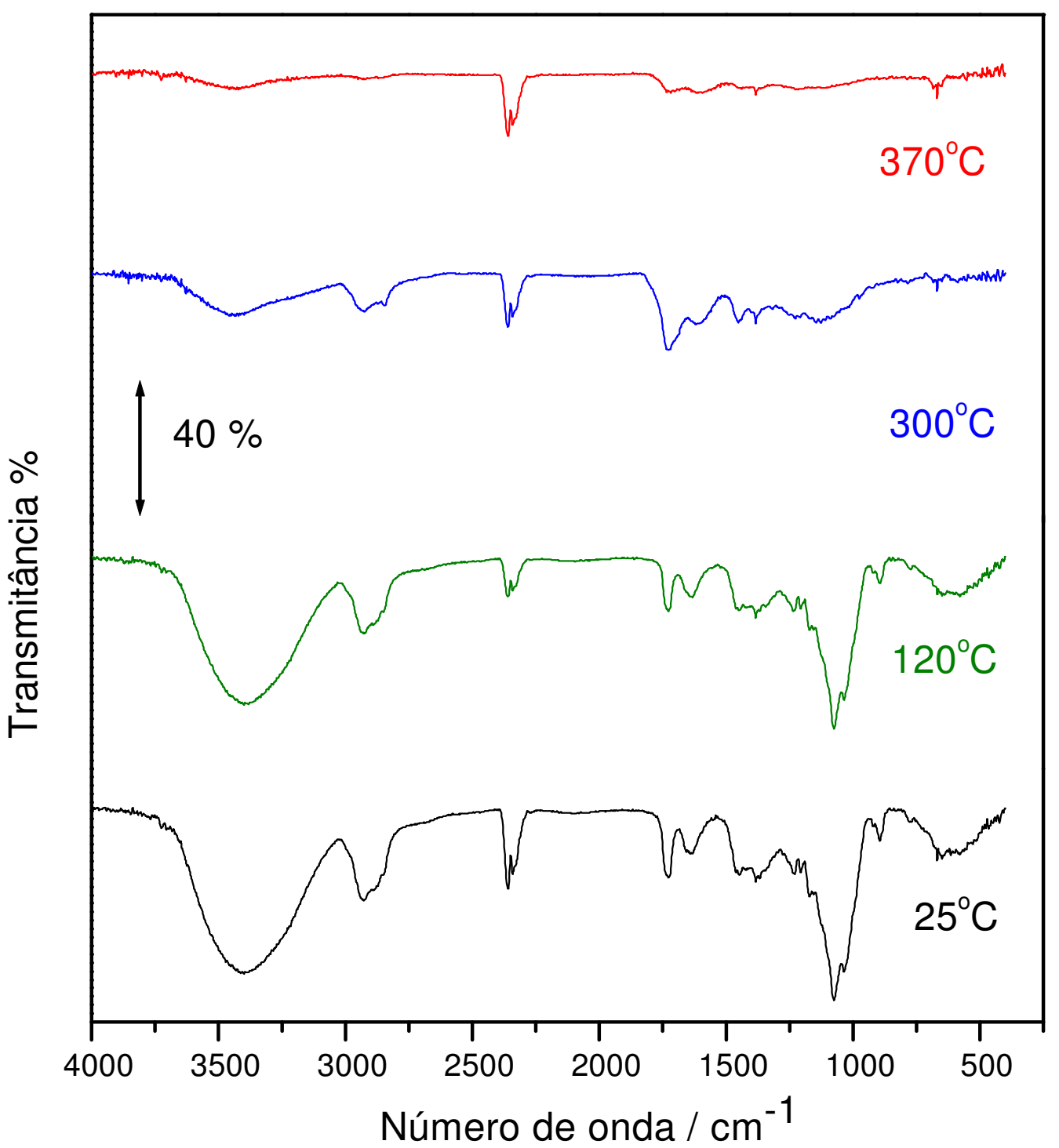

Figura 22. Espectros de absorção na região do infravermelho dos resíduos de esteviosídeo em diferentes temperaturas.

Em $300{ }^{\circ} \mathrm{C}$, já não é tão evidente a banda de absorção entre 3100 a 3700 $\mathrm{cm}^{-1}$, indicando desidratação da amostra, tão pouco a banda entre 1000 a $1200 \mathrm{~cm}^{-1}$ de ligação $\mathrm{O}-\mathrm{H}$ de álcool primário. Após $370{ }^{\circ} \mathrm{C}$ aproximadamente, o espectro sugere material decomposto.

Apesar de obtidos os espectros de IR, a elucidação do mecanismo de decomposição térmica do esteviosídeo foi prejudicada em razão da presença de 
grande quantidade de material carbonizado nas amostras. A caracterização por difração de raios X, também não foi possível, pois os intermediários eram amorfos.

Ao final do experimento a perda de massa é total e não há resíduo no cadinho, pois trata-se de amostra de material orgânico. 


\subsubsection{Sacarina}

Nas Figuras 23 a e b estão as curvas TG/DTG e TG/DTA obtidas da sacarina (sacarina H) e logo abaixo na Tabela 7, são apresentados os intervalos de temperatura, atribuição dos eventos observados e perdas de massa envolvidas na decomposição. 

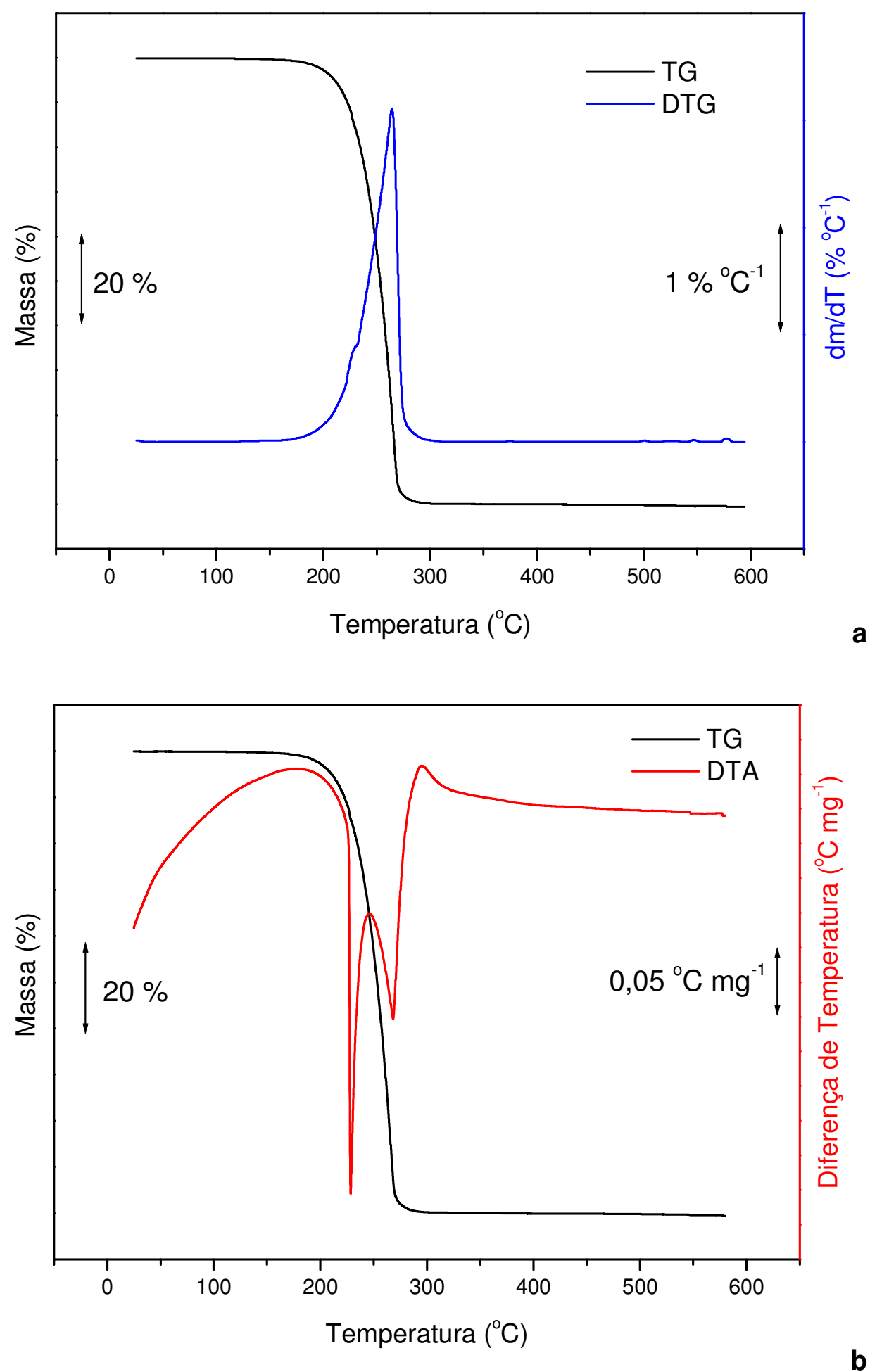

Figura 23. Curvas TG e DTG, TG e DTA da sacarina $H$, obtidas sob atmosfera de ar. Vazão de $100 \mathrm{~mL} \mathrm{~min}{ }^{-1}$, massa de amostra de $4 \mathrm{mg}$, razão de aquecimento de $10 \stackrel{\circ}{ }{ }^{\circ}$ $\min ^{-1}$ e suporte de amostra de alumina. 
Tabela 7. Atribuições de eventos térmicos, intervalos de temperatura e perdas de massa observados nas curvas TG/DTG do edulcorante sacarina (sacarina $H$ ) sob atmosfera de ar

\begin{tabular}{|c|c|c|c|c|}
\hline \multirow[t]{2}{*}{ Processo } & \multirow{2}{*}{$\begin{array}{c}\text { Intervalo } \\
\text { temperatura }\left({ }^{\circ} \mathrm{C}\right)\end{array}$} & \multicolumn{2}{|c|}{$\begin{array}{l}\text { Perda de massa ou } \\
\text { resíduo (\%) }\end{array}$} & \multirow[t]{2}{*}{$\operatorname{Picos} \mathrm{DTA}\left({ }^{\circ} \mathrm{C}\right)$} \\
\hline & & Experimental & (Calculado) & \\
\hline Fusão & $24,1-232,0$ & 18,4 & ------ & 227,9 \\
\hline Volatilização & $232,0-530,0$ & 82,2 & ------ & 268,7 \\
\hline Resíduo & 530,0 & $-0,6$ & $(0,0)$ & 297,3 \\
\hline
\end{tabular}

Em que: $\mathbf{a}=$ decomposição (Dec); $\mathbf{b}$ = material carbonizado (MC)

Segundo Bernal ${ }^{21}$, o primeiro evento foi atribuído à fusão, acompanhada por volatilização da amostra, representados pelos picos endotérmicos na curva DTA da Figura 23 b.

Para confirmar esta proposta, uma amostra de sacarina foi aquecida em um tubo de ensaio de $20 \mathrm{~cm}$ de comprimento.

Durante o aquecimento da amostra, verificou-se a fusão do material, seguida de volatilização com condensação de sacarina, na forma de cristais na parede do tubo de ensaio acima da zona aquecida. Estas observações estão de acordo com o que foi relatado por Bernal et $\mathrm{al}^{21}$.

Com a obtenção desses cristais, foi obtido um espectro na região do IV dos mesmos e então se comparou com o espectro de sacarina H, Figura 24. 


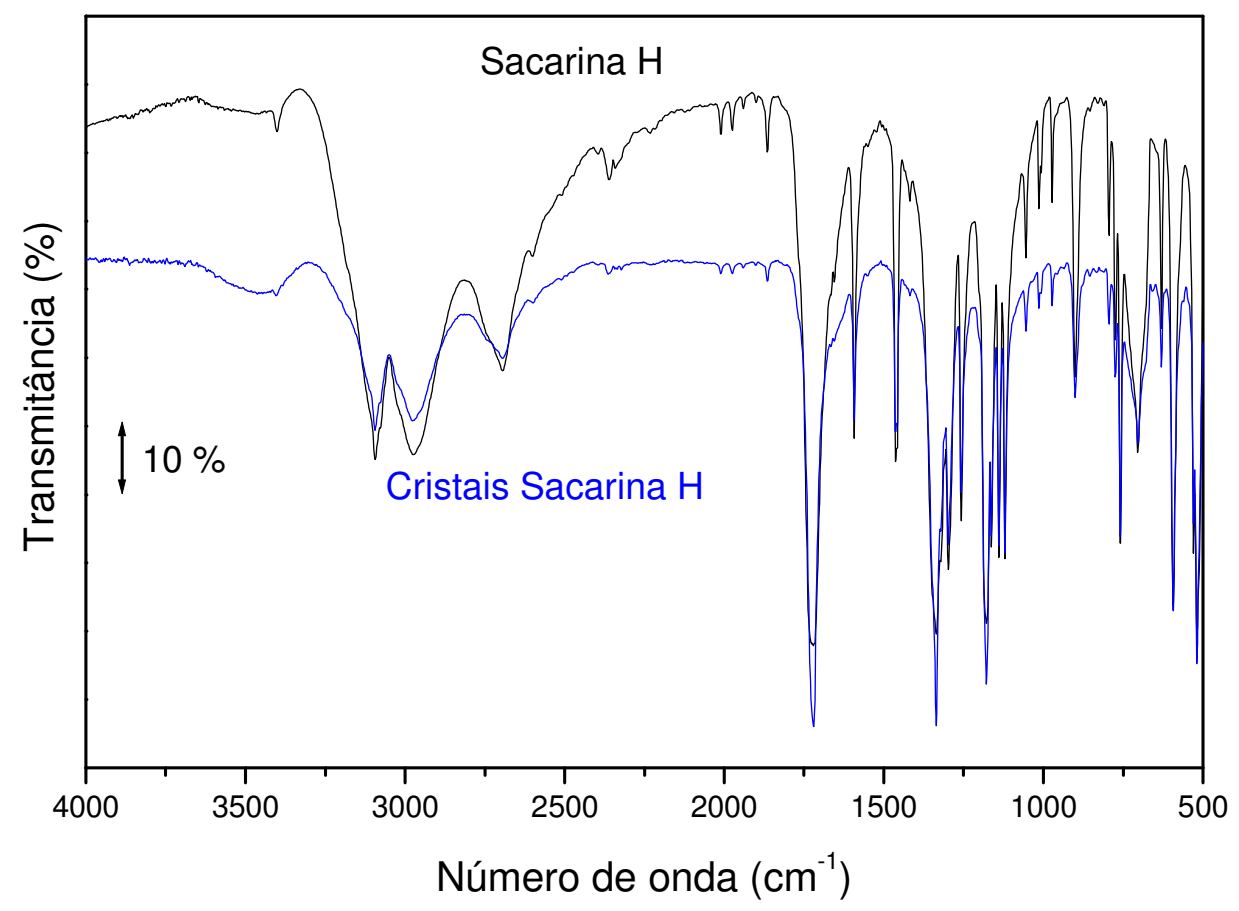

Figura 24. Espectros de absorção na região do infravermelho dos cristais presentes no tubo de ensaio com amostra de sacarina após aquecimento (aproximadamente $\left.230{ }^{\circ} \mathrm{C}\right)$.

A partir da Figura 24, pode-se afirmar que os cristais presentes nas paredes do tubo de ensaio são resultados da volatilização, apresentando picos de absorbância na mesma região de número de onda que a sacarina $\mathrm{H}$. 


\subsubsection{Sacarina Sódica}

Nas Figuras 25 a e b, 26 a e b estão as curvas TG/DTG e TG/DTA obtidas da sacarina sódica comercial e recristalizada, respectivamente. Abaixo na Tabela 8, são apresentados os intervalos de temperatura, atribuição dos eventos observados e perdas de massa envolvidas na decomposição. 


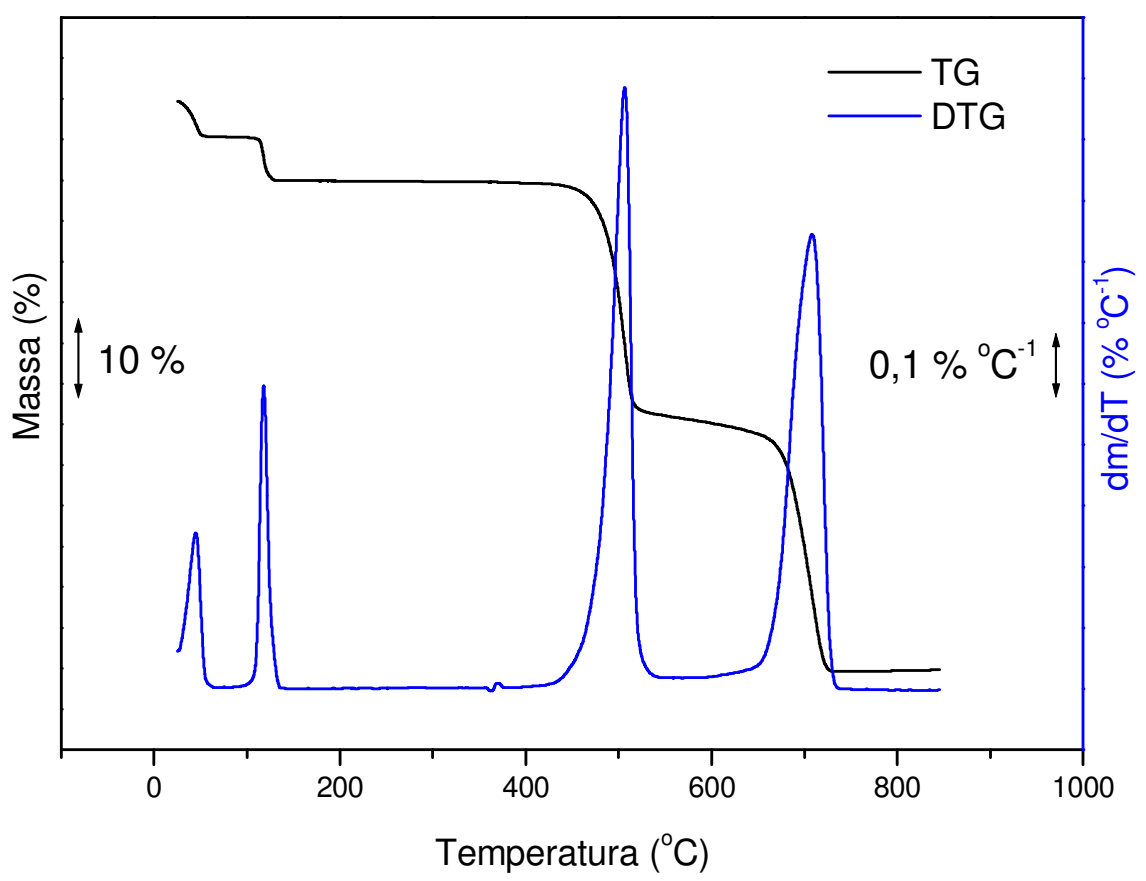

a

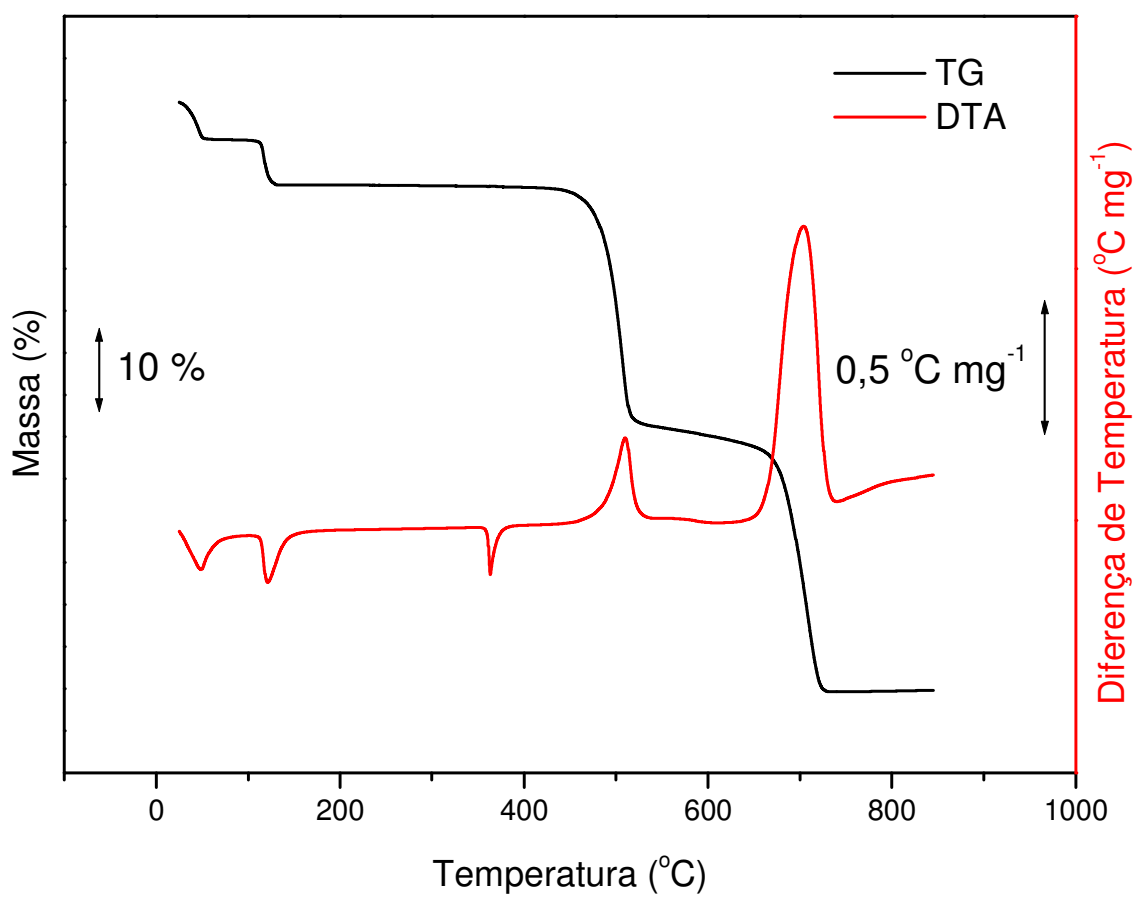

b

Figura 25. Curvas TG e DTG (a), TG e DTA (b) da sacarina sódica comercial obtida sob atmosfera de ar. Vazão de $100 \mathrm{~mL} \mathrm{~min}^{-1}$, massa de amostra de $4 \mathrm{mg}$, razão de aquecimento de $10^{\circ} \mathrm{C} \mathrm{min}^{-1}$ e suporte de amostra de alumina. 


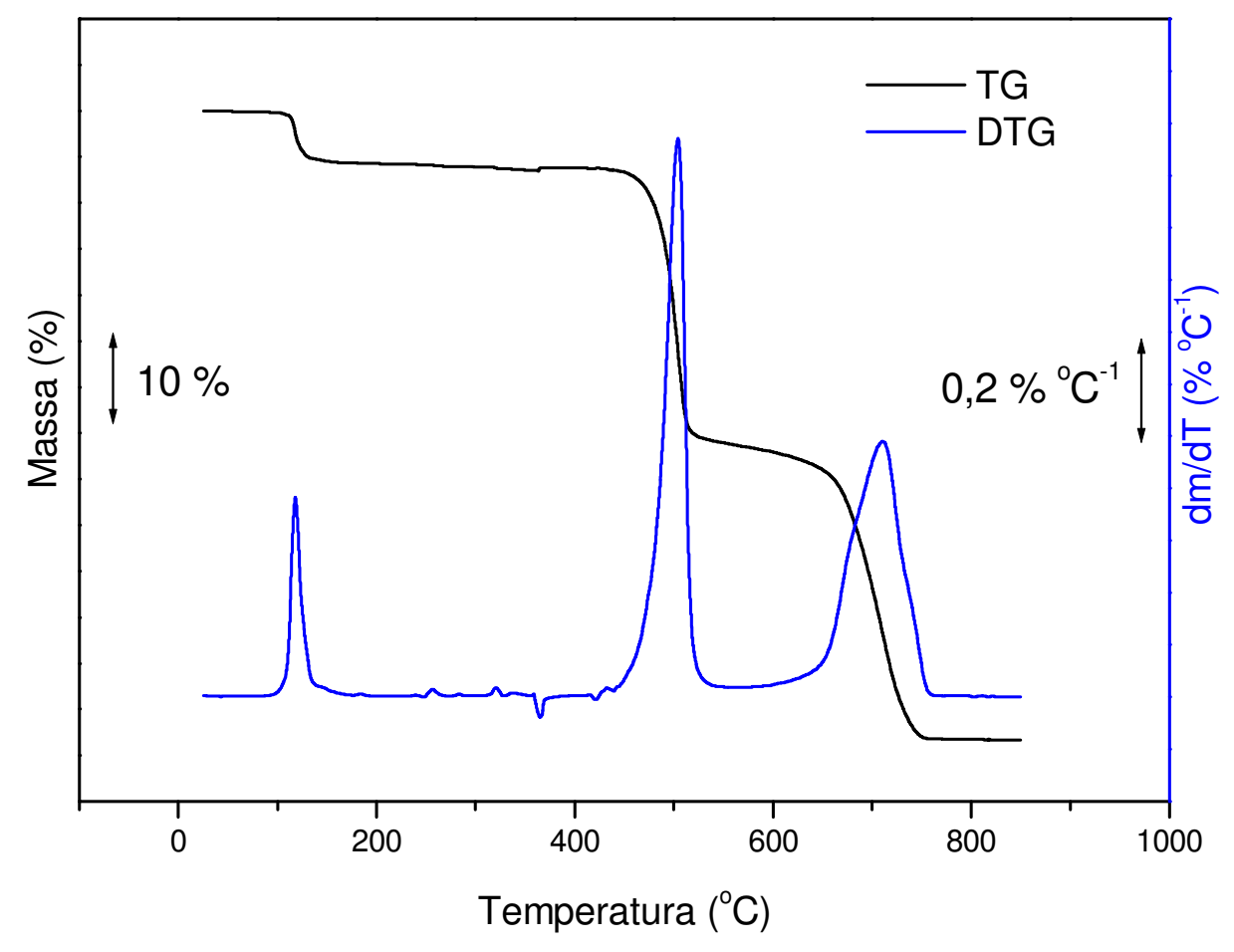

a

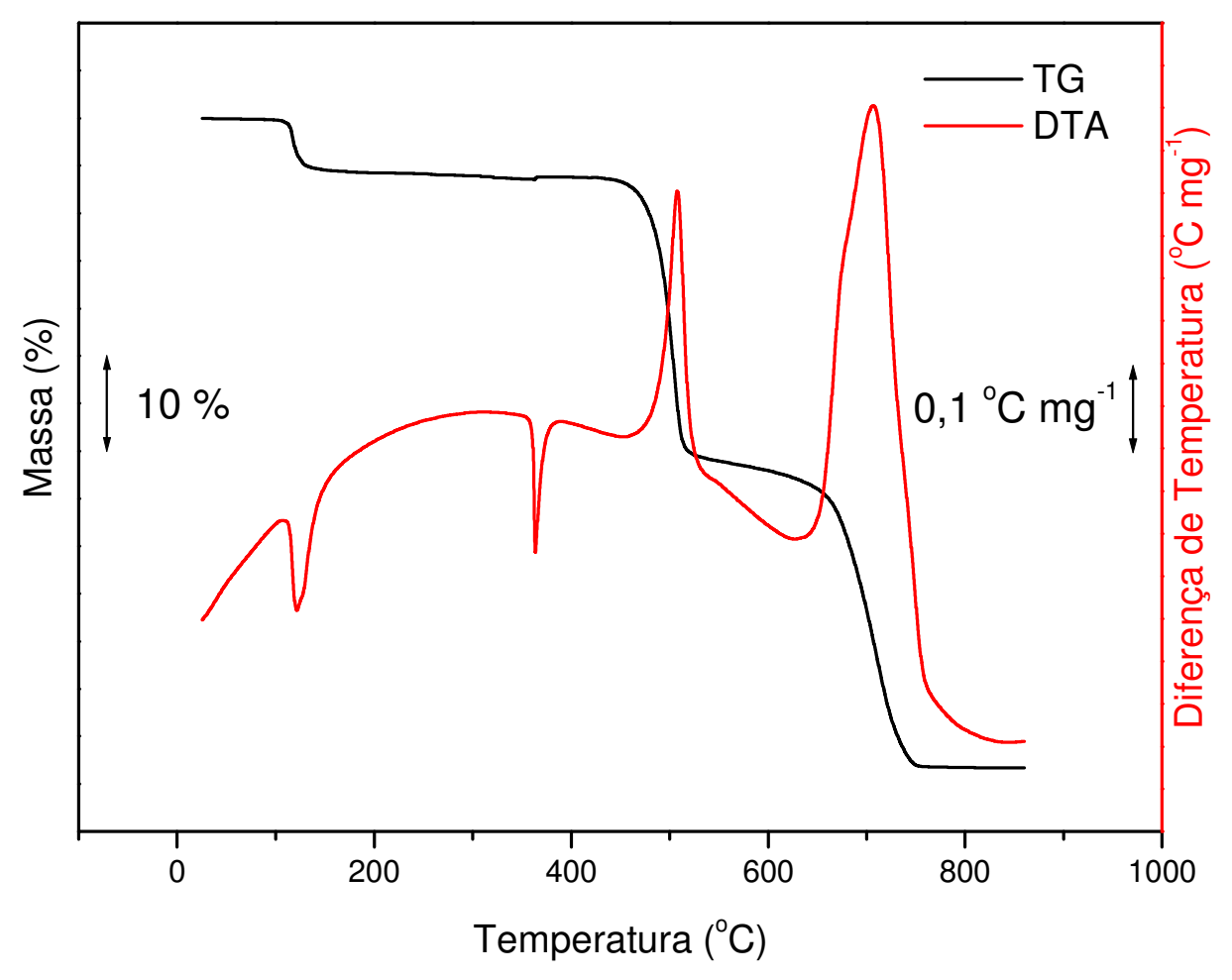

b

Figura 26. Curvas TG e DTG (a), TG e DTA (b) da sacarina sódica recristalizada, obtidas sob atmosfera de ar. Vazão de $100 \mathrm{~mL} \mathrm{~min}^{-1}$, massa de amostra de $4 \mathrm{mg}$, razão de aquecimento de $10{ }^{\circ} \mathrm{C} \min ^{-1}$ e suporte de amostra de alumina. 
Tabela 8. Atribuições de eventos térmicos, intervalos de temperatura e perdas de massa observados nas curvas TG/DTG dos edulcorantes sacarina sódica comercial e recristalizado sob atmosfera de ar

\begin{tabular}{|c|c|c|c|c|c|}
\hline \multirow[t]{2}{*}{ Edulcorante } & \multirow[t]{2}{*}{ Processo } & \multirow{2}{*}{$\begin{array}{c}\text { Intervalo } \\
\text { temperatura }\left({ }^{\circ} \mathrm{C}\right)\end{array}$} & \multicolumn{2}{|c|}{$\begin{array}{c}\text { Perda de massa ou } \\
\text { resíduo (\%) }\end{array}$} & \multirow{2}{*}{$\begin{array}{c}\text { Picos DTA } \\
\left({ }^{\circ} \mathrm{C}\right)\end{array}$} \\
\hline & & & Experimental & (Calculado) & \\
\hline \multirow{6}{*}{ Comercial } & Desidratação & $21,8-69,3$ & 4,6 & $(4,1)$ & 47,5 \\
\hline & Desidratação & $69,3-155,0$ & 5,4 & $(5,6)$ & 122,5 \\
\hline & $\mathrm{Dec}^{\mathrm{a}} \rightarrow \mathrm{MC}^{\mathrm{b}}$ & $155,0-571,3$ & 29,2 & ------ & 362,9 \\
\hline & Queima do $\mathrm{MC}^{\mathrm{b}}$ & & & & \\
\hline & $\left(\mathrm{Na}_{2} \mathrm{SO}_{4}\right)$ & $571,3-845,0$ & 30,9 & ----- & 508,6 \\
\hline & Resíduo $\left(\mathrm{Na}_{2} \mathrm{SO}_{4}\right)$ & 845,0 & 29,8 & 30,9 & 703,8 \\
\hline \multirow{5}{*}{ Recristalizado } & Desidratação & $21,3-195,4$ & 5,7 & $(5,6)$ & 122,5 \\
\hline & $\mathrm{Dec}^{\mathrm{a}} \rightarrow \mathrm{MC}^{\mathrm{b}}$ & $195,4-565,0$ & 30,6 & ------ & 364,3 \\
\hline & Queima do $\mathrm{MC}^{\mathrm{b}}$ & & & & \\
\hline & $\left(\mathrm{Na}_{2} \mathrm{SO}_{4}\right)$ & $565,0-893,4$ & 32,2 & ------ & 508,6 \\
\hline & Resíduo $\left(\mathrm{Na}_{2} \mathrm{SO}_{4}\right)$ & 893,4 & 31,4 & $(32,4)$ & 706,6 \\
\hline
\end{tabular}

Em que: $\mathbf{a}=$ decomposição (Dec); $\mathbf{b}=\overline{\text { material carbonizado }(\mathrm{MC})}$

No caso da sacarina sódica comercial, foram observados dois eventos de desidratação de acordo com os resultados descritos na Tabela 8. As perdas de massa sugerem que o primeiro processo de desidratação ocorre com liberação de 0,62 $\cdot \mathrm{H}_{2} \mathrm{O}$. A quantidade não estequiométrica foi atribuída à volatilidade desta água e sua possível perda durante o manuseio da amostra, já que esta tem origem comercial.

Já segunda perda se refere a $0,75 \mathrm{H}_{2} \mathrm{O}$, em concordância com o que foi descrito por Naumov et $\mathrm{al}^{45}$. 
A sacarina sódica, após recristalização, apresentou apenas a perda de 0,75 . $\mathrm{H}_{2} \mathrm{O}$. A ausência do primeiro evento de desidratação, foi atribuída à perda de água durante a secagem do composto a vácuo.

Na seqüência, as curvas são bastante similares nos dois casos, mostrando fusão em $380{ }^{\circ} \mathrm{C}$, melhor evidenciada na curva DTA, e decomposição em duas etapas, sendo a segunda provavelmente, referente à queima de material carbonizado. Esse material gerou um resíduo de 29,81 para a sacarina sódica comercial e $31,45 \%$ para a recristalizada. Os resíduos finais obtidos estão de acordo com os calculados que são de 30,90 e 32,48 \%, respectivamente para sulfato de sódio.

Espectros de infravermelho foram obtidos em diferentes temperaturas, nas quais os intermediários se mostraram estáveis a 25, 100, 200, 520 e $750{ }^{\circ} \mathrm{C}$. Os espectros dos resíduos nestas temperaturas são apresentados nas Figuras 27 e 28 para a amostra comercial e para a recristalizada, respectivamente. 


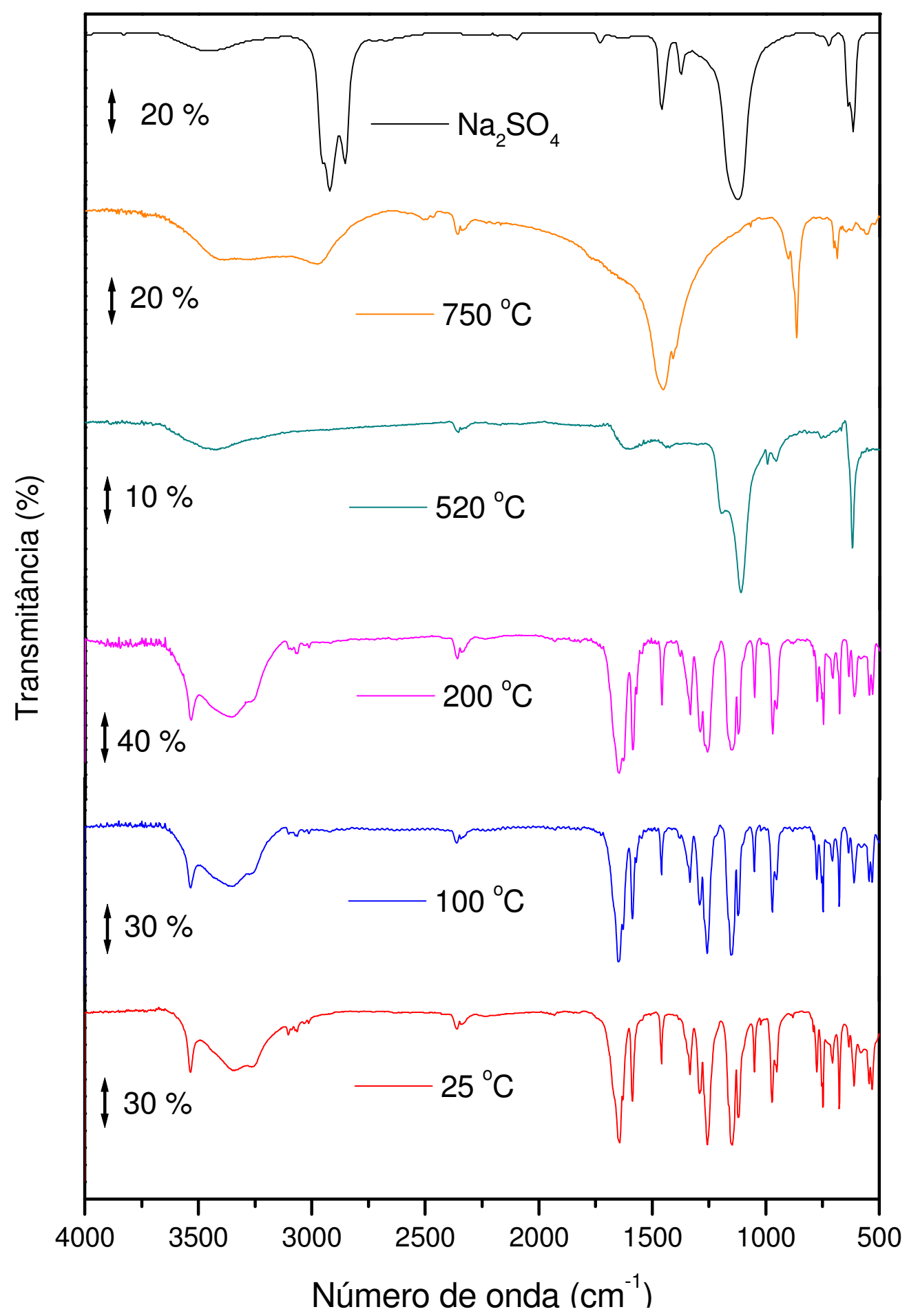

Figura 27. Espectros de absorção na região do infravermelho dos resíduos de sacarina sódica comercial em diferentes temperaturas e de sulfato de sódio $\left(\mathrm{Na}_{2} \mathrm{SO}_{4}\right.$ 20444-7 Aldrich FT-IR) ${ }^{49}$. 


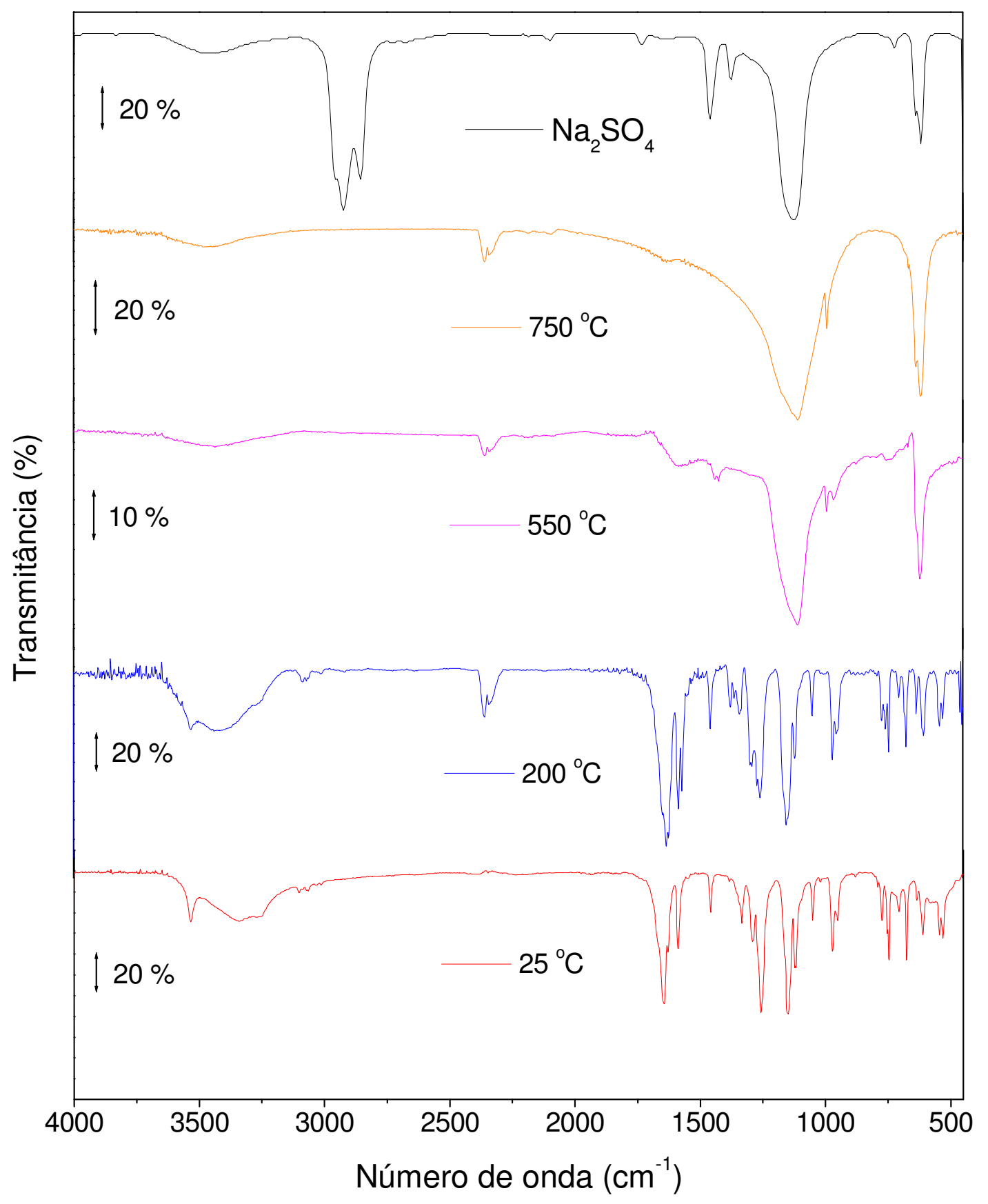

Figura 28. Espectros de absorção na região do infravermelho dos resíduos de sacarina sódica recristalizada em diferentes temperaturas e de sulfato de sódio $\left(\mathrm{Na}_{2} \mathrm{SO}_{4}\right.$ 20444-7 Aldrich FT-IR) ${ }^{49}$. 
Nota-se que com a evolução espectral, após $200{ }^{\circ} \mathrm{C}$ a amostra se decompõe formando $\mathrm{Na}_{2} \mathrm{SO}_{4}$ como resíduo já em $550{ }^{\circ} \mathrm{C}$, o que se mantém até o final do experimento a $750{ }^{\circ} \mathrm{C}$ (ver espectro de sulfato de sódio nas Figuras 27 e 28).

Para confirmação dos mesmos e considerando picos diferentes do padrão nos espectros de IR, foi tomado a difração de raios $X$ para o resíduo de sacarina comercial a $750^{\circ} \mathrm{C}$, como Figura 29.

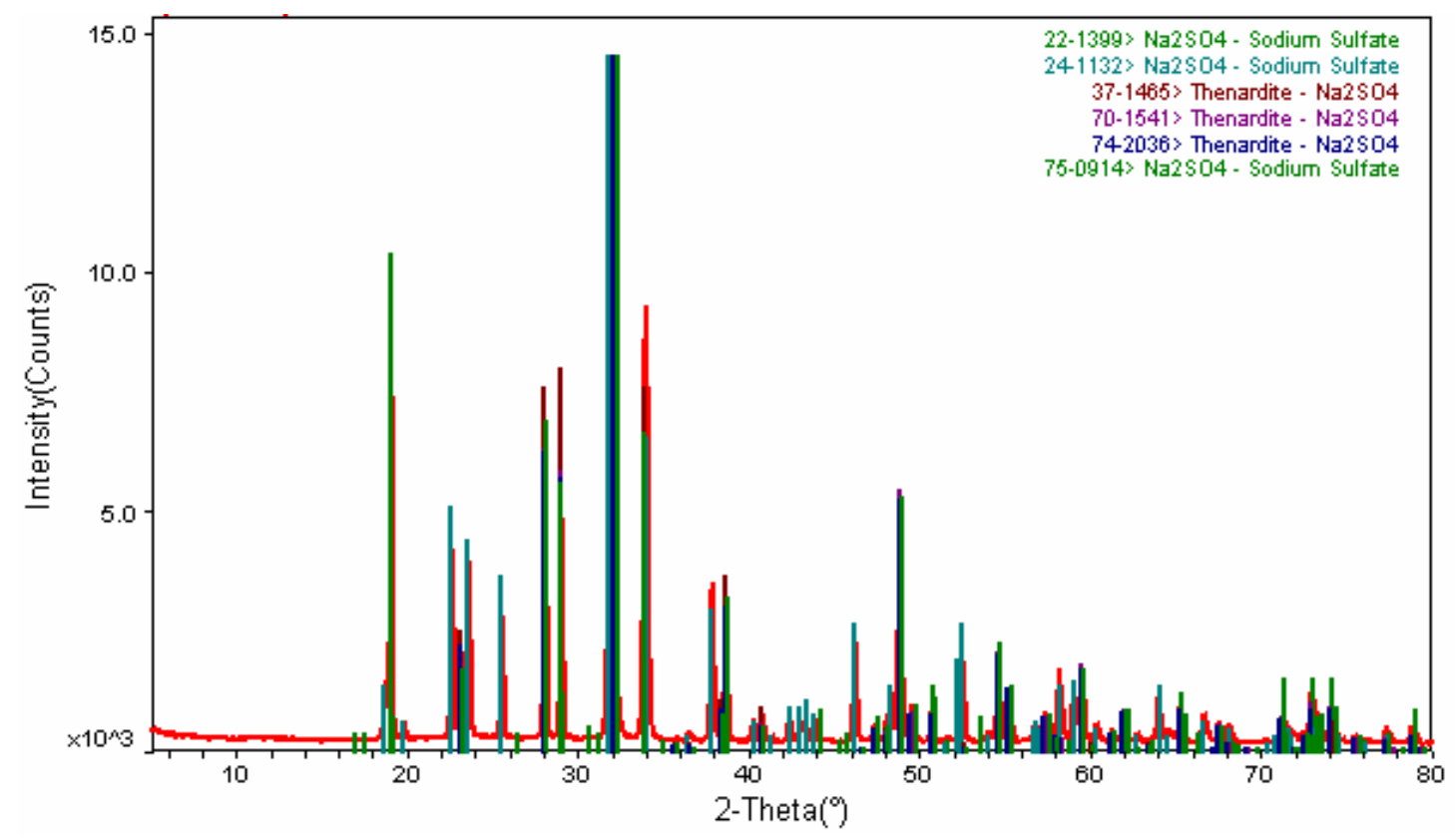

Figura 29. Difratograma de raios $X$ do resíduo de sacarina sódica comercial a $750 \stackrel{\circ}{\circ}$.

O difratograma mostrou picos de sulfato de sódio para o resíduo obtido, mostrando-se de acordo com os resultados obtidos por IR. 


\subsection{Calorimetria Exploratória Diferencial (DSC)}

As curvas DSC foram obtidas em intervalo de temperatura de $-70 \stackrel{\circ}{\circ} \mathrm{C}$ a uma temperatura final escolhida de acordo com a decomposição de cada amostra. As curvas são apresentadas na Figura 30.

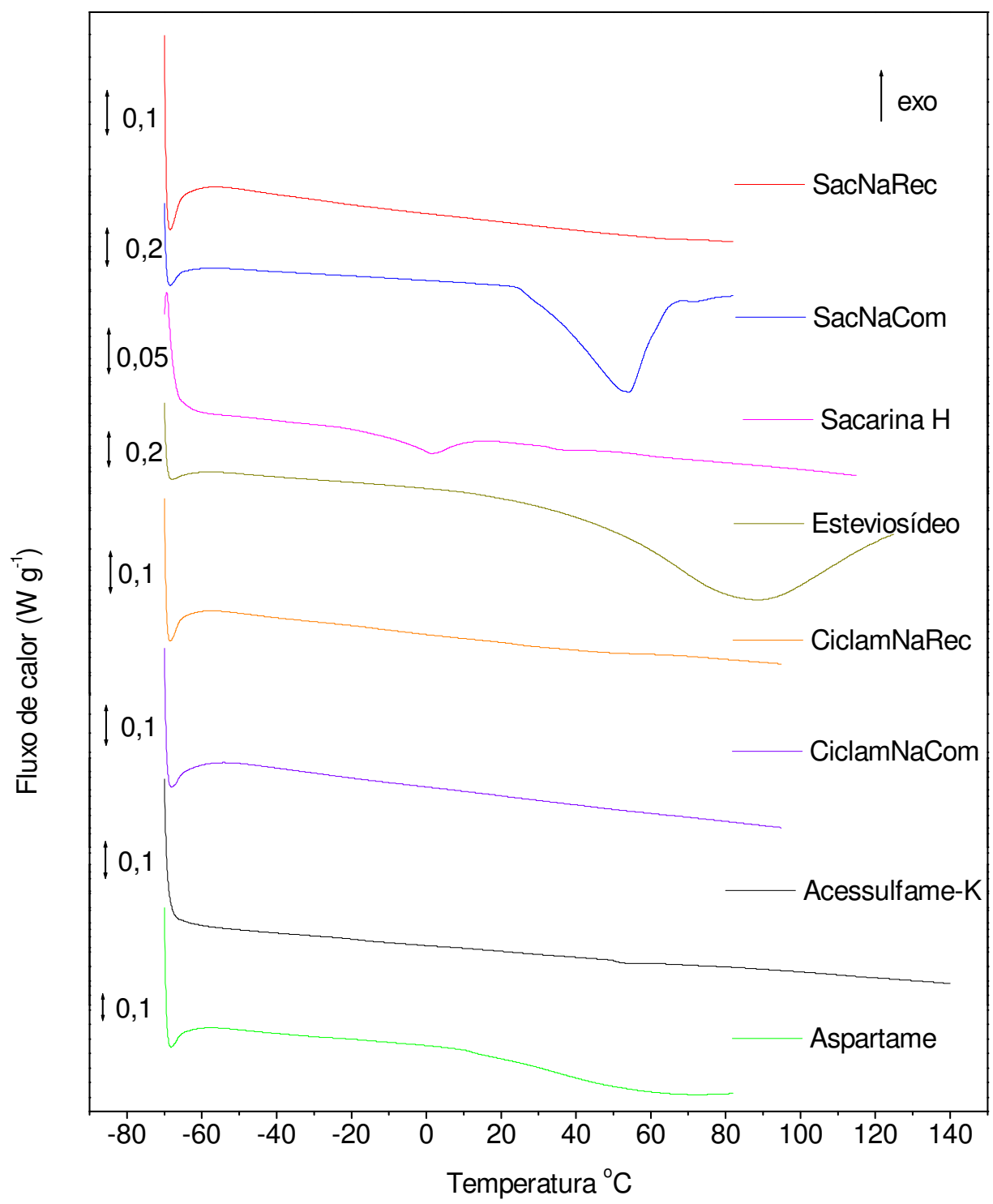

Figura 30. Curvas DSC obtidas sob atmosfera dinâmica de $\mathrm{N}_{2}$ com vazão de $100 \mathrm{~mL} \mathrm{~min}{ }^{-1}$ para os edulcorantes acessulfame-K, aspartame, ciclamato de sódio comercial e recristalizado, esteviosídeo, sacarina, sacarina sódica comercial e recristalizada. Massa de amostra de $3 \mathrm{mg}$, razão de aquecimento de $10 \stackrel{\circ}{\circ} \mathrm{C} \mathrm{min}^{-1}$, inicial -70 a $130 \stackrel{\circ}{ } \mathrm{C}$, em suporte de amostra de alumínio tampado, com furo central. 
O objetivo desses estudos foi o de verificar a presença de picos de fusão ou transições estruturais que precedessem as decomposições, em temperaturas subambiente.

A sacarina $\mathrm{H}$ possui um pequeno pico endotérmico próximo de zero grau. Provavelmente, este evento deve-se à água de adsorção presente na amostra, a qual é facilmente eliminada.

A sacarina sódica comercial, assim como o esteviosídeo e o aspartame apresentam picos endotérmicos decorrentes da desidratação em concordância com os resultados TG. Para o aspartame e o esteviosídeo este processo tem início em torno de $25{ }^{\circ} \mathrm{C}$, e para a sacarina sódica comercial em torno de $30^{\circ} \mathrm{C}$. Como no caso da sacarina sódica recristalizada, acredita-se que a temperatura ambiente, durante o processo de recristalização e secagem causou a perda da água, a qual não é observada na curva DSC. 


\subsection{Cinética de decomposição térmica}

Os parâmetros cinéticos de decomposição térmica dos edulcorantes aspartame e sacarina $\mathrm{H}$, foram obtidos aplicando-se o método dinâmico de FlynnWall e Ozawa, utilizando-se curvas TG em razões de aquecimento $(\beta)$ de 2,5; 5; 7,5 e $10 \stackrel{\circ}{\circ} \mathrm{min}^{-1}$ sob atmosfera de $\mathrm{N}_{2}\left(100 \mathrm{~mL} \mathrm{~min}^{-1}\right)$, nos níveis conversionais $(\alpha)$ de 5; $10 ; 15 ; 20 ; 25 ; 30 ; 35 ; 40 ; 45 ; 50 \%$. Abaixo, estão as curvas TG do aspartame e sacarina $\mathrm{H}$ sob as diferentes razões de aquecimento, que foram utilizadas para o estudo cinético.

Para um estudo de parâmetros cinéticos de decomposição térmica, é preciso escolher eventos térmicos bem definidos e regiões da curva TG, nas quais não haja sobreposição de eventos.

Por esse motivo não foi possível realizar estes cálculos para todos os edulcorantes investigados neste trabalho.

Escolheu-se a aspartame, que apresenta processo de decomposição entre $230-400{ }^{\circ} \mathrm{C}$, após desidratação e a sacarina, que volatiliza após fusão em uma única etapa. Os demais edulcorantes apresentam eventos simultâneos, que impedem os estudos cinéticos. 


\subsubsection{Aspartame}

As curvas TG obtidas para o aspartame entre $25-450{ }^{\circ} \mathrm{C}$ são apresentadas na Figura 31 e foram usadas para cálculo dos parâmetros de energia de ativação $\left(E_{a}\right)$ e fator pré-exponencial de Arrhenius para a decomposição deste edulcorante após a desidratação.

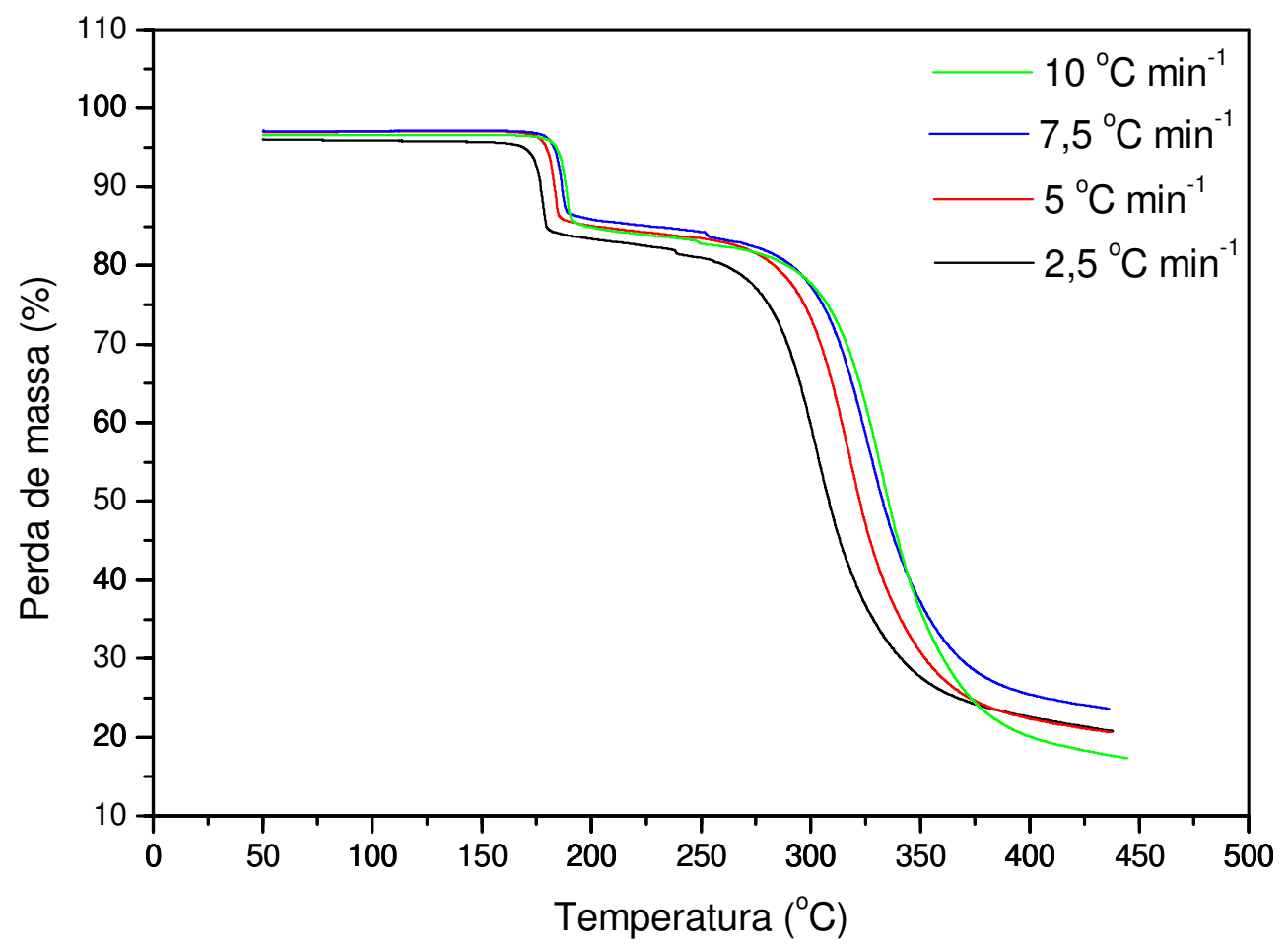

Figura 31. Curvas TG do aspartame obtidas a várias razões de aquecimento, sob atmosfera de $\mathrm{N}_{2}$, em suporte de alumina.

As curvas de $\log \beta$ vs $1 / \mathrm{T}$ para o aspartame são apresentadas na Figura 32, mostram paralelismo e permitem obter os resultados apresentados na Tabela 9, usando-se o programa computacional da TA Instruments. 


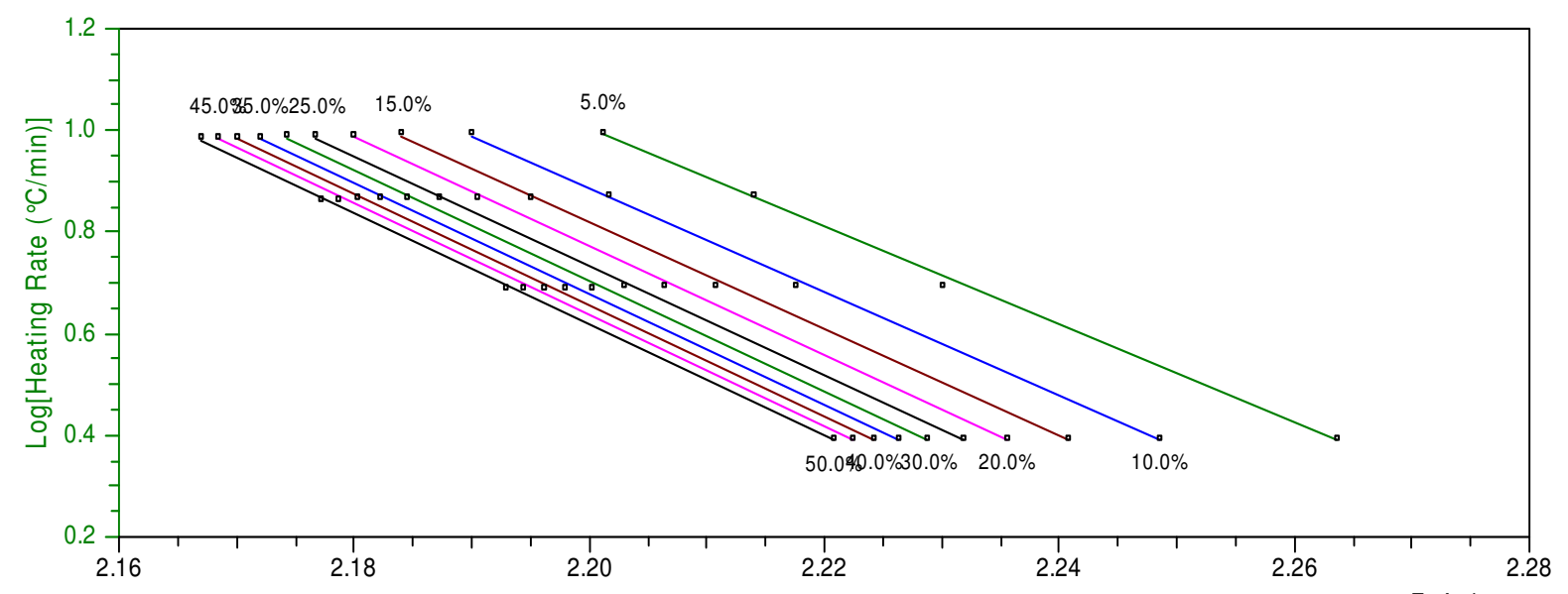

Figura 32. Logaritmo da razão de aquecimento em função do inverso da temperatura para os níveis de decomposição térmica fixados para o aspartame.

Tabela 9. Parâmetros cinéticos de decomposição térmica do aspartame obtido para cada nível de conversão ( $T_{1 / 2} 60$ min - temperatura para meia vida de 60 minutos)

\begin{tabular}{|c|c|c|c|c|}
\hline Composto & $\begin{array}{c}\text { Conversão } \\
(\%)\end{array}$ & $\begin{array}{c}\mathrm{E}_{\mathrm{a}} \\
\left(\mathrm{KJ} \mathrm{mol}^{-1}\right)\end{array}$ & $\begin{array}{l}\log A \\
\left(\min ^{-1}\right)\end{array}$ & $\begin{array}{c}\mathrm{T}_{1 / 2} 60 \mathrm{~min} \\
\left({ }^{\circ} \mathrm{C}\right)\end{array}$ \\
\hline \multirow{10}{*}{ Aspartame } & 5,0 & 183,1 & 19,81 & 166,7 \\
\hline & 10,0 & 194,2 & 21,30 & 163,4 \\
\hline & 15,0 & 199,8 & 22,07 & 161,5 \\
\hline & 20,0 & 203,2 & 22,56 & 160,2 \\
\hline & 25,0 & 204,6 & 22,80 & 159,0 \\
\hline & 30,0 & 206,1 & 23,03 & 158,0 \\
\hline & 35,0 & 206,5 & 23,13 & 157,1 \\
\hline & 40,0 & 206,8 & 23,22 & 156,2 \\
\hline & 45,0 & 206,9 & 23,28 & 155,4 \\
\hline & 50,0 & 206,9 & 23,32 & 154,6 \\
\hline
\end{tabular}

Os valores de $E_{a}$ variam com o fator de conversão $(\alpha)$ de $5-30 \%$, mostrando alguma influência da desidratação sobre a decomposição neste intervalo. Acima de $30 \%$ chegou-se a um valor de $E_{a}=206,6 \pm 0,3 \mathrm{KJ} \mathrm{mol}^{-1}(\mathrm{n}=5)$ e 
$\log A=23,2$ mim $^{-1} \pm 0,1$, obtidas para $\alpha=30 ; 35 ; 40 ; 45 ; 50 \%$. Nessas condições, a temperatura de meia vida em 60 minutos foi estimada em $156,3{ }^{\circ} \mathrm{C}$.

A dependência de $E_{a}$ com a é mostrada na Figura 33 e demonstra estas observações.

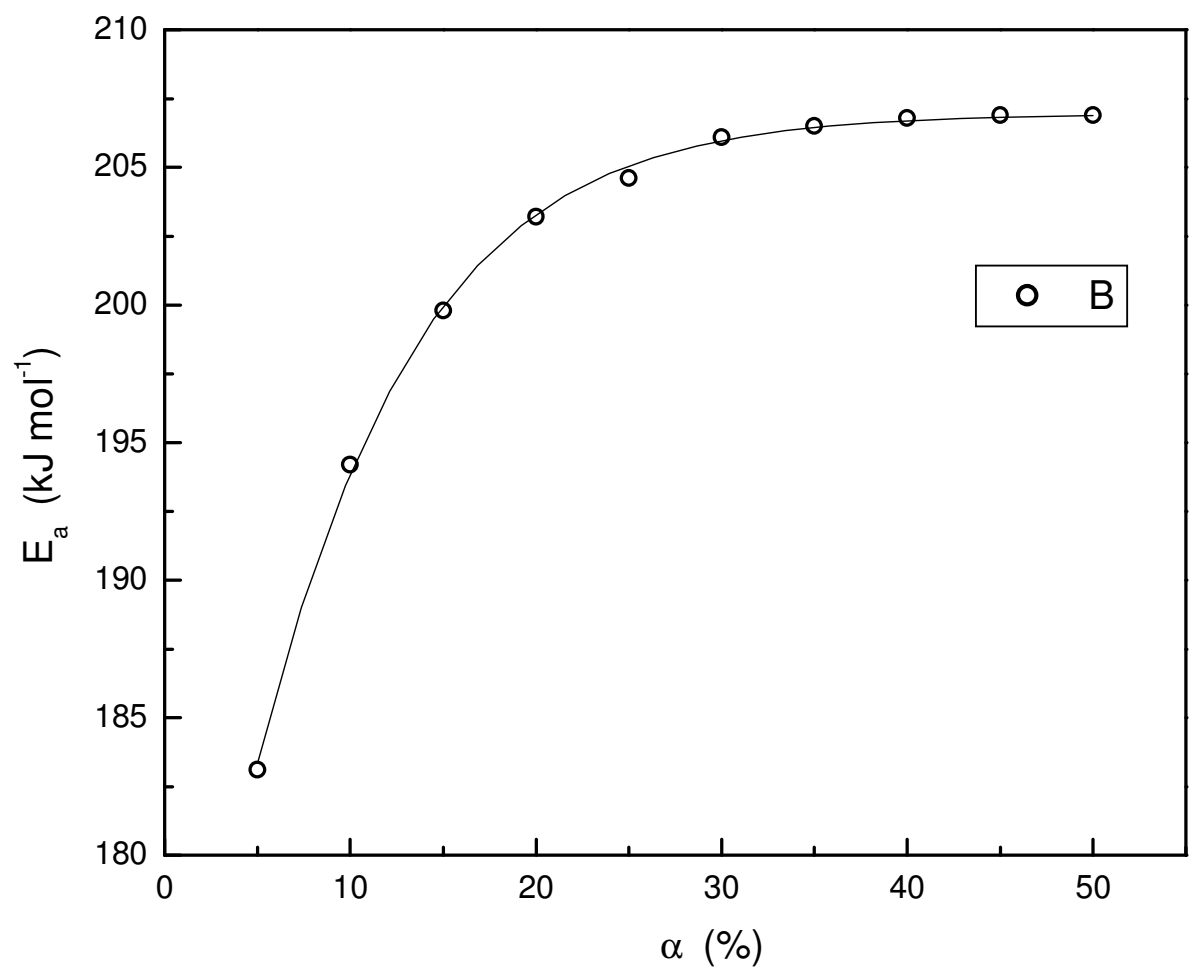

Figura 33. Energia de ativação $\left(E_{a}\right)$ vs fator de conversão $(\alpha)$ apresentados na Tabela 9 para o edulcorante aspartame. 


\subsubsection{Sacarina}

De acordo com os resultados da curva TG, a sacarina ácida apresenta uma volatilização, acompanhada de fusão. Assim, os parâmetros cinéticos se referem a este processo.

As curvas TG para a sacarina $\mathrm{H}$ em diferentes razões de aquecimento são apresentadas na Figura 34, sendo usadas para os cálculos.

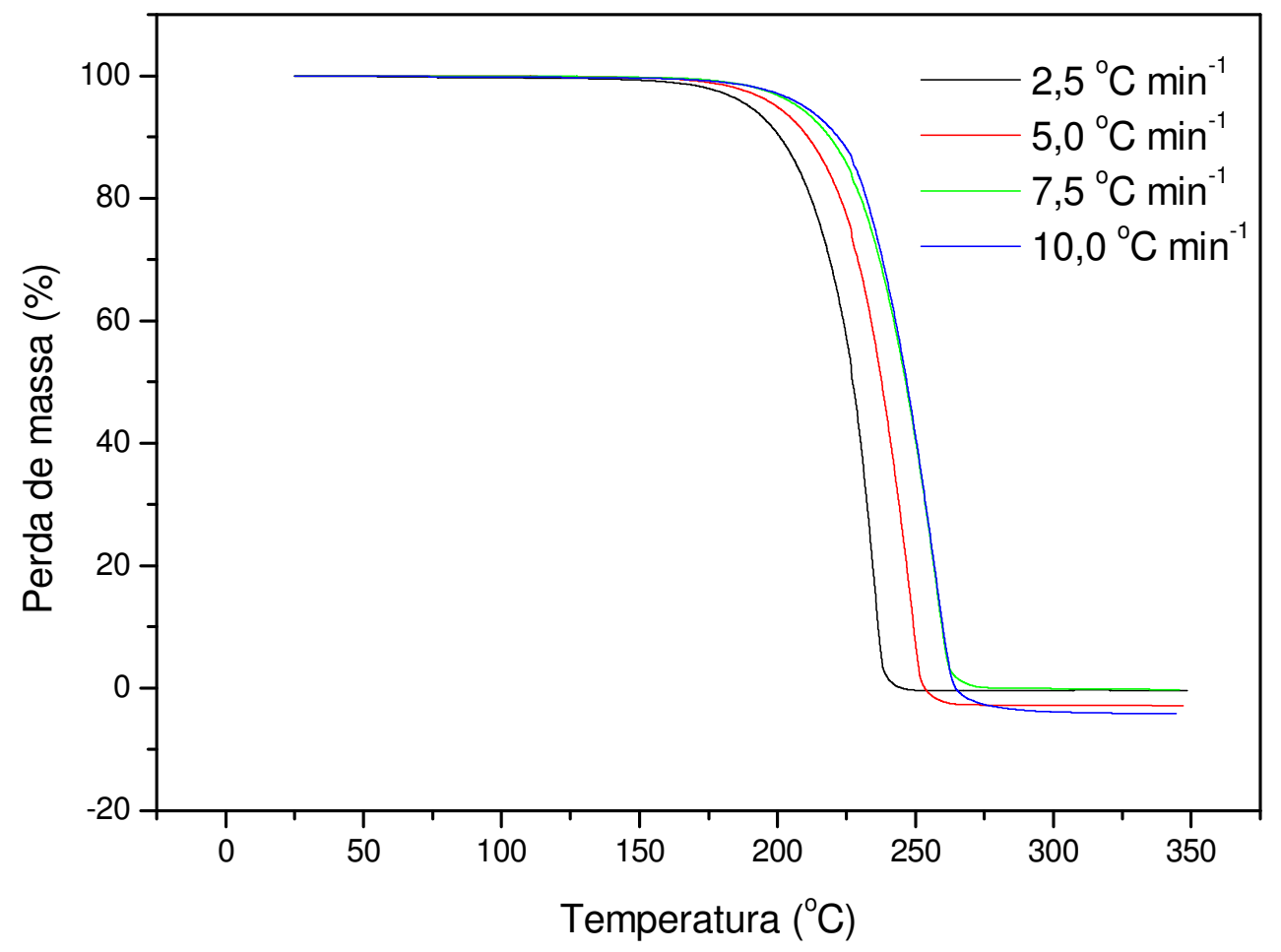

Figura 34. Curvas TG da sacarina H obtidas a várias razões de aquecimento, sob atmosfera de $\mathrm{N}_{2}$, em suporte de alumina.

A relação de $\log \beta$ vs 1/T para a sacarina H são apresentadas na Figura 35 e se mostram paralelas apenas em conversões mais elevadas, evidenciando influência da fusão nas conversões mais baixas. Essa relação permite obter os resultados da Tabela 10, usando-se o programa computacional da TA Instruments. 


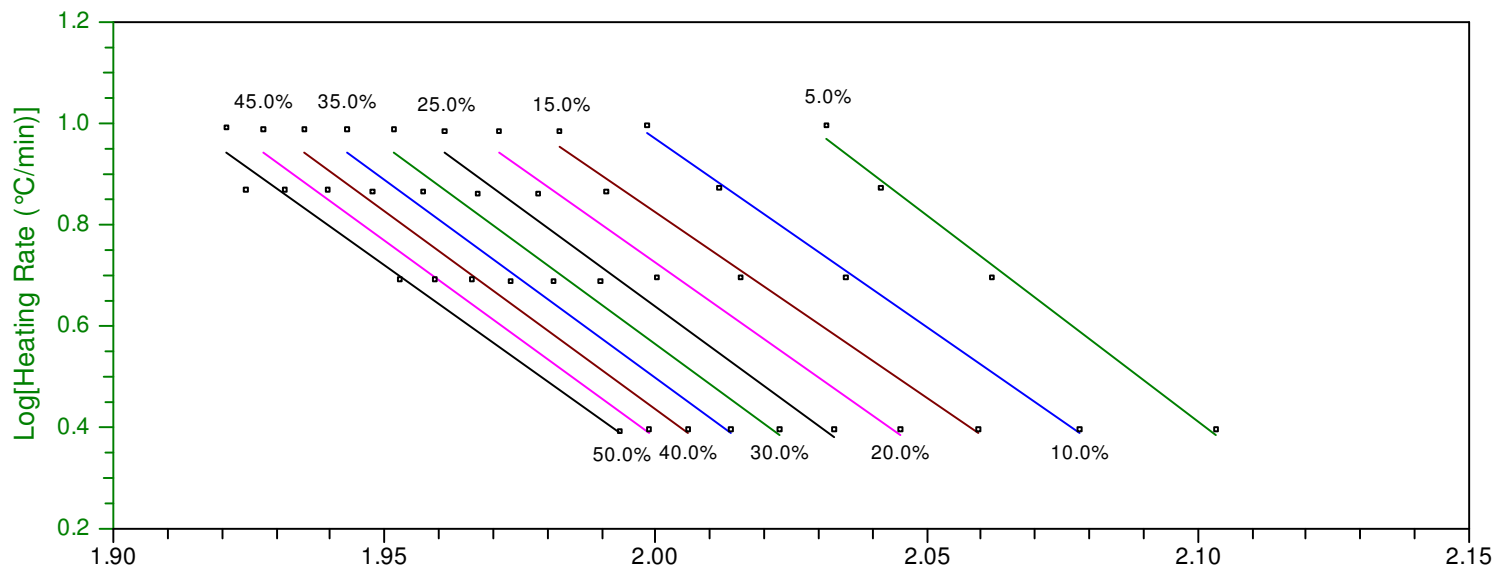

Figura 35. Logaritmo da razão de aquecimento em função do inverso da temperatura para os níveis de decomposição térmica fixados para a sacarina $\mathrm{H}$.

Tabela 10. Parâmetros cinéticos de decomposição térmica da sacarina obtida para cada nível de conversão ( $T_{1 / 2} 60 \mathrm{~min}$ - temperatura para meia vida de 60 minutos)

\begin{tabular}{|c|c|c|c|c|}
\hline Composto & $\begin{array}{c}\text { Conversão } \\
\text { (\%) }\end{array}$ & $\begin{array}{c}\mathrm{E}_{\mathrm{a}} \\
\left(\mathrm{KJ} \mathrm{mol}^{-1}\right)\end{array}$ & $\begin{array}{l}\log A \\
\left(\min ^{-1}\right)\end{array}$ & $\begin{array}{c}T_{1 / 2} 60 \mathrm{~min} \\
\left({ }^{\circ} \mathrm{C}\right)\end{array}$ \\
\hline \multirow{10}{*}{ Sacarina $\mathrm{H}$} & 5,0 & 163,5 & 15,97 & 203,7 \\
\hline & 10,0 & 142,3 & 13,73 & 201,4 \\
\hline & 15,0 & 144,5 & 14,00 & 200,6 \\
\hline & 20,0 & 150,8 & 14,70 & 200,2 \\
\hline & 25,0 & 154,4 & 15,10 & 200,1 \\
\hline & 30,0 & 156,2 & 15,31 & 200,0 \\
\hline & 35,0 & 155,8 & 15,27 & 199,7 \\
\hline & 40,0 & 153,3 & 15,01 & 199,1 \\
\hline & 45,0 & 150,7 & 14,75 & 198,4 \\
\hline & 50,0 & 146,9 & 14,37 & 197,4 \\
\hline
\end{tabular}

Sob estas condições, a temperatura de meia vida no período de 60 minutos com 25,0 a $40,0 \%$ de conversão foi de $199,7{ }^{\circ} \mathrm{C}$. 
A dependência de $E_{a}$ com a é mostrada na Figura 36 e confirma a influência da fusão sugerindo que a formação do material carbonizado discutida na curva TG também afeta na cinética de volatilização.

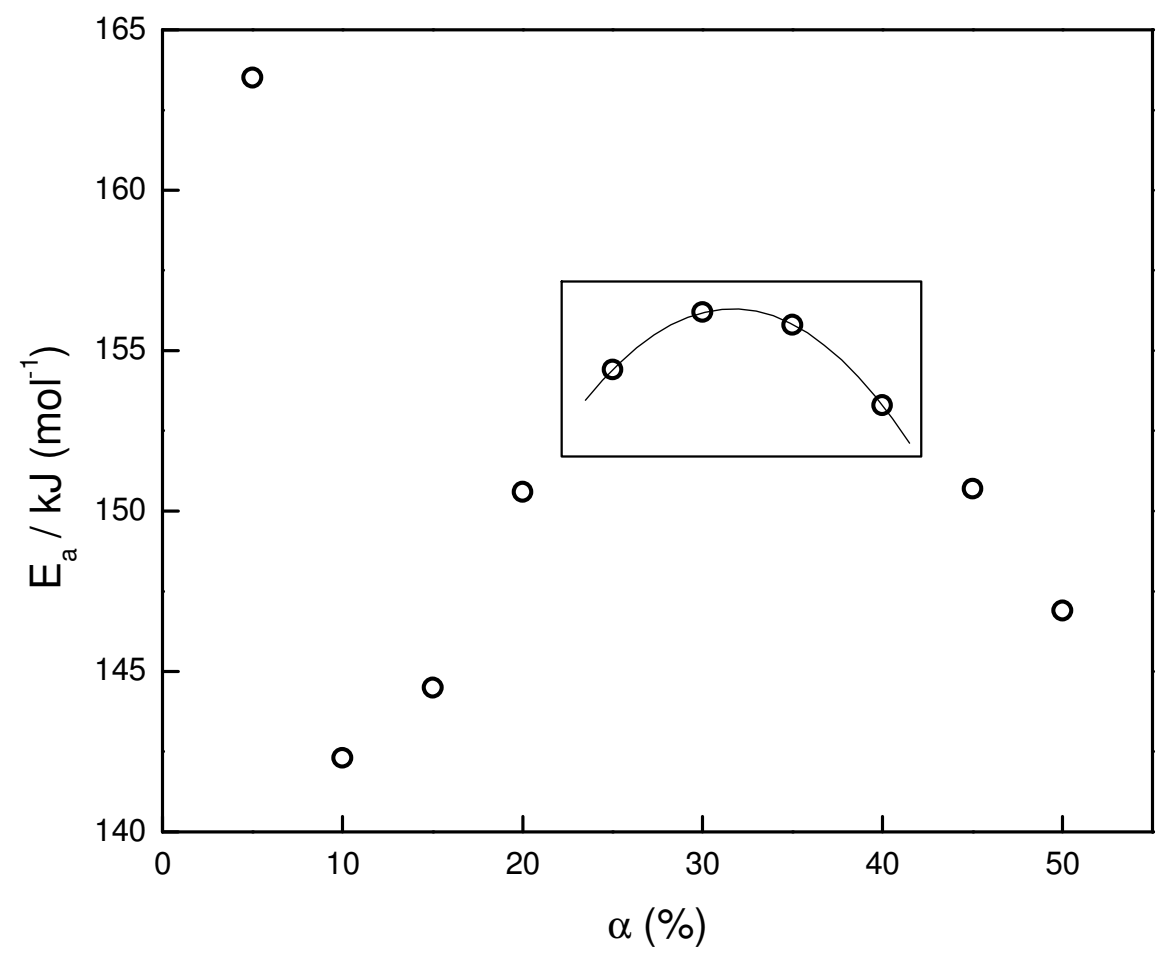

Figura 36. Energia de ativação $\left(E_{a}\right)$ vs fator de conversão $(\alpha)$ apresentados na Tabela 10 para o edulcorante sacarina.

A partir da Figura 36 determinou-se os valores de $E_{a}=154,9 \pm 0,7 \mathrm{KJ} \mathrm{mol}^{-1} \mathrm{e}$ $\log A=15,2 \pm 0,1 \mathrm{~min}^{-1}$, para conversões de 25; 30; 35 e $40 \%$. A escolha destes valores se deu pela correlação polinomial entre os pontos da curva, região em destaque nesta Figura. Com estes pontos há uma correlação exponencial $r=0,99991$. Esta correlação varia significativamente quando os pontos vizinhos são incluídos no cálculo, sugerindo que tanto frações menores, quanto maiores são afetadas pelos eventos térmicos descritos acima. 


\section{CONCLUSÕES}

A recristalização dos compostos comerciais resultou em diferenças espectrais e térmicas pouco significativos, sugerindo grau de pureza relativamente elevado para estes compostos.

Os compostos foram submetidos à análise térmica (TG/DTG e DTA) mostrando decomposição típicos para cada caso, alguns após desidratação. Apresentaram água de hidratação: aspartame (2); esteviosídeo (1) e sacarina sódica (2).

Após desidratação, pode-se afirmar que os edulcorantes apresentaram a seguinte ordem de estabilidade:

esteviosídeo < aspartame < sacarina $\mathrm{Na}<$ ciclamato $\mathrm{Na}<$ acessulfame- $\mathrm{K}$

A sacarina ácida apresentou volatilização sem decomposição.

Os resíduos de decomposição térmica foram sulfato de potássio para o acessulfame-K e sulfato de sódio para a sacarina sódica e ciclamato de sódio.

Os estudos cinéticos de decomposição térmica não puderam ser desenvolvidos para a maioria das amostras estudadas, pois havia sobreposição de eventos. Esse estudo foi realizado com maior segurança apenas para o aspartame após a desidratação e para a sacarina, permitindo calcular as energias de ativação e fator pré-exponencial, para sua decomposição e volatilização, respectivamente. 


\section{REFERÊNCIAS BIBLIOGRÁFICAS}

1. SIMÃO, A.M. Aditivos para alimentos sob o aspecto toxicológico. São Paulo: Nobel, 1985. 231 p.

2. AGÊNCIA NACIONAL DE VIGILÂNCIA SANITÁRIA (ANVISA). Portaria $n=540$ - SVS/MS, de 27 de outubro de 1997. Disponível em: <http://elegis.bvs.br/leisref/public/showAct.php?id=88> acesso em 12abr. 2006.

3. CHEN, Q. C.; WANG, J. Simultaneous determination of artificial sweeteners, preservatives, caffeine, theobromine and theophylline in food and pharmaceutical preparations by ion chromatography. Journal of Chromatography, v. 937, p. 5764, 2001.

4. AGÊNCIA NACIONAL DE VIGILÂNCIA SANITÁRIA (ANVISA). Resolução RDC $n^{\circ} 3$, de 2 de janeiro de 2001. Disponível em:

<http://www.anvisa.gov.br/legis/resol/03 01rdc.htm> acesso em 09fev.2006.

5. NABORS, L. O’B.; GELARDI, R. C. Alternative sweeteners. 2. ed. New York: Marcel Dekker, 1991. $461 \mathrm{p}$.

6. INGLETT, G. E. Sweeteners - a review. Food and Tecnology, v. 35, n. 3, p. 37-41, 1981.

7. OHTMER, D. F. Encyclopedia of Chemical Technology. 3. ed. New York: John Wiley, 1984. p. 448-464.

8. LEHNINGER, A. L. Princípios de Bioquímica. 4. ed. São Paulo: Edgard Blucher, 1980. p. 839.

9. PRISTA, L. N.; ALVES, A. C.; MORGADO, R. M. R. Técnica Farmacêutica e Farmácia Galênica. 3. ed. São Paulo: Fundação Calouste Gulbenkian, 1990. v. 2, p. 805.

10. SIMENCIO, R. L. Potencialidade do uso de tratamentos quimiométricos de dados termogravimétricos: formulação farmacêutica e adoçante artificial. 2005. 95 f. Dissertação (Mestrado em Química Analítica) - Instituto de Química de São Carlos, Universidade de São Paulo, São Carlos, 2005.

11. CANDEBAT, Z. E. V.; ROCHÉ, M. O. G. Acción, uso, análisis y toxicidad de los edulcorantes sintéticos de empleo actual y potencial, em Cuba.

Alimentaria,v. 4, p. 47, 1989.

12. ADA REPORTS: from the association. Position of the American Dietetic Association: use of nutritive and nonnutritive sweeteners. Journal of the American Dietetic Association, v. 104, p. 255-275, 2004. 
13. FATIBELLO-FILHO, O.; VIEIRA. I.C.; GOUVEIA S.T.; CALAFATTI, S.A.; GUARITÁ-SANTOS, A.J.M. Adoçantes artificiais, Química Nova, v. 3, n. 19, p. 248-260. 1996.

14. ICBUDAK, H.; HEREN, Z.; UYANIK, A.; ODABASOGLU, M. Decomposition pathway of diaquabis ( $n, n^{\prime}$-dimethyl-1,2-ethanediamine) $\mathrm{Ni}(\mathrm{II})$ acesulfamate. Journal of Thermal Analysis and Calorimetry, v. 83, p. 303-306, 2005.

15. LIPINSKI, G. W.R. The new intense sweetener acesulfame-K. Food Chemistry, v. 16, p. 259-269, 1985.

16. BIRCH, G. G.; HAYWOOD, K. A.; HANNIFFY, G. G.; COYLE, C. M. Apparent specific volumes and tastes of cyclamates, other sulfamates, saccharins and acesulfame sweeteners. Food Chemistry, v. 84, p. 429-435, 2004.

17. GEUNS, J. M.C. Stevioside. Phytochemistry, v. 64, p. 913-921, 2003.

18. FARMACOPÉIA BRASILEIRA. 4. ed. São Paulo: Atheneu. 2003. fasc. 5, pte 2, p. 233.

19. STEVITA: Qualidade em todas as fases da vida. Produced by stevita@stevita.com.br. Disponível em:

http://stevita.com.br/dossie_frameset.htm>. Acesso em: 12 abr. 2006.

20. ARNOLD, D. L. Toxicology of saccharin. Fundamental and Applied Toxicology, v. 4, p. 674-685, 1984.

21. BERNAL, C.; COUTO, A. B.; BREVIGLIERE, S. T.; CAVALHEIRO, E. T. G. Influência de alguns parâmetros experimentais nos resultados de análises calorimétricas diferenciais - DSC. Química Nova, v. 25, n. 5, p. 849-855, 2002.

22. BEAR, M. F.; CONNORS, B. W.; PARADISO, M. A. Neurociências: desvendando o sistema nervoso. 2. ed. Porto Alegre: Artmed, 2002. 855 p.

23. ANATOMIA e fisiologia humanas: sistema sensorial. Produced by $\operatorname{Prof}^{\mathrm{a}}$ A. L. M. Vilela. Disponível em: http://www.afh.bio.br/sentidos/Sentidos9.asp>. Acesso em: 11 jul. 2006.

24. COGNOSCO: diário das pequena descobertas da vida. Produced by M. Maia. Disponível em: http://cognosco.blogs.sapo.pt/arquivo/1031626.html>. Acesso em: 11 jul.2006.

25. MARZZOCO, A.; TORRES, B. B. Bioquímica Básica. 2. ed. Rio de Janeiro: Guanabara Koogan, 1999. 360 p.

26. HAUACHE, O. M. Receptores acoplados à proteína G: implicações para a fisiologia e doenças endócrinas. Arquivo Brasileiro de Endocrinologia e Metabolismo, v. 45, n. 3, p. 228-239, 2001. 
27. MACKENZIE, R. C. Nomenclature in thermal analysis. Termochimica Acta, v. 28, n. 1, p. 1-6, 1979.

28. MOTHÉ, C. G.; AZEVEDO, A. D. Análise Térmica de Materiais. São Paulo: Editco Comercial Ltda, 2002. v. 1.

29. CAVALHEIRO, E. T. G.; IONASHIRO, M.; BREVIGLIERE, S. T.; MARINO, G.; CHIERICE, G. O. A influência de fatores experimentais nos resultados de análises termogravimétricas. Química Nova, v. 18, n. 3, p. 305-308, 1995.

30. GIOLITO, I. Métodos Eletrométricos e Eletroanalíticos. São Paulo: Multitec, 1980. 273 p.

31. MÁLEK, J. Kinetic analysis of crystallization processes in amorphous materials. Thermochimica Acta, v. 355, n. 1-2, p. 239-253, 2000.

32. SKOOG, D. A.; HOLLER, F. J.; NIEMAN, T. A. Princípios de análise instrumental. Tradução de Ignez Caracelli, Paulo Celso Isolani, Regina Helena de Almeida Santos, Regina Helena Porto Francisco. 5. ed. Porto Alegre: Bookman, 2002. 836 p.

33. SILVERSTAIN, R. M.; BASSLER, G. C.; MORRIL, T. C. Identificação espectrométrica de compostos orgânicos. Tradução de Ricardo Alencastro, Laura Wircker, Rosane San Gil. 5. ed. Rio de Janeiro: LTC, 1994. 387 p.

34. TORRES, C. Avaliação do modelo cinético de decomposição térmica de complexos de titânio, de bário e de estrôncio com ácido esteárico para a produção de BaTiO3, SrTiO3 e (Ba, Sr)TiO3. 2005. 173f. Tese (Doutorado em Química Analítica) - Instituto de Química, Universidade Estadual Paulista Júlio de Mesquita Filho, Araraquara, 2005.

35. GUINESI, L. S. Estudo analítico, termoanalítico e cinético de complexos de estanho-titânio-EDTA como precursores na obtenção de óxidos mistos de $\mathrm{Ti}_{0,90} \mathrm{Sn}_{0,10} \mathrm{O}_{2}$ visando um sensor para gases. 2003. $193 \mathrm{f}$. Tese (Doutorado em Química Analítica) - Instituto de Química, Universidade Estadual Paulista Júlio de Mesquita Filho, Araraquara, 2003.

36. WENDLANT, W. W. Thermal Analysis. 3. ed. New York: Willey, 1986, 810 p.

37. ARAÚJO, A. A. S. Estabilidade térmica, determinação de parâmetros cinéticos, estudo de compatibilidade e avaliação de complexos e inclusões envolvendo o AZT. Exame de Qualificação (Doutorado, Programa de PósGraduação em Fármaco e Medicamentos) - Área de Produção e Controle Farmacêuticos, Universidade de São Paulo - São Paulo, 206 f, 2002.

38. FLYNN, J. H.; WALL, L. A. A quick, direct method for the determination of activation energy from thermogravimetry data. Journal of Polymer Science, Part B: Polymer Physics, v. 4, n. 5, p. 323-328, 1966. 
39. OZAWA, T. Kinetic analysis of derivate curves in thermal analysis. J. Thermal Analysis, v. 2, n. 3, p. 301-324, 1970.

40. CONCEIÇÃO, M. M. Estudo da degradação térmica de adoçante com aspartame. 2004. 133 f. Tese (Doutorado em Química) - Instituto de Química, Universidade Federal da Paraíba, João Pessoa, 2004.

41. CONCEIÇÃO, M. M.; SOUZA, A. G. ; FERNANDES JUNIOR, V J ; NASCIMENTO, T. G. ; ARAGÃO, C F S ; MACEDO, R. O. Study of thermal degradation of aspartame and its products of conversion in sweetener using isothermal thermogravimetry and HPLC. Thermochimica Acta, v. 433, p.163169, 2005.

42. KROYER, G. T. The low calorie sweetener vstevioside: stability and interaction with food ingredients. Lebensm-Wiss u-Tecchnology, v. 32, p. 509512, 1999.

43. ICBUDAK, H.; HEREN, Z.; UYANIK, A.; ODABASOGLU, M. Decomposition pathway of diaquabis ( $n, n^{\prime}$-dimethyl-1,2-ethanediamine) Ni(II) acesulfamate. Journal of Thermal Analysis and Calorimetry, v. 83, p. 303-306, 2005.

44. NAUMOV, P.; JOVANOVSKI, G. Vibrational study of two novel cesium saccharinates. Spectroscopic evidence for organic molecule embedded in ionic salt. Vibrational Spectroscopy, v. 24, n. 2, p. 201-211, 2000.

45. NAUMOV, P.; JOVANOVSKI, G.; ABBRENT, S.; TERGENIUS, L. E. Thermal behavior of the saccharines of $\mathrm{K}^{+}, \mathrm{Na}^{+}, \mathrm{Rb}^{+}, \mathrm{Cs}^{+}$and $\mathrm{NH}_{4}^{+}$: structural inferences. Thermochimica Acta, v. 359, p. 123-130, 2000.

46. FLYNN, J. H.; WALL, L. A. A quick, direct method for the determination of activation energy from thermogravimetry data. Journal Polymer Letters, v. 4, n. 5, p. 323, 1966.

47. OZAWA, T. A new method of analyzing thermogravimetric data, Bulletin of the Chemical Society of Japan, v. 38, n. 11, p. 1881-1886, 1965.

48. BROWN, M. E.; MACIEJEWSKI, M.; VYAZOVKIN, S.; NOMEN, R.; SEMPERE, J.; BURNHAM, A.; OPFERMANN, J.; STREY, R.; ANDERSON, H. L.; KEMMLER, A.; KEULEERSH, R.; JANSSENSH, J.; DESSEYNH, H.O.; LII, CHAO-RUI; TANGI, TONG B.; RODUITJ, B.; MALEKK, J.; MITSUHASHI, T. Computacional aspects of kinetic analysis Parts A, B, C, D e E. Thermochimica Acta, v. 355, p. 125-180, 2000.

49. POUCHERT, C. J. The Aldrich Library of FT-IR Spectra. Milwaukee, Wisconsin, USA: Aldrich Chemical Company, 1985. v. 2. 
50. INTEGRATED Spectral Database System of Organic Compounds. In: Scifinder Scholar. Washington: American Chemical Society, 2006. Software.

51. SEGATO, M. P. Estudos termoanalíticos do ácido algínico e dos alginatos de metais alcalinos, alcalino-terrosos, amônio, mono-, di- e trietanolamônio. 2006. 112 f. Dissertação (Mestrado em Química Analítica) Instituto de Química de São Carlos, Universidade de São Paulo, São Carlos, 2006. 